\title{
Disentangling Social Capital: Lab-in-the-Field Evidence on Coordination, Networks and Cooperation
}

\author{
Sandra Polania-Reyes \\ University College London, Corpovisionarios and University of Siena ${ }^{1}$
}

This version: January 25, 2016

For the last version please click here

PLEASE DON'T CITE

\begin{abstract}
Although social capital has been considered of the utmost importance for development it remains a complex and elusive concept. Different dimensions of social capital form part of the puzzle: cooperation is an individual other-regarding preference; social norms stem from beliefs about others' behavior; and the formation of such beliefs is mediated by attributes of the social network.

To disentangle social capital we conduct an artefactual field experiment with 714 households at the inset of a Conditional Cash Transfer program in an urban context. To our knowledge this is the first paper that disentangles cooperation from coordination by conducting a minimum effort coordination game with Pareto ranked equilibria. Willingness to cooperate is teased out using a public goods game. By controlling for the density of network information we capture the role of connections, which is the third element of the mixture. We also look at the relation between our experimental data and traditional survey measures of social capital.
\end{abstract}

Our identification strategy allows us to assess whether exposure to the program could be helping individuals overcome strategic uncertainty and select the most efficient equilibrium in the coordination game. The regressions suggest that the program helps overcome the coordination failure through different channels. In particular, the evidence suggests there is a spillover effect of the monetary incentive as it facilitates a social norm, which itself allows individuals to overcome the coordination failure. We rule out confounding factors such as individual socio-economic characteristics, social capital accumulation, willingness to cooperate and connectivity.

JEL Codes: C92 (Experiments Laboratory, Group Behavior), D70 (Analysis of Collective DecisionMaking); D78 (Policy making and implementation); H41 (Public goods); Z13 (Social norms and social capital)

Keywords: lab in the field experiments, coordination, social preferences, social capital, conditional cash transfer programs, cooperation, social networks

1 Email:s.polania@corpovisionarios.org 


\section{Disentangling Social Capital}

Social policies may improve economic outcomes through changes in the structures of social relationships. Social capital refers to the set of resources inherent to those relationships and their structure within a community (Uphoff 2001). It can be understood in terms of social norms and networks (Putnam et al. 1993; James Samuel Coleman 1994) and manifests itself through patterns of pro-social behavior or prosocial preferences (trust, reciprocity, and cooperation) (Christoforou and Davis 2014).

Three elements lie at the core of social capital (James Samuel Coleman 1987; James S. Coleman 1988): coordination, cooperation and networks ${ }^{2}$. Coordination and the social network determine the effectiveness of the social norms, as coordination reflects the ability to exploit Pareto-improving opportunities in the presence of uncertainty and the features of the social network provide the environment in which that ability is likely to emerge. The third element at the heart of social capital is the ability to overcome free-riding incentives in real-world situations (James S. Coleman 1988). These situations, especially salient among poor communities, share the same game-theoretic representation of a public goods game: in the process of building social capital, cooperative outcomes are subject to "freeriding"3 incentives (James Samuel Coleman 1994).

The ability to solve cooperation and coordination problems by a community is key in many developing countries where weak institutions and a weak rule of law are prevalent. In particular, coordination on efficient outcomes is key to solve collective action problems and market failures thus bring economic development, build efficient institutions and avoid conflict (James Samuel Coleman 1987; Matsuyama 1997; Hoff 2000; Rousseau 2000; Hoff and Stiglitz 2001; Bowles 2004; McAdams 2008) as well as promote entrepreneurship (Adler and Kwon 2002).

Despite its importance for development and growth, and after a boom of the literature of social capital in development economics (Woolcock 1998; Woolcock and Narayan 2000; Fukuyama 2001), social capital is still considered an elusive concept (Adler and Kwon 2002; Brunie 2009) ${ }^{4}$. There is still debate on the validity of the survey measures and other qualitative measures to capture different dimensions of social capital (Portes and Landolt 2000; Narayan and Cassidy 2001; Putnam 2001b, 2001a; Kawachi et al. 2008). In contrast to survey measures, choice experiments are incentivized, involve real

\footnotetext{
${ }^{2}$ In their seminal work, Putnam et al. (1993):167 define social capital as those "features of social organization, such as trust, norms, and networks that can improve the efficiency of society by facilitating coordinated actions" (emphasis added). James S. Coleman (1988) was clear enough to define social capital by its function: "It is not a single entity but a variety of different entities, with two elements in common: they all consist of some aspect of social structures, and they facilitate certain actions of actors within the structure" (p. S98).

${ }^{3}$ See Samuelson (1954); Grossman and Hart (1980); Ostrom (1998); Olson (2009). Evidence on social program evaluations supports this claim (Adato et al. 2005; Fearon et al. 2009; Avdeenko and Gilligan 2014).

${ }^{4}$ For example, in contrast to the structural (or functional) approach of social capital by Coleman (1988) and Putnam (1990), Fukuyama (2001) defines social capital as "an instantiated informal norm that promotes cooperation between two or more individuals". This paper also aims to contribute to settle this disagreement.
} 
behavior and eliminate sources of heterogeneity that may confound estimation of preferences from life choices.

The use of 'lab in the field' experiments as a method to study social preferences within a community and to measure social capital is not new ${ }^{5}$. Public good and trust games have been used in a variety of different situations, both urban and rural $^{6}$. This is not the case for coordination games ${ }^{7}$. The main contribution of this study is the use of a new experimental measure of social capital based on the behavior in a coordination game with social networks. We also use a Public Goods (PG) game and traditional survey measures of social capital. This is the first study focused on behavior in these two games to disentangle beliefs from social preferences.

Any given form of social capital that helps to coordinate and achieve more efficient outcomes improves wellbeing and is thus highly valuable to the community. Conditional Cash Transfers (CCT) programs have become one of the most popular interventions in developing countries. There is a strong line of research showing that CCTs are successful in their goals (i.e. nutrition, education and health). It turns out most CCTs have a component of new interactions among the beneficiaries within the communities that should lead to building or strengthening social ties (Putnam 1995)and enforcing prosocial norms. Though this makes CCT a natural policy intervention to study social capital accumulation, the literature remains sparse in that sense ${ }^{8}$. Yet the design of CCT programs originally included a strong 'social capital' component, making such analysis all the more relevant.

We conduct an artefactual field experiment ${ }^{9}$ and combine experimental and non-experimental data to study the role of networks, leadership, other-regarding preferences and communication in the ability to coordinate in the context of a CCT program in a developing country. We examine the relation between the exposure to the program, behavior in the games, individual network information and traditional measures of social capital.

We observe that the length of exposure of the beneficiary to the program matters. We find a large and significant relationship between an individual's exposure to the program and their ability to coordinate: longer exposure is positively correlated with choosing the Pareto-dominant equilibrium in our coordination game. The association remains robust to controlling for confounding effects such as wealth, other-regarding preferences and the group's network. The degree of the participant in the network is

\footnotetext{
${ }^{5}$ Carpenter (2002); Carpenter et al. (2004); Gaechter et al. (2004); Karlan (2005); Cardenas et al. (2009); Fearon et al. (2009); Voors et al. (2012); Gilligan et al. (2014).

${ }^{6}$ Our Public Good game design has been used extensively in Colombia (Attanasio et al. 2009; Cardenas et al. 2013; Attanasio et al. 2015) and in other countries (Cardenas et al. 2013; Barr et al. 2014).

${ }^{7}$ Using coordination games as instruments to identify social norms is very recent (Krupka and Weber 2013; Erkut et al. 2015).

${ }^{8}$ For rigorous studies on whether CCTs affect social capital see Attanasio et al. (2015).

${ }^{9}$ According to Harrison and List (2004) taxonomy of field experiments.
} 
positively related to the ability to coordinate. We find also a weak and positive relation between willingness to cooperate and the ability to coordinate.

Our paper contributes in several ways to a recent stream of research combining survey and experimental measures of social capital. First, to our knowledge this is the first study that implements an n-person coordination game with more than two ranked equilibria in the field in order to measure the presence of a social norm as the beliefs. Our game design aims to be a better adaptation to the field of the coordination problem. Agents must coordinate on a common action with the group's success depending on the least favorable action of a team member. The minimum effort game is an adaptation of the stag hunt game ${ }^{10}$ (Holt 2007) with multiple choices and subjects. This is a more realistic design if we want to examine how groups of more than two people coordinate and use a social norm to reach the most efficient outcome.

Brooks et al. (2015) is the only other study so far that uses a coordination game in the field to study cooperation and coordination. They conducted a stag hunt game to examine the role of culture on the efficiency of coordination among men from different castes in India ${ }^{11}$. Our study differs in several ways with theirs. First, although their design is a useful abstraction of the ability to coordinate in the textbook, most of interactions in the field are n-participants and usually within a broader set of options. We use an eight-player-three choices coordination game with three ranked equilibria. Second, Brooks et al. (2015) is indeed the first study on culture and coordination efficiency in the field and ours is the first one looking at our design as a potential measure of effectiveness of social norms in the field. Third, we do exploit the role of social networks on coordination. Fourth, though culturally diverse their sample is small and composed of only men. Our sample is larger, heterogeneous in a wide range of socioeconomic variables and focused on the poorest of the poor.

Second, we relate trust to cooperative behavior as other-regarding preferences whereas the literature has to a large extent focused on behavior in experimental trust games (For an extensive review see Thoni et al. (2012). Third, by combining survey measures, network information and experimental data, we not only look to shed light on the behavioral validity of such measures but also to clarify in the debate multifaceted nature of social capital (Dasgupta and Serageldin 2001; Brunie 2009) and how different dimensions of social capital can be considered in empirical analysis.

\footnotetext{
${ }^{10}$ The stag hunt game is a two-player, two-choice coordination game with a payoff-dominant equilibrium and a riskdominant one.

${ }^{11}$ For a very similar experimental design in India, see also Chakravarty et al. (2015). Boschini et al. (2014) examined gender-based focal points or conventions by using a battle of the sexes game (i.e. a coordination game with multiple equilibria but the equally efficient and different allocations) and use a random sample of Swedish citizens. Bosworth (2013) also uses a Stag Hunt game in the lab as a measure of social capital, and find that traditional survey measures of trust is related to behavior in the experiment with 20 students. This positive relation is consistent with the findings of L. R. Anderson et al. (2004) and Thoni et al. (2012) on a Public Goods game and using students and a random sample from the Danish population, in the lab and online, respectively.
} 
Fourth, despite the extensive experimental literature on coordination in the lab, evidence on coordination in the field is almost nonexistent and there is no evidence on coordination within a policy intervention or with policy implications. Most of the literature focuses on the structure of the coordination game and how it is possible to achieve efficiency (i.e. learning, social networks, monetary incentives). This paper is the first that uses a coordination game to measure social norms within a CCT framework and our results are confirm the importance of the social component of these interventions at the community level ${ }^{12}$.

Finally, this study also contributes to the small but growing literature that conduct behavioral experiments with real-world leaders in a natural field setting (Attanasio et al. 2015; Jack and Recalde 2015; Kosfeld and Rustagi 2015; Polania-Reyes 2016).

The rest of the paper is organized as follows. Sections 2 and 3 explain how the behavioral experiments measuring coordination and cooperation are useful to disentangle social capital. Section 4 examines the role of networks on collective action and offers a brief introduction to the institutional setting of the CCT. Section 5 describes the Public Goods game. Section 6 experimental setting and data on group performance and group and individual characteristics. Section 7 quantifies the relation between the CCT and the ability to coordinate while accounting for confounding factors such as wealth, otherregarding preferences, network information and socio-economic environment. Finally, Section 8 offers concluding remarks.

\section{Measuring a Social Norm with a Coordination game}

Collective action may facilitate coordination in a strategic environment with multiple Pareto-ranked equilibria (see for example, Bryant (1983); Hirshleifer (1983). ${ }^{13}$ In order to examine equilibrium selection in the presence of collective action (Harsanyi and Selten 1988), we consider a very well-known game in the literature. The minimum effort coordination game introduces a conflict between payoff dominance and risk dominance ${ }^{14}$. An individual's payoff depends on her own effort as well as on the minimum effort of the group. The higher the minimal effort, the higher every member's payoff is. In contrast to social dilemma games (e.g., PG games), any common effort level chosen by all group members is an

\footnotetext{
${ }^{12}$ This study is among the pioneers on social norms measurement literature. Mackie et al. (2015) examine about 200 publications on social norms and development; only 14\% discuss norms-measurement methods, most of them on qualitative data and none of them on expectations.

${ }^{13}$ Harsanyi and Selten (1988) present payoff dominance as based on collective rather than on individual rationality. However, most theoretical work on equilibrium selection in coordination games concerns 2x2 games (Harsanyi and Selten 1988; Carlsson and Van Damme 1993; Kandori et al. 1993; H. Peyton Young 1993; S. P. Anderson et al. 2001).

${ }^{14}$ Notion introduced by Harsanyi and Selten (1988). This game is also called the weakest-link game. Many economic and organizational contexts feature situations where the worst component of a product or process determines its overall quality (Camerer and Knez 1994; Foss 2001).
} 
equilibrium, so it is in no one's interest to deviate upward or downward from the common effort. Hence choosing the most efficient (i.e., payoff-dominant) equilibrium is a problem of coordination rather than one of cooperation.

One important coordination device is found in social norms, which arise as an equilibrium selection criterion (Schelling 1960; Horwitz 1990; Kandori et al. 1993) ${ }^{15}$. Social norms are now proposed by theory of law as efficient alternatives to solve collective action problems as they internalize negative externalities and provide signaling mechanisms (Ellickson 1991; McAdams 1997; Posner 2002). A social norm is a pattern of behavior such that individuals prefer to conform to it on the condition that they believe that most people in their reference network i) conform to it (i.e. empirical expectations) ${ }^{16}$ and ii) think they ought conform to the norm (i.e. normative expectations) (Bicchieri 2005, 2014) ${ }^{17}$. Given that decisions are private and individual in the ME game, the game is able to capture empirical expectations when all players coincide in any equilibrium and normative expectations when all players coincide in the equilibrium that is best for the group. The combined force of normative and empirical expectations makes norm compliance a superior choice and makes defection, in case the others are expected to cooperate, a bad choice indeed, be it because punishment may follow, or just because one recognizes the legitimacy of other's expectations (Sugden 2000).

Related literature in other social sciences undervalues the potential of coordination games to capture social norms (Bicchieri and Muldoon 2014). However, our particular ME game and our quasi experimental approach in measuring the effect of the exposure to the CCT allow us to indicate how the Pareto-dominant and risk dominant equilibria are attained and how expectations -built via the CCT, become self-fulfilling.

Empirical expectations are key for social norms to evolve and they are mostly based on observations of what individuals in the reference group have done in the past (Bicchieri 2014). In addition, in repeated encounters, people have an opportunity to learn from each other's behavior, and to secure a pattern of reciprocity that minimizes the likelihood of misperception ${ }^{18}$. On the other hand, communication is key in making efficient coordination a focal point (Blume and Ortmann 2007; Choi and

\footnotetext{
15 This game-theoretical approach of social norms introduces them as customary rules of behavior that coordinate our interactions with others. Once a particular way of doing things becomes established as a rule, it continues in force because we prefer to conform to the rule given the expectation that others are going to conform (Schelling 1960; Lewis 1969; H Peyton Young 2008).

${ }^{16}$ The definition of the coordinative role of institutions and practices of society is similar to Gauthier (1986)'s: "An institution or practice is coordinative if each person prefers to conform to it provided (most) others do, but prefers not to conform to it provided (most) others do not" (in Jeske and Fumerton (2011): 81).

${ }^{17}$ These are conceptually equivalent to descriptive norm and injunctive norm in psychology (Cialdini and Trost 1998; Fishbein and Ajzen 2011).

${ }^{18}$ This is defined as Common Knowledge by the literature of team reasoning (Sugden 2003).
} 
Lee 2014) ${ }^{19}$. The CCT program may have allowed these observations occur in the community and time of exposure to the program provides the time frame that beneficiaries need to be able to see the benefits of overcoming coordination failures. This is consistent with the hypothesis that social norms emerge in small, groups in which people have ongoing interactions with each other (Hardin 1982; Axelrod 1986; Bicchieri 1993). The CCT program may have also provided a normative framework that changed as well normative expectations.

In order to exist a social norm needs people who collectively believe it exist and also trust that all people believe that everyone should obey that norm. Hence, a social norm that helps a group to overcome a coordination failure exists when individual beliefs coincide, which in our game will be made evident by observing the highest level of effort. If individuals choose the payoff-dominant strategy in a one-shot minimum effort game in a group of more than two players, we would be able to interpret their decision as a belief that the others will choose that strategy, and hence that the group holds the same belief ${ }^{20}$.

This particular coordination game has been used extensively in the $1 a b^{21}$. In fact, experimental evidence supports the prediction that a risk-dominant equilibrium will be favored over the Paretodominant equilibrium - i.e. a coordination failure (Van Huyck et al. 1990; S. P. Anderson et al. 2001; Camerer 2003) unless there is a social norm or institution that re-directs behavior (Bowles 2004) ${ }^{22}$. In the presence of strategic uncertainty, the risk associated with not knowing how your opponent will play the game, risk dominance may yield an individually rational outcome that is not efficient but safe. However, payoff dominance will guarantee a collectively rational and efficient outcome. Then, we would expect that a group rich in social capital is more likely to coordinate on the efficient outcome. Since communication and interactions make coordination possible, in the field we are able to examine the role of the individuals in the group, their interaction history, the members of his/her group and their social

\footnotetext{
${ }^{19}$ Although there is experimental evidence that shows otherwise (Clark et al. 2001; Burton et al. 2005).

${ }^{20}$ This is different from focal points or conventions (Schelling 1960; Lewis 1969; H. Peyton Young 1993; Sugden 1995), a descriptive norm in which only empirical expectations are relevant -people don't expect others to respond if they stray from the convention. Conventions could be measured with a coordination game with multiple equilibria but equally efficient and different allocations e.g. battle of the sexes game. Lewis $(1969: 89,95)$ treats the Pareto dominant equilibrium as the social contract that is not a convention.

${ }^{21}$ See Cooper (1999); Portes and Landolt (2000); Devetag and Ortmann (2007) for surveys on payoff-asymmetric coordination games in the lab.

${ }^{22}$ Among the determinants of achieving the payoff-dominant equilibrium there is evidence in the lab on group size and cost of effort (Van Huyck et al. 1990, 1991), number of interactions (Berninghaus and Ehrhart 1998; Knez and Camerer 2000; Parkhurst et al. 2004), randomness in matching (Keser et al. 1998; Schmidt et al. 2003; Goeree and Holt 2005), information about other player's actions (Berninghaus and Ehrhart 2001; Weber 2006), leadership (Brandts and Cooper 2007; Brandts et al. 2007; Gillet et al. 2011; Cartwright et al. 2013), advice (Brandts and MacLeod 1995; Kuang et al. 2007), monetary incentives (Goeree and Holt 2005; Brandts and Cooper 2006; Brandts and Cooper 2007), action set (Van Huyck et al. 2007), non-monetary incentives (Van Huyck et al. 1997; Bornstein et al. 2002; Blume and Ortmann 2007; Rhodes and Wilson 2008; Dugar 2010; Cason et al. 2012), subject-pool characteristics (Dufwenberg and Gneezy 2005; Engelmann and Normann 2010; Y. Chen et al. 2014; Stoddard and Leibbrandt 2014).
} 
skills when coordinating and hence, solving collective action problems.

In section $\mathrm{v}$ in the appendix we use a Quantal Response non-Equilibrium approach and estimate a structural choice model of the individual decision to coordinate with our data and relate beliefs with exposure to the CCT program and the ability to select the most efficient equilibrium and overcome the coordination failure.

\section{i. $\quad$ Our ME game}

As an experimental design, consider an adaptation of Van Huyck et al. (1990) and the following values of parameters: $n=8$ (eight players), $E=3$ (three choices). Then the payoffs can be described by the matrix presented in Table 1 below. Players simultaneously determine their level of effort $e_{i} \in\{1,2,3\}$. The payoff of player $i$ is determined by the minimum level of effort in the group minus the cost of effort he incurs

$$
\pi_{i}^{M E}=\pi\left(e_{i}, e_{-i}\right)=3\left(1+e_{[1]}-\frac{2}{3} e_{i}\right)
$$

where $\mathrm{e}_{[1]}=\min \left\{\mathrm{e}_{1}, \ldots, \mathrm{e}_{\mathrm{n}}\right\}$ and $\mathrm{e}_{-\mathrm{i}}$ is the $(n-1) x 1-7 \mathrm{x} 1$, vector containing the other players' effort levels.

Table 1. Coordination game. Payoffs table*.

\begin{tabular}{ll|ccc}
\hline & & Minimum Effort Level chosen in the group \\
& & 3 & 2 & 1 \\
\hline \multirow{3}{*}{ My decision } & 3 & $\$ 6$ & $\$ 3$ & $\$ 0$ \\
(effort level) & 2 & & $\$ 5$ & $\$ 2$ \\
& 1 & & & $\$ 4$ \\
\hline
\end{tabular}

*Values are in thousands of Colombian pesos

Any common level of efforts $e_{1}=\ldots=e_{n}$ is a Nash equilibrium, and such equilibria are Paretoranked. In the presence of strategic uncertainty, risk dominance may yield an individually rational outcome that is not efficient but safe. However, payoff dominance will guarantee a collectively rational and efficient outcome. Given the strategic uncertainty, individual $i$ maximizes the expected utility of his payoff in the game.

There are three Nash equilibria in this game and only the belief about other's choosing a certain level of effort will motivate the individual to exert that level of effort. This game shows the tension between payoff dominance and a secure and inefficient equilibrium. The only problem faced by the players is to coordinate in either one of the three Nash equilibria. Since the most efficient equilibrium Pareto superior (i.e. to exert the highest effort level), it is reasonable to assume that players would prefer that outcome. However, choosing the highest level is still risky since if for some reason the other player defects, others are left with the lowest possible payoff. Hence, if there is uncertainty of the other player's 
action it might be better to defect.

We confirm this negative externality occurs in this particular coordination game when we compare the average individual payoffs of the players who chose the lowest level of effort (\$4) with the average payoffs of those who chose the highest (\$2.4) and medium level of effort (\$2.8), both differences being significant at $1 \%$. Comparing the payoffs of choosing the medium level with and the high level, those who chose the medium level of effort had higher payoffs than those who chose the highest level of effort (difference of 0.34 , significant at $10 \%)^{23}$.

\section{Network Information and the Environment: a CCT Program}

There are many advantages of social networks in community life, from exchange of goods and services to the transmission of information, values and norms (Matthew O Jackson 2008) Networks are also important on effort individual decisions (Matthew O Jackson 2010; List and Rasul 2011) and the references therein for studies that use field experiments in combination with social network data). For example, friends may conform to a social norm and status may be a determinant of individual behavior (Bernheim 1994), individuals may be averse to inequality within the network (Fehr and Schmidt 1999; Charness and Rabin 2002).

Network structure becomes an important factor to take into consideration when overcoming collective action problems and constitute a key component of social capital's definition and measurement. The structure of the network, the position of individuals in and their degree it determine, to a great extent, if collective action is successful or not (Gould 1993; Matthew O Jackson and Watts 2002; Matthew O. Jackson et al. 2012) ${ }^{24}$.

There is a wealth of theoretical work supported by extensive evidence in that lab on the coordination problem of collective action on costly links and how information in the structure of the network affects individual's decision to coordinate. However, there is no evidence from the field on how the network attributes of each individual (e.g. number of people known, family ties) explains individual effort decision in situations problems where individuals do not have a single action that constitutes a dominant strategy. To our knowledge this is the first study that looks at the relationship between individuals' features and their decision to coordinate. This would shed light in understanding the determinants of coordination in the field.

\footnotetext{
${ }^{23}$ Choosing the lowest level of effort implied lower payoffs for those who did conform to the 'efficiency' norm. By contrast, the average payoffs of the groups who did conform to 'efficiency' social norm (i.e. all members in the group chose the highest level) was significantly larger (\$6, by construction) than the individual payoffs of the groups in which the minimum effort was medium $(\$ 3.4)$ or low $(\$ 1.9)$, so conforming to the social norm had benefits to everyone.

${ }^{24}$ For evidence of the structure of the social network and coordination games in the lab see Goyal and VegaRedondo (2005); Cassar (2007); Matthew O Jackson (2008); Charness et al. (2014); Choi and Lee (2014).
} 


\section{i. $\quad$ Group allocation using social network data}

In our experiment, each player was asked about her relation with all the other players, where the options given were: (a) relative, (b) friend, (c) acquaintance or (d) unknown. In addition, we also asked for every known person whether the player considered that person to be trustworthy. We also asked the player to choose who would be considered as a leader in the community within the session. For every session, we are able to construct a relationship matrix that describes the shape of existing networks among players $^{25}$. Let $R=\left(r_{i j}\right)_{i, j=1, ., N}$ be an $N x N$ matrix of self-reported connectivity among players in a session of $N$ participants, $x_{k}=\left(x_{k i}\right)_{i=1, \ldots, N}$ an $N x 1$ vector with binary elements $x_{k i}=1$ if player $i$ belongs to group $k$ or 0 otherwise. We chose $\left(x_{k}\right)_{k=A, B, C}$ to maximize $Z_{A}-Z_{C}$ subject to

$$
\begin{gathered}
Z_{A}=x_{A}^{\prime} R x_{A} \\
Z_{C}=x_{C}^{\prime} R x_{C} \\
\sum_{i} x_{k i}=8 \text { for } k=A, C \\
\sum_{k=A, B, C} x_{k i}=1 \text { for each } i=1, \ldots, N
\end{gathered}
$$

With the self-reported data on network connectivity within the session, we built a connectivity index for every player, given by whom the individual is acquainted with, the type of relationship and whether the individual considers the other person trustworthy: 3 points for each friend and relative, 2 points for each trustworthy acquaintances and 1 point for each untrustworthy acquaintances. ${ }^{26} \mathrm{We}$ ordered the individual's score and allocated the participants into three different groups: group A, with the first eight participants with the highest score, the most connected individuals; group $\mathrm{C}$, with the last eight participants with the lowest score, the least connected and group B, the remaining players ${ }^{27}$.

\section{The Conditional Cash Transfer program: Familias en Acción}

Familias en Acción is a CCT that was inspired by the Mexican CCT PROGRESA and whose goal was to reduce extreme poverty in the medium term by providing resources to improve the nutritional status of poor households and in particular their children as well as school enrolment ${ }^{28}$. To get access to the program's grants, beneficiary households have to comply with a number of requirements. FA has three components: a nutritional and health component aimed at households with children less than five, an

\footnotetext{
${ }^{25}$ The fact that the network structure is not randomized but endogenous to the experiment is also a novelty in the literature of coordination and networks.

${ }^{26}$ The performance of the index was robust to different specifications.

${ }^{27}$ The size of group B varied according to the size of the session. The average size of group B was 8.7 (s.d. 0.73).

${ }^{28}$ The program has become the flagship of the Colombian government's social policy as it targets the poorest $20 \%$ of Colombian households. It started in 2002 in 627 small rural areas and in 2007 was expanded to all urban areas in order to include 1.5 million beneficiary households. This CCT is targeted to women, like every other CCT in Latin America.
} 
education grant for children in primary school and an education grant for children in secondary school and a social component, articulated around periodic meetings of beneficiaries ${ }^{29}$, called Care follow-up Meetings (EC) [Encuentros de Cuidado] ${ }^{30}$. The health and nutrition grant, roughly equal to US\$25 independent of family size, is conditioned on attending regularly growth and development check-ups for children, a vaccination program and some 'classes' on hygiene, diet and contraception. The educational grants, aimed at households with children aged seven to seventeen, are conditional on enrolment and regular attendance in school. Each child in primary (secondary) school entitles the household to about US\$8 (US\$16) per month. Households receive a total transfer which may oscillates between $10 \%$ and $21 \%$ of the minimum wage and between $25 \%$ and $50 \%$ of the average level income of the poor (DNP 2010; MESEP 2012) $)^{31}$.

Although participation to the EC meetings is not compulsory to receive the transfer, most beneficiaries (95.94\% in our sample) participate in the EC where, in addition to discussing hygiene, nutrition or other health-specific issues, they have the possibility to discuss a topic or simply chat. Beneficiaries are invited to attend the meetings, which are introduced as key for human capital investment. Conversations with program's officials and with beneficiary mothers indicate that these social aspects are indeed an important feature of the program: beneficiary mothers discuss any aspect related to the community, and by doing so they reach a common ground to make decisions and take actions aimed at improving their life conditions. They start new activities, get to know each other better and improve their ability to act as a group.

Additionally, the beneficiaries elect a representative, called Mother Leader [Madre Líder] (ML) who is in charge of communication with the local office and is also in charge of organizing the social activities and educational meetings (such as the EC) to which the beneficiaries are supposed to participate. As a consequence, the ML's often assume a prominent and visible role in the community.

As the theory of social capital suggests, the interaction requirement might create an environment where social networks operate to improve their wellbeing. Our CCT would affect social capital once the program is able to affect social interactions and their environment (James S. Coleman 1988). FA may create networks or strengthen the current ones and improve the structure of social relationships among beneficiaries (Putnam 1995), promote leadership (Latham and Saari 1979; Bass 1991) and give mothers

\footnotetext{
${ }^{29}$ For evidence of success of FA on the target outcomes and other outcomes such as crime and voting behavior see a survey in Attanasio et al. (2015).

${ }^{30} \mathrm{In}$ addition to the EC, the beneficiaries take part in the general assembly. The general assembly is a public meeting where beneficiaries discuss and decide about problems affecting beneficiaries in Cartagena. The ML are elected in the general assembly. There are four annual assemblies, taking place on a date set by the local office.

${ }^{31}$ In Colombia, most welfare programs are targeted using the so-called SISBEN score, a poverty indicator that is updated periodically. On the basis of this score, households are assigned to one of six categories. FA targets the level 1 of SISBEN and displaced people.
} 
the opportunity to start working as a "social group" by perceiving a strong identification with the program (Tajfel 1982) and their power to act 'together' (Warren 1998). This not only facilitates group decisionmaking but also increases the willingness to intervene for the common good, which eventually could lead to overcoming collective action problems by enforcing pro-social norms.

In addition, our CCT may affect the beliefs about others' behavior. First, by becoming a beneficiary a new group identity emerges which would change the perception of the community traits. Beneficiaries share the same paperwork load, health check-ups, payment logistics and the same interests. Second, the EC and beneficiaries' assemblies are a place of encounter with people that face the same needs and interests. This continued interaction among beneficiaries could create and enforce social norms so beneficiaries' perception of trust or cooperation is also modified.

\section{Measuring Willingness to Cooperate: a Public Goods game}

The Public Goods game is a Voluntary Contribution Mechanism (VCM). Other studies employ a dichotomous VCM game comparable to the one we use here: Attanasio et al. (2012) in 70 rural municipalities in Colombia, Cárdenas et al. (2013) in 6 Latin American cities, Barr et al. (2012) in Uganda, Barr et al. (2014) in Albania and Alzua et al. (2014) in Mali ${ }^{32}$. The game captures the willingness to cooperate among the members of a group of 25 people by choosing simultaneously whether to allocate a token in the private account with a private benefit or to allocate the token in the group account, where the benefits of all members increases and the wellbeing of the entire group is improved ${ }^{33}$. There is no incentive to invest in the group account due to a higher individual payoff by investing in the private account. The dominant strategy is not to contribute at all, undermining the socially optimal outcome. However, if all in the group invest their token in the private account, the group will be worse-off than if all the members invested in the group account, which is the social optimum. The situation constitutes a typical social dilemma.

The possibility of cooperation within a group is determined by multiple factors such as repetition, communication, punishments or rewards and inequality in the payments ${ }^{34}$. In our game, the incentives to invest in the group account are given by the specific features of the design, but also by the individual motivations concerning the group wellbeing (Attanasio et al. 2009; Attanasio et al. 2015): Otherregarding preferences such as altruism, trust, social distance from the other members, fairness, reciprocity, a sense of affiliation as a member of a common group, or sympathy toward others in the group determine social cohesion in a group and strengthen the ability of its members to cooperate and

\footnotetext{
${ }^{32}$ For more details on the experimental design see Section 2 in the appendix and on the role of willingness to cooperate on the measurement of social capital see Attanasio et al. (2009, 2015).

${ }^{33}$ The dichotomous VCM makes the game easily understood by subjects and also time effective.

${ }^{34}$ See Attanasio et al. (2015) for a recent review.
} 
overcome collective action problems. In addition, community attributes such as social norms and institutions, informal enforcement mechanisms, concerns for social reputation, social reciprocity and group identification enforce the group interests over the individual, leading to attain a higher level of contribution and overcome the dilemma.

In the first round, each player has to decide where to invest her token. The second round is a repetition of the first, except that the players are allowed to discuss for ten minutes before making simultaneously their private, anonymous decision ${ }^{35}$. We use behavior in the second round as a measure of how effective the opportunity to communicate could be in increasing willingness to cooperate and solving a social dilemma in the community.

\section{Data}

We analyze individual behavior by means of our coordination and cooperation games, making extensive use of the survey data we collected at the end of the experiment. In what follows we describe the recruitment process, experimental procedures and descriptive statistics of our sample.

\section{i. $\quad$ Sampling, recruitment and allocation into sessions}

We recruited the participants to the game with the help of the local office of FA (Enlace Municipal) in two neighborhoods -Pozón and Ciénaga- in the city of Cartagena, Colombia ${ }^{36}$. The program was already operating in both neighborhoods and we were able to contact beneficiaries directly. Invitations were sent to 500 randomly selected participants from the FA beneficiaries list in each neighborhood. The FA office sent the invitations through the ML to those specific households in order to attend to any of the sessions held (a span of four days). We assumed a response rate of $70 \%$ and expected to run 14 sessions with 350 attendees in each neighborhood. The actual attendance rates for the new participants were $105.1 \%$ and 98.9\% in Ciénaga and Pozón respectively. Our sample consisted of 714 participants, 710 of which had not participated in any game before. ${ }^{37}$ This led to a total of 29 sessions with people who had never played before any game (14 in Pozón and 15 in Ciénaga), the average size being 24.7 participants.

Conducting lab in the field experiments in large cities presents many challenges in terms of costs, time, recruitment and attendance (Candelo and Polania-Reyes 2008; Nopo et al. 2008). Since the sessions were scheduled on a short notice (less than a week) we gave the beneficiaries as much freedom to choose

\footnotetext{
${ }^{35}$ Communication is completely unstructured and during the discussion, the players can talk about whatever they want but they cannot leave the room. No one, except the experimenter, knows the other players' contributions in the first round.

${ }^{36}$ For more details on the CCT program a why we chose Cartagena, see Section 1 in the appendix.

${ }^{37}$ In 2007, we conducted only the VCM with 676 participants. In 2008, in addition to the sessions with new participants we also invited individuals who had participated in the public goods game in 2007. In 2008 we conducted a total of 53 sessions, 26 in Pozón and 27 in Ciénaga. 24 of these sessions had only former participants. The VCM protocol followed in the two years was identical. These old participants were meant to attend to sessions with only old participants. However, 4 people managed to stay in new sessions.
} 
the session that suited them best as we could. This could have led to relatives or neighbors choosing the same sessions, if they both happened to be invited. In fact, some invited beneficiaries arrived to the session in groups ${ }^{38}$. In both neighborhoods participants self-selected into sessions by responding to an invitation, hence the study is not based on a random sample but on a self-selected sample. The fact that individuals are not randomly allocated into sessions allowed us to explore the role of social networks on the effect of exposure to the program and social capital: We were able to obtain enough variation in terms of the density and quality of the network across sessions (See Table 6).

There is the possibility of contamination among subjects of different sessions: participants to a session could talk to participants to the next session on the way out, although we put lot of effort in avoiding these contacts. Session level controls for this potential issue include the average outcome in the two sessions immediately before and an indicator variable for those sessions which were the first ones of the day.

\section{ii. Experimental procedures}

Participants were invited to come to the local public school in their neighborhood. After collecting their identification documents and checking their names on the recruitment lists, subjects in each session were given a random identification number and seated in semi-circle in a classroom where the instructions of the games were read and explained. After the participants played the second round of the game described above, we collected a network questionnaire on the existing relationships among them while they had a snack.

Having collected the individual network data and assigned every participant to a group according to the score we generated (see Section III above), we proceeded with the coordination game. The instructions of the coordination game were read and explained. After making sure the participants understood the game, subjects were seated in three circles, back facing, in a different classroom. They proceeded with their decision, simultaneously and without communication. The results were announced to each group in private. Afterwards we announced the results of the PG game, the subjects took a survey that gathered information on a wide range of socio-economic features.

A session lasted on average two hours. Once the session ended participants were paid their earnings ${ }^{39}$ based on the decisions in the experiments. On average each participant earned US\$10.04

\footnotetext{
${ }^{38}$ For example, implementing sessions with 25 randomly allocated individuals was impractical and infeasible. The two neighborhoods are a 2 hour-drive apart; in order to minimize 'cross-talk' and its effects - participants talking about the experiment to future players who will participate in subsequent sessions, sessions were implemented in a four-day frame with four sessions each day in each neighborhood. For example, during the first four days we conducted the experiments with participants in Pozón and the following four days with participants in Ciénaga.

${ }^{39}$ Those who chose not to participate were paid on their way out. All recruited people were given a show-up fee of US\$1.1, to induce credibility and subsidize their transportation from and to their home or workplace.
} 
(COL\$17595), which just over the value of the daily minimum wage ${ }^{40}$.

\section{iii. $\quad$ Characteristics of short and long exposure beneficiaries of the CCT}

In this section we include evidence to reassure on the comparability of samples in each neighborhood, by testing for the presence of the difference in observable variables that could indicate different selection process. This is the logic used -in a different context- by Joseph G Altonji et al. (2005); Joseph G. Altonji et al. (2008); Joseph G Altonji et al. (2013): if one does not find significant differences in terms of observables it is plausible to assume that there are no unobserved selection biases. Table 2 reports results separately for participants corresponding to the two levels of program exposure as of 2008: short exposure means less than a year in the program, whereas long exposure means over one year in the program $)^{41}$. Participants come from very poor families, with low levels of income and education. In Table 2 we also report the means by the main characteristics of the sample of a set of individual and household level characteristics, in Panel a, those variables we consider variables that are exogenous to the program, household socio-economic characteristics. In Panel b, we report what we consider endogenous variables such as perception of wealth and CCT related variables. Both long and short exposure groups are very similar in important dimensions such as education level, asset tenure and income, although some small (though relevant) differences emerge. As Panel b shows, all households that belong to the Long exposure sample live in the Pozon neighborhood and $90 \%$ of the short exposure sample live in the Cienaga neighborhood. As Attanasio et al. (2009); Attanasio et al. (2015) document, Pozon has more access to public services and better dwelling conditions than Cienaga. We have the same concern in our sample. However, Attanasio et al. (2015) have a bigger sample and able to show that selection bias is a possibility but is harmless ${ }^{42}$.

Long exposure households have better dwelling conditions and more access to public services than Short exposure households. In addition, Participants with long exposure were more likely to have a partner, own the house where they lived, to own durables and to receive governmental aid by other social programs. The perception that the household income is above others' income in the neighborhood is

\footnotetext{
40 The daily minimum wage was COL\$15383 for 2008. Source: www.banrep.gov.co

${ }^{41}$ The samples coincide almost exactly with the limits of Pozón (long exposure) and Ciénaga (short exposure) apart from 41 observations from Pozón that were subject to short exposure. This is due to new households in Pozón who became beneficiaries in the 2007 urban expansion (see more information in section i.in the appendix).

${ }^{42}$ While it is true that the neighborhoods were different in some observables characteristics in 2007 , we observe that these differences are stable over time (see Table 2 in Attanasio et al. (2015) that compares characteristics in Pozón 2007 and 2008 and Ciénaga 20072008 and Table B1 and B2 in their appendix the time trend of structural characteristics within neighborhoods for Independent cross section and Panel data (i.e. same individuals in Pozón 20072008 and same individuals in Ciénaga 2007 2008). In addition, some key characteristics not affected by the program do not change. Basic individual and household characteristics that are unlikely to be affected by FA are found to be overall stable across 2007 and 2008 within Cienaga and Pozon.
} 
higher for those with long exposure to the program. For instance owning a house and a mobile phone and monthly income may be affected by the fact that participants with long exposure had received the benefits from FA and other programs for a longer time. While there might be a causal effect of the program, we also found counterintuitive results such as lower likelihood of access to electricity and a landline.

Table 2 a. Socio-economic characteristics of the participants by time of exposure to the CCT

\begin{tabular}{|c|c|c|c|c|c|}
\hline & Exogenous Variable & All & $\begin{array}{c}\text { Long } \\
\text { Exposure }\end{array}$ & $\begin{array}{c}\text { Short } \\
\text { Exposure }\end{array}$ & Difference \\
\hline \multirow{7}{*}{$\begin{array}{c}\text { General } \\
\text { characteristics }\end{array}$} & Percentage of female participants & 98 & 99 & 98 & 1 \\
\hline & Average age (years) & 36.2 & 36.8 & 35.8 & 1.1 \\
\hline & Years living in the neighborhood & 18.5 & 14.9 & 21.2 & $-6.3 * * *$ \\
\hline & Percentage displaced & 13 & 17 & 10 & $7 * *$ \\
\hline & Percentage household head & 33 & 24 & 40 & $-16 * * *$ \\
\hline & Percentage Single & 11 & 10 & 12 & -1 \\
\hline & Percentage married of civil partnership & 72 & 78 & 68 & $10 * *$ \\
\hline \multirow{6}{*}{$\begin{array}{c}\text { Educational level } \\
\text { (percentage) }\end{array}$} & None (level 0) & 3 & 2 & 3 & -0 \\
\hline & Primary incomplete (level 1) & 21 & 22 & 20 & 2 \\
\hline & Primary complete (level 2) & 14 & 16 & 13 & 3 \\
\hline & Secondary incomplete (level 3) & 33 & 35 & 31 & 4 \\
\hline & Secondary complete (level 4) & 20 & 16 & 23 & $-6^{*}$ \\
\hline & More than secondary complete (level 5 & 9 & 8 & 10 & -2 \\
\hline \multirow{5}{*}{$\begin{array}{c}\text { Income } \\
\text { variables }\end{array}$} & Percentage unemployed & 4 & 3 & 5 & -2 \\
\hline & Percentage with access to credit & 71 & 72 & 70 & 2 \\
\hline & Percentage with access to formal credit & 22 & 24 & 22 & 2 \\
\hline & Per. with food insecurity level (high) & 9 & 7 & 10 & -2 \\
\hline & Per capita monthly income (US\$) & 32.0 & 33.3 & 31.0 & 2.3 \\
\hline \multirow{4}{*}{$\begin{array}{c}\text { Dwelling } \\
\text { characteristics }\end{array}$} & Household size & 5.67 & 5.59 & 5.72 & -0.13 \\
\hline & Number of people per room & 2.98 & 3.21 & 2.81 & $0.40 * * *$ \\
\hline & Percentage dwelling with dirt floor & 28 & 32 & 25 & $6 *$ \\
\hline & Percentage owning own house & 59 & 69 & 52 & $17 * * *$ \\
\hline \multirow{4}{*}{$\begin{array}{l}\text { Public services } \\
\text { (percentage) }\end{array}$} & Water by pipe & 88 & 92 & 84 & $8 * *$ \\
\hline & Sewer system & 46 & 68 & 30 & $38 * * *$ \\
\hline & Does not have electricity & 3 & 6 & 2 & $4 * *$ \\
\hline & Land phone & 18 & 8 & 24 & $-16 * * *$ \\
\hline \multirow{3}{*}{$\begin{array}{c}\text { Assets } \\
\text { (percentage) }\end{array}$} & Mobile phone & 72 & 78 & 68 & $9 * *$ \\
\hline & DVD player & 33 & 37 & 31 & 6 \\
\hline & Sound player & 31 & 37 & 27 & $10 * * *$ \\
\hline \multicolumn{2}{|l|}{ Observations } & 714 & 346 & 368 & 714 \\
\hline
\end{tabular}

Robust standard errors, clustered by session. * Significant at $10 \% ; * *$ significant at 5\%; *** significant at $1 \%$. According to the official exchange rate at that date TRM: US\$1=COL\$1753.01 (monthly mean average for July 2008, http://www.oanda.com)

Participants who have been enrolled in the program for less than a year are significantly more likely to be head of household, have been living in the neighborhood for more years and have more years of education. In this case there might be a reverse causation: latter expansions of the CCT program might be explicitly targeting sectors that were previously not in. Whilst some of the effect of FA may be through its impact on socio economic outcomes, the relatively small size of differences and the presence of counterintuitive associations do not give strong support to conclude that all of its impact is through that channel. 
Table 2 b. Characteristics of the participants by time of exposure to the CCT

\begin{tabular}{|c|c|c|c|c|c|}
\hline & Endogenous Variable & All & $\begin{array}{c}\text { Long } \\
\text { Exposure }\end{array}$ & $\begin{array}{c}\text { Short } \\
\text { Exposure }\end{array}$ & Difference \\
\hline \multirow{4}{*}{$\begin{array}{l}\text { Perception that } \\
\text { HH income }\end{array}$} & ...is above the lowest possible & 70 & 72 & 69 & 2 \\
\hline & ...is above the highest possible & 43 & 47 & 40 & $7 * * *$ \\
\hline & ...is above the average & 56 & 59 & 54 & $5 * *$ \\
\hline & is in which percentile & 33 & 35 & 31 & $4 * *$ \\
\hline \multirow{3}{*}{ CCT measures } & Lives in Pozon & 48 & 100 & 10 & $90 * * *$ \\
\hline & Years since enrollment & 2.06 & 3.42 & 1.05 & $2.37 * * *$ \\
\hline & Years since first payment & 1.87 & 3.20 & 0.88 & $2.32 * * *$ \\
\hline \multirow{6}{*}{$\begin{array}{l}\text { The participant } \\
\text { has received } \\
\text { (different from } \\
\text { FA) }\end{array}$} & Any other governmental aid & 28 & 39 & 19 & $20 * * *$ \\
\hline & Gov. aid for her house & 14 & 27 & 4 & $22 * * *$ \\
\hline & Gov. aid for productive tasks & 3 & 4 & 1 & $3 * *$ \\
\hline & Gov. aid for childcare & 8 & 7 & 10 & -3 \\
\hline & Gov. aid for health and nutrition & 17 & 32 & 6 & $26 * * *$ \\
\hline & Gov. aid for education & 15 & 28 & 5 & $22 * * *$ \\
\hline \multicolumn{2}{|l|}{ Observations } & 714 & 346 & 368 & 714 \\
\hline
\end{tabular}

Robust standard errors, clustered by session. * Significant at $10 \% ; * *$ significant at 5\%; *** significant at $1 \%$.

In Table 3, we report the measures collected from the Minimum Effort game. We present the results separately by length of exposure (short or long) to the program. In all relevant variables that indicate the ability to coordinate on the efficient outcome, players with long exposure show significantly higher measures with $+28 \%$ participants choosing the highest level of effort and $+25 \%$ groups actually achieving the Pareto-efficient equilibrium. The percentage of individuals choosing the safe option was $26 \%$ higher among those with short exposure. While $+26 \%$ short exposure participants chose the lowest level of effort and $+35 \%$ short exposure groups achieved the risk-dominant equilibrium. This is consistent with the hypothesis that the longer the exposure to the program the better a community will coordinate.

In Table 4 we report behavior in the Public Goods game and experimental characteristics at the session level. We also report differences across levels of exposure in these cooperation measures. First, though the unique Nash equilibrium of the game is for individuals to invest their token in the private account, many individuals deviate from the Nash equilibrium and contribute to the public good. Despite having a very low MPC and conducting the game in an urban context, the overall level of cooperation we observe in our sample is similar to that observed in similar labs in the field. However, the level of cooperation in the first round among the short exposure sample is significantly higher than in the long exposure one. In the second round, there is no significant difference in the cooperation variables. Finally, we observe that in the short exposure sample, the percentage of participants who had a perfect understanding of the Public Goods game was significantly higher. We would expect that cooperation should be higher in the Long exposure group than in the short exposure one. Attanasio et al. (2015) examine these intriguing effects by using a difference in difference regression analysis with data from 2007 and 2008, which controls for possible unobservable variables. They find that there was indeed a positive effect of the program in cooperation in the first round 
Table 3. Behavior in the Coordination game

\begin{tabular}{|c|c|c|c|c|}
\hline Variable & All & $\begin{array}{c}\text { Long } \\
\text { Exposure }\end{array}$ & $\begin{array}{c}\text { Short } \\
\text { Exposure }\end{array}$ & Difference \\
\hline Average effort decision ${ }^{b}$ & $\begin{array}{c}2.34 \\
(0.11)\end{array}$ & $\begin{array}{c}2.65 \\
(0.12)\end{array}$ & $\begin{array}{c}2.11 \\
(0.13)\end{array}$ & $\begin{array}{c}0.54 * * * \\
(0.17)\end{array}$ \\
\hline Percent of players that chose 1 & $\begin{array}{c}24 \\
(0.5)\end{array}$ & $\begin{array}{l}10 \\
(0.4)\end{array}$ & $\begin{array}{l}35 \\
(0.7)\end{array}$ & $\begin{array}{c}-26^{* * * *} \\
(0.8)\end{array}$ \\
\hline Percent of players that chose 3 & $\begin{array}{l}59 \\
(0.6)\end{array}$ & $\begin{array}{l}75 \\
(0.8)\end{array}$ & $\begin{array}{c}46 \\
(0.6)\end{array}$ & $\begin{array}{c}28 * * * \\
(1.0)\end{array}$ \\
\hline Average Minimum effort in the group ${ }^{b}$ & $\begin{array}{c}1.54 \\
(0.13)\end{array}$ & $\begin{array}{c}1.88 \\
(0.21)\end{array}$ & $\begin{array}{l}1.28 \\
(0.10)\end{array}$ & $\begin{array}{c}0.61 * * * \\
(0.21)\end{array}$ \\
\hline Percent of groups with a ME of 1 & $\begin{array}{c}64 \\
(0.7)\end{array}$ & $\begin{array}{c}43 \\
(1.0)\end{array}$ & $\begin{array}{c}79 \\
(0.7)\end{array}$ & $\begin{array}{c}-35 * * * \\
(1.2)\end{array}$ \\
\hline Percent of groups with a ME of 3 & $\begin{array}{l}17 \\
(0.6)\end{array}$ & $\begin{array}{c}31 \\
(1.2)\end{array}$ & $\begin{array}{c}6 \\
(0.3)\end{array}$ & $\begin{array}{l}25^{* *} \\
(1.1)\end{array}$ \\
\hline Size of the group $B^{a}$ & $\begin{array}{c}8.70 \\
(0.12)\end{array}$ & $\begin{array}{c}8.79 \\
(0.13)\end{array}$ & $\begin{array}{c}8.62 \\
(0.19)\end{array}$ & $\begin{array}{c}0.17 \\
(0.22)\end{array}$ \\
\hline $\begin{array}{l}1 \text { if the player understood that the best outcome is everyone } \\
\text { to choose level of effort } 3\end{array}$ & $\begin{array}{c}0.66 \\
(0.02)\end{array}$ & $\begin{array}{c}0.70 \\
(0.03)\end{array}$ & $\begin{array}{c}0.63 \\
(0.02)\end{array}$ & $\begin{array}{c}0.08 * * \\
(0.03)\end{array}$ \\
\hline Number of groups & 87 & 42 & 45 & 87 \\
\hline
\end{tabular}

Robust Standard errors, clustered at the session level, in parenthesis. * Significant at 10\%; **significant at 5\%; *** significant at $1 \% .{ }^{a}$ In all sessions groups $\mathrm{A}$ and $\mathrm{C}$ had 8 players each. ${ }^{\mathrm{b}}$ The average of $1,2,3$ units of effort.

Table 4. Behavior in the Public Goods game

\begin{tabular}{|c|c|c|c|c|c|}
\hline Level & Variable & All & $\begin{array}{l}\text { Long } \\
\text { Exposure }\end{array}$ & $\begin{array}{l}\text { Short } \\
\text { Exposure }\end{array}$ & Difference \\
\hline \multirow{8}{*}{ Round 1} & \multirow[t]{2}{*}{ Average percentage of contributors } & 29 & 22 & 34 & $-12 *$ \\
\hline & & $(0.4)$ & $(0.4)$ & $(0.5)$ & $(0.7)$ \\
\hline & \multirow[t]{2}{*}{ Percentage of sessions with no contribution } & 11 & 15 & 7 & 7 \\
\hline & & $(0.6)$ & (1.0) & $(0.6)$ & (1.1) \\
\hline & \multirow[t]{2}{*}{ Median percentage of contributors } & 10 & 0.0 & 17 & $-17 *$ \\
\hline & & $(0.5)$ & $(0.0)$ & $(0.9)$ & $(0.9)$ \\
\hline & \multirow[t]{2}{*}{ Maximum percentage of contributors } & 89 & 85 & 93 & -7 \\
\hline & & $(0.6)$ & $(1.0)$ & $(0.6)$ & $(1.1)$ \\
\hline \multirow{8}{*}{ Round 2} & \multirow[t]{2}{*}{ Average percentage of contributors } & 27 & 26 & 29 & -3 \\
\hline & & $(0.4)$ & $(0.7)$ & $(0.5)$ & $(0.8)$ \\
\hline & \multirow[t]{2}{*}{ Percentage of sessions with no contribution } & 14 & 23 & 7 & 16 \\
\hline & & $(0.7)$ & (1.2) & $(0.6)$ & (1.3) \\
\hline & \multirow{2}{*}{ Median percentage of contributors } & 17 & 23 & 13 & 10 \\
\hline & & $(0.7)$ & (1.2) & $(0.8)$ & (1.4) \\
\hline & \multirow[t]{2}{*}{ Maximum percentage of contributors } & 86 & 77 & 93 & -16 \\
\hline & & $(0.7)$ & $(1.2)$ & $(0.6)$ & (1.3) \\
\hline \multirow{6}{*}{$\begin{array}{l}\text { Session } \\
\text { Level }\end{array}$} & \multirow{2}{*}{ Session size } & 24.65 & 24.74 & 24.58 & 0.16 \\
\hline & & $(0.14)$ & $(0.16)$ & $(0.21)$ & $(0.26)$ \\
\hline & \multirow{4}{*}{$\begin{array}{l}1 \text { if the player understood that the best outcome is } \\
\text { everyone investing in the group account } \\
1 \text { if the player declares she understood everything }\end{array}$} & 0.20 & 0.13 & 0.25 & $-0.12 * * *$ \\
\hline & & $(0.02)$ & $(0.03)$ & $(0.02)$ & $(0.04)$ \\
\hline & & 0.67 & 0.67 & 0.68 & -0.01 \\
\hline & & $(0.02)$ & $(0.04)$ & $(0.03)$ & $(0.05)$ \\
\hline \multicolumn{2}{|c|}{ Number of sessions } & 29 & 14 & 15 & 29 \\
\hline
\end{tabular}

Robust Standard errors that are clustered at the session level in parenthesis. The standard errors for the median and maximum statistics are calculated at session level. * Significant at 10\%; ** significant at 5\%; *** significant at $1 \%$.

In Table 5, we report the descriptive statistics on several measures of social capital collected from the post-game survey and also report some characteristics related with the social component of the CCT. 
These measures are divided into four groups: variables based on individual participation to civic associations and neighborhood activities; variables reflecting voting behavior ${ }^{43}$, variables derived from answers to questions about trust and perception of cooperativeness ${ }^{44}$ and variables on attendance to the CCT meetings and the presence of the ML in the session.

In the first group, we report the percentage of participants actively involved in neighborhood decisions or meetings on topics related to the community, and for active members in (at least one) civic organization, the percentage of participants who attend the meetings, perceive themselves as a leader or decision maker in that association, support the association with money or voluntary work and the number of hours per month spent in that association. Compared to what was observed in other studies in Colombia (Latorre López 2004; Polania-Reyes 2005) the participants reported higher levels of participation in organized groups. Participants with long exposure are $+15 \%$ involved in associations than participants with short exposure.

In the second group we report the percentage of individuals who voted in local and presidential elections, showing a $15 \%$ higher turnout among those with long exposure, which is consistent with studies on voting behavior and CCT (see Nupia (2011); Zárate et al. (2013) for evidence on other countries see Attanasio et al. (2015)).

In the third group, we report statistics derived from a question on trust ${ }^{45}$. Individuals may also have different perceptions on others' social preferences. They may perceive either a reciprocal ("most people help if others help"), selfish ("most people care only about themselves"), or cooperative ("most people help others unconditionally") behavior in their neighbors' actions. The levels of trust and perception about social preferences are no different across levels of exposure.

Finally, we report that the percentage of players that attended at least one meeting of care (EC) and the number of meetings the participant has attended to, are significantly higher in the long exposure group. Only 5 percent of the participants are self-reported as ML and at least a ML was present in $79 \%$ of the sessions.

\footnotetext{
${ }^{43}$ The last local elections in Cartagena (Governor, mayor, members of the Asambleas Departamentales, Municipal council and Juntas Administradoras Locales) were held three months after the inscription in the program (Oct. 2007) and eight months before the beginning of the program in Pozón (April 2003). Presidential elections were held sixteen months after the beginning of the program in Pozón, in May 2006.

${ }^{44}$ There is a risk that the attitudinal measures of social capital were influenced by the experimental games (Carpenter 2002) as the players answered the questionnaire after they knew the outcome of the games and they possibly might have expressed their emotions in their answers on perception of trust and cooperation.

${ }^{45}$ This question was adapted from the WVS source. We added an alternative "few people can be trusted".
} 
Table 5. Traditional social capital and CCT social capital measures

\begin{tabular}{|c|c|c|c|c|c|c|}
\hline & \multicolumn{2}{|c|}{ Percentage (unless stated otherwise) } & All & Long Exposure & Short Exposure & Difference \\
\hline \multirow{11}{*}{ Civic Participation } & \multicolumn{2}{|c|}{ Participation in neighborhood decisions } & 41 & 43 & $39-1$ & 4 \\
\hline & \multicolumn{2}{|c|}{ Participation in the neighborhood meetings } & 48 & 51 & 45 & $6^{*}$ \\
\hline & \multicolumn{2}{|c|}{ Membership in at least one organization } & 27 & 35 & 20 & $15 * * *$ \\
\hline & \multicolumn{2}{|c|}{ Bonding Social capital } & 6 & 7 & 5 & 2 \\
\hline & \multicolumn{2}{|l|}{ Bridging Social capital } & 18 & 24 & 13 & $11 * *$ \\
\hline & \multicolumn{2}{|l|}{ Linking Social capital } & 11 & 16 & 8 & $8 * *$ \\
\hline & \multirow{5}{*}{$\begin{array}{l}\text { If is member of any } \\
\text { civic association }\end{array}$} & Attendance to the meetings & 26 & 34 & 20 & $14 * *$ \\
\hline & & Decision maker & 24 & 30 & 18 & $12 * *$ \\
\hline & & Leader & 10 & 12 & 8 & 4 \\
\hline & & Supports with money or work & 23 & 30 & 18 & $13 * * *$ \\
\hline & & No. Hours & 13.7 & 14.9 & 12.1 & 2.8 \\
\hline \multirow{2}{*}{ Voting behavior } & \multirow{2}{*}{\multicolumn{2}{|c|}{$\begin{array}{l}\text { Voted in local elections (2007) } \\
\text { Voted in presidential elections (2006) }\end{array}$}} & 72 & 73 & 72 & 1 \\
\hline & & & 78 & 88 & 70 & $17 * * *$ \\
\hline \multirow{6}{*}{$\begin{array}{c}\text { Trust and cooperation } \\
\text { perception }\end{array}$} & \multirow{3}{*}{ Trust } & Most people & 7 & 8 & 5 & 3 \\
\hline & & Few people & 62 & 60 & 63 & -3 \\
\hline & & None & 31 & 32 & 31 & 0 \\
\hline & \multirow{3}{*}{$\begin{array}{l}\text { Perception within the } \\
\text { community }\end{array}$} & Cooperation & 32 & 31 & 33 & -2 \\
\hline & & Reciprocity & 14 & 16 & 13 & 3 \\
\hline & & Self-regarding & 54 & 53 & 54 & -1 \\
\hline \multirow{5}{*}{$\begin{array}{l}\text { Always or usually, the } \\
\text { player has helped... }\end{array}$} & \multirow{5}{*}{\multicolumn{2}{|c|}{$\begin{array}{l}\text { anyone with money, food or clothes } \\
\text { by offering her seat in the bus } \\
\text { someone with domestic work } \\
\text { someone by carrying a case, package, groceries } \\
\text { someone by taking care of the house or children }\end{array}$}} & 9 & 11 & 8 & 4 \\
\hline & & & 24 & 25 & 24 & 0 \\
\hline & & & 12 & 15 & 10 & $5 *$ \\
\hline & & & 8 & 10 & 6 & $4 * *$ \\
\hline & & & 23 & 23 & 22 & 1 \\
\hline \multirow{4}{*}{ CCT measures } & \multicolumn{2}{|l|}{$\%$ ML in the session } & 5 & 6 & 5 & 0 \\
\hline & \multicolumn{2}{|c|}{ Players attended at least one meeting of care -EC } & 80 & 94 & 70 & $24 * * *$ \\
\hline & \multicolumn{2}{|c|}{ Number of meetings of care EC } & 2.3 & 4.0 & 1.1 & $2.9 * * *$ \\
\hline & \multicolumn{2}{|c|}{$\%$ At least one ML in the session } & 79 & 79 & 79 & 0 \\
\hline bservations & & & 714 & 346 & 368 & 714 \\
\hline
\end{tabular}

Robust standard errors of the difference, clustered by session. * Significant at 10\%;** significant at $5 \%$; *** significant at $1 \%$. Bonding social capital is defined as membership in charity and /or religious associations. Bridging social capital is defined as membership in Volunteer work, ethnic, cultural, sports, and environmental associations. Linking social capital is defined as membership in Community action, education (parents' network), security associations, unions or political parties. 
In Table 6 we present the average number of friends, acquaintances and connections (the sum of relatives, friends and acquaintances) each participant reports in the session and within coordination group (i.e. A, participants with the highest connectivity score in the session and $\mathrm{C}$, participants with the lowest score $)^{46}$. We also report features of the in-session network such as the friendship, acquaintanceship and connectivity densities (measured as the ratio of the total number of identified specific links in the session and the total possible number of specific links among connected people, i.e. those individuals that are identified as an acquaintance at least once by another player). In addition, we present a measure of leadership given by the percentage of players identified as an informal leader in each session (i.e. a person different to the ML), at least by one different player in the session. The fact that there are no statistical differences in terms of connectivity between levels of exposure indicates the recruitment process was successful.

Table 6. Network characteristics across sessions

\begin{tabular}{clcccc}
\hline & Variable & All & $\begin{array}{c}\text { Long } \\
\text { Exposure }\end{array}$ & $\begin{array}{c}\text { Short } \\
\text { Exposure }\end{array}$ & Difference \\
& Average degree of relatives a & 0.13 & 0.14 & 0.13 & 0.01 \\
& Average degree of friends & 1.46 & 1.46 & 1.46 & -0.00 \\
& Average degree of acquaintances & 0.44 & 0.50 & 0.40 & 0.10 \\
Session level & Average degree of trustworthy players & 1.50 & 1.48 & 1.52 & -0.05 \\
(714 obs.) & Friendship density b & 0.11 & 0.11 & 0.11 & -0.00 \\
& Acquaintanceship density & 0.03 & 0.04 & 0.03 & 0.01 \\
& Percentage of players identified as leader & 0.18 & 0.20 & 0.16 & 0.04 \\
& Score & 5.38 & 5.45 & 5.32 & 0.13 \\
\hline \multirow{3}{*}{ Group Level A A } & Average degree of relatives & 0.22 & 0.29 & 0.17 & 0.12 \\
(232 obs.) & Average degree of friends & 1.99 & 1.93 & 2.04 & -0.11 \\
& Average degree of acquaintances & 0.41 & 0.42 & 0.40 & 0.02 \\
& Average degree of trustworthy players & 2.08 & 2.05 & 2.10 & -0.05 \\
& Percentage of players identified as leader & 23.3 & 22.0 & 24.0 & -2.0 \\
\hline \multirow{3}{*}{ Group Level C C } & Average degree of relatives & 0.00 & 0.00 & 0.00 & 0.00 \\
(232 obs.) & Average degree of friends & 0.00 & 0.00 & 0.00 & 0.00 \\
& Average degree of acquaintances & 0.01 & 0.01 & 0.01 & 0.00 \\
& Percentage of players identified as leader & 15.9 & 18.0 & 0.00 & 0.00 \\
\hline
\end{tabular}

${ }^{a}$ Average degree for a network graph is the average number of edges that nodes in the network have. ${ }^{b}$ Network density is the average degree divided by $(\mathrm{N}-1)$, where $\mathrm{N}$ is the number of nodes in the network. Robust standard errors of the difference clustered by session. For more details on the Network analysis see Advani and Malde (2014). * Significant at 10\%; ** significant at 5\%; *** significant at $1 \%$.

\footnotetext{
${ }^{46}$ Table 6 also provides validity to the effectiveness of the score in allocating the most connected individuals into group $\mathrm{A}$ and the least connected in group $\mathrm{C}$. We also find that the percentage of players identified as leaders is significantly lower in group C (15.9) than in group A (23.3, with a p-value of 0.00). Interestingly, the rate of reported leaders is significantly higher than the proportion of ML (participants who declared to have been elected FA beneficiary representatives) $(5.2 \%$ and $5.1 \%$ respectively). We find that $46.2 \%$ among those identified as leaders in the session are MLs.
} 


\section{Relation between the CCT and behavior in the coordination game g $^{47}$}

First, we look at the differences between the frequencies of choosing the risk-dominant and the Paretodominant outcomes in terms of exposure to the program. Figure 1 presents this comparison and also compares the differences among connectivity groups A, B and C. We observe that there is no difference across groups. However, there is a significant difference in exposure, regardless of which group the individuals were allocated to.

\section{Figure 1. Exposure to the program and individual effort decision by players' degree allocation group}

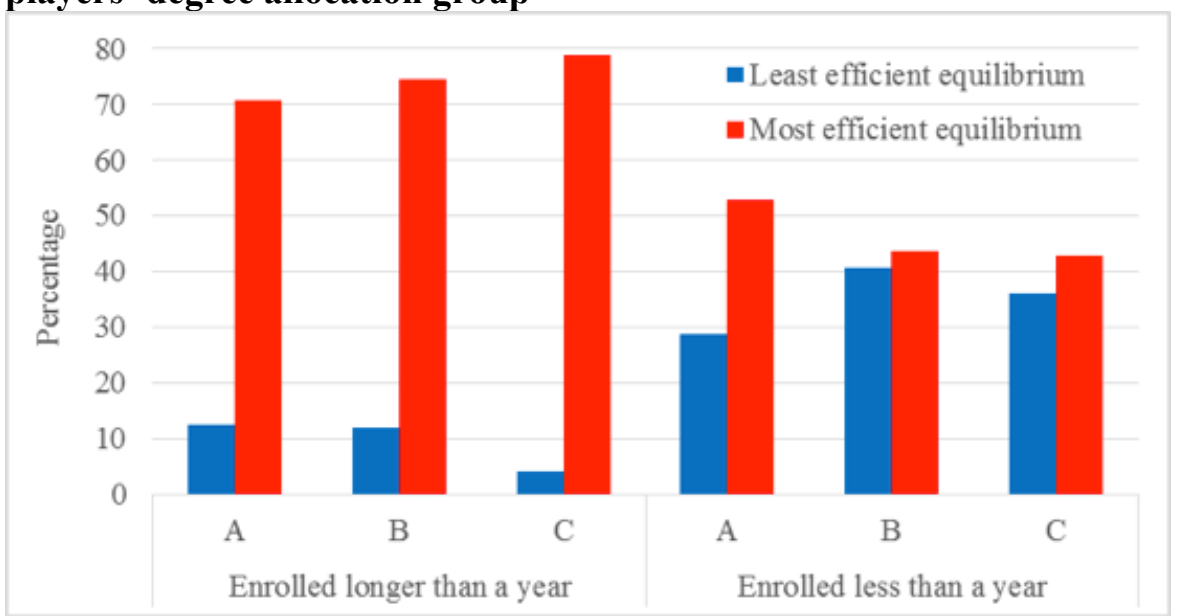

Note: A player's degree is the number of edges or relationships the player declares to have within the session. Every player has a weighed measure of her degree of friends, degree of relatives and degree of trustworthy acquaintances. Those with the highest measure are allocated to group A, those with the lowest measure to group $\mathrm{C}$ and the remaining ones to group $\mathrm{B}$. We observe that regardless of the group, players with a higher exposure to the program coordinate into the Pareto optimal equilibrium whereas players with a lower exposure coordinate more in the risk-dominant equilibrium.

\section{i. $\quad$ Coordination game and other measures of social capital: reduced-form}

Second, we look at the relation between the effort decision and survey social capital measures. In Table 7 we report the relation between dichotomous and continuous social capital measures and the decision of effort in the coordination game, where - 1 is the lowest level of effort and 1 is the highest level of effort. In the upper panel, we report the marginal effect of the effort decision in a probit regression model for each dummy social capital variable. In the lower panel, we report the effect of the effort decision in a linear regression model for each continuous social capital variable. We find no relation between the level of effort in the coordination game and social capital measures.

\footnotetext{
${ }^{47}$ In section 3 of the appendix we report the relation between traditional social capital measures collected in the survey introduced in Table 6.4 and exposure to the CCT. As controls we included willingness to cooperate, the ability to coordinate as well as network information and individual socio-economic characteristics. Among the socio-economic characteristics we include especially those characteristics we found to show differences between the short exposure and long exposure samples.
} 
Table 7. Relation between the effort decision and survey social capital measures

\begin{tabular}{|c|c|c|c|c|c|}
\hline \multirow{2}{*}{\multicolumn{2}{|c|}{$\begin{array}{l}\text { Independent variable: } \\
\text { Dependent variable: Dummy survey measures }\end{array}$}} & \multicolumn{4}{|c|}{ Effort decision $(-1,0,1)$} \\
\hline & & 1_E & 2_E & 4_E & 5_E \\
\hline \multicolumn{2}{|c|}{ Participation in neighborhood decisions } & 0.03 & 0.02 & 0.03 & 0.02 \\
\hline \multicolumn{2}{|c|}{ Participation in the neighborhood meetings } & 0.02 & 0.01 & 0.00 & 0.00 \\
\hline \multicolumn{2}{|c|}{ Membership in at least one organization } & 0.02 & -0.01 & -0.01 & -0.01 \\
\hline \multicolumn{2}{|c|}{ Bonding Social capital } & 0.01 & -0.01 & -0.01 & -0.01 \\
\hline \multicolumn{2}{|c|}{ Bridging Social capital } & 0.02 & 0.00 & 0.00 & -0.00 \\
\hline \multicolumn{2}{|c|}{ Linking Social capital } & 0.00 & -0.00 & -0.00 & -0.00 \\
\hline \multicolumn{2}{|c|}{ Membership in a charity } & 0.00 & -0.00 & -0.00 & -0.00 \\
\hline \multicolumn{2}{|c|}{ Membership in a religious association } & 0.00 & -0.01 & -0.01 & -0.01 \\
\hline \multicolumn{2}{|c|}{ Membership in a community action association } & -0.00 & -0.01 & -0.00 & -0.00 \\
\hline \multicolumn{2}{|c|}{ Voted in local elections (2007) } & -0.00 & -0.01 & -0.00 & -0.01 \\
\hline \multicolumn{2}{|c|}{ Voted in presidential elections (2006) } & 0.00 & $-0.03 *$ & $-0.04 * *$ & $-0.04 * *$ \\
\hline \multirow{3}{*}{$\begin{array}{l}\text { Trust: do you consider that you } \\
\text { can trust in? }\end{array}$} & consider that you & 0.01 & 0.01 & 0.01 & 0.00 \\
\hline & consider that you & 0.02 & 0.02 & 0.03 & 0.02 \\
\hline & rust in? & -0.03 & -0.03 & -0.04 & -0.03 \\
\hline \multirow{2}{*}{\multicolumn{2}{|c|}{ Perception within the community }} & -0.02 & -0.02 & -0.02 & -0.02 \\
\hline & & $0.02^{*}$ & 0.02 & 0.02 & 0.01 \\
\hline & Self-regarding & -0.00 & -0.00 & -0.00 & 0.00 \\
\hline \multirow{5}{*}{$\begin{array}{c}\text { Always or } \\
\text { usually, has she } \\
\text { helped }\end{array}$} & anyone with money, food or clothes & $0.02 *$ & 0.02 & 0.02 & 0.02 \\
\hline & by offering her seat in the bus & 0.01 & 0.01 & 0.01 & 0.01 \\
\hline & someone with domestic work & 0.02 & 0.01 & 0.01 & 0.01 \\
\hline & someone by carrying stuff & $0.03^{* *}$ & 0.03 & $0.03 * *$ & $0.03 * *$ \\
\hline & someone by childcare & 0.04 & 0.04 & 0.04 & 0.03 \\
\hline \multirow{4}{*}{$\begin{array}{l}\text { CCT program } \\
\text { measures }\end{array}$} & She is a ML & -0.00 & -0.00 & 0.00 & 0.00 \\
\hline & She has attended to EC meetings & 0.02 & -0.02 & -0.02 & -0.02 \\
\hline & If anyone consider the player a leader & 0.02 & 0.01 & 0.01 & 0.01 \\
\hline & There is at least a ML & 0.01 & 0.02 & 0.01 & 0.02 \\
\hline \multicolumn{2}{|c|}{ Dependent variable: Continuous survey measures } & $1 \_\mathrm{E}$ & $2 \_\mathrm{E}$ & 4_E & 5_E \\
\hline \multirow{2}{*}{$\begin{array}{l}\text { CCT program } \\
\text { measures }\end{array}$} & Number of meetings she has attended & $1.37 * * *$ & 0.02 & -0.10 & $2.10 * * *$ \\
\hline & $\%$ of ML in the session & $0.02 * *$ & 0.01 & 0.00 & $0.06 * * *$ \\
\hline \multirow{7}{*}{$\begin{array}{l}\text { Connectivity in } \\
\text { the group A. B, } \\
\text { C or session }\end{array}$} & Score & $2.87 * * *$ & $1.33^{*}$ & $0.82 *$ & $5.64 * * *$ \\
\hline & Number of connections & $1.07 * * *$ & $0.46^{*}$ & $0.26^{*}$ & $2.09 * * *$ \\
\hline & Degree of friends & $0.78 * * *$ & $0.37 *$ & $0.24 *$ & $1.56 * * *$ \\
\hline & Degree of relatives & $0.08 * * *$ & 0.04 & 0.02 & $0.14 * * *$ \\
\hline & Degree of acquaintances & $0.21 * * *$ & 0.05 & -0.00 & $0.39 * * *$ \\
\hline & $\%$ who considered the player as leader & $0.00 * *$ & 0.00 & -0.00 & $0.01 * * *$ \\
\hline & $\%$ informal leaders in the group/session & $0.09 * * *$ & 0.03 & 0.01 & $0.19 * * *$ \\
\hline \multirow{3}{*}{ Controls } & Beneficiary for longer than a year & No & Yes & Yes & Yes \\
\hline & Basic Characteristics & No & No & Yes & Yes \\
\hline & Network information & No & No & No & Yes \\
\hline
\end{tabular}

For dummy survey measures we report the marginal effects of probit regression. All specifications include cooperation decision in round 1 and 2 as controls. For the continuous survey measures we report the linear regression coefficients. Bonding social capital contains membership in charity and /or religious associations. Bridging social capital includes membership in Volunteer work, ethnic, cultural, sports, and environmental associations. Linking social capital contains membership in Community action, education (parents' network), security associations, unions or political parties. Robust Standard errors that are clustered at the session level in parenthesis. * Significant at 10\%;** significant at 5\%; *** significant at $1 \%$.

In the upper panel of Table 7, we observe that the effort decision is only related to voting in presidential elections (a negative and significant relation) and declaring that the player usually has helped 
someone from another household with the groceries or carrying packages ${ }^{48}$. In the lower panel we report that the effort decision is significantly related to all the network measures which suggest that network information may be an important confounding factor.

Third, we want to test the hypothesis that exposure is relevant for the ability to coordinate in the most efficient outcome. Our empirical specification has as its unit of observation individual $i$ of group $g$ in session $s$. We estimate the following partial proportional odds specification with three categories of the ordinal dependent variable, $Y_{i}$, the observed value of the unobserved individual effort decision, continuous latent variable $Y_{i}^{*}{ }^{49}$. The probability that $\mathrm{Y}$ will take on a particular value,

$$
P\left(Y_{i}>j\right)=g\left(X \beta_{j}\right)=\frac{\exp \left(\alpha_{j}+X_{1 i} \beta_{1}+X_{2 i} \beta_{2 j}\right)}{1+\left[\exp \left(\alpha_{j}+X_{1 i} \beta_{1}+X_{2 i} \beta_{2 j}\right)\right]} \text { for } j=1,2
$$

Where $X_{k i}$ are individual observable characteristics (a dummy for being enrolled in the program longer than a year) and $X_{1 i}$ are the variables that are constrained to be the same among levels of effort $e$ and $X_{2 i}$ are the variables that are set free to $\operatorname{differ}^{50}$. Standard errors are clustered by session.

We treat the decision of the level of effort as an ordinal outcome as we the three possible equilibria are ordered from the least (i.e. level of effort 1) to the most (i.e. level of effort 3) efficient equilibrium. In order to estimate the ordinal model, we applied Brant's test of parallel regression/ parallel lines/proportional odds assumption (see Long and Freese, 2006) which equivalent to a series of binary logistic regressions where categories of the dependent variable are combined, e.g. for $e=1$ category 1 is contrasted with categories 2 and 3; for $e=2$ the contrast is between categories 1 and 2 versus 3 . We confirmed the assumption of parallel regressions is not met (we have a significant overall chi-square

\footnotetext{
${ }^{48}$ For the relation between the decisions in the Public Goods game and social capital measures see Table A.4 a and b in the appendix. We find no relation on cooperation without communication whereas cooperative behavior after communication is related to helping others in the community, membership and participation in bonding and bridging associations. In Table A4c in the appendix we show the relation between the main network information (i.e. degree of friends, relatives and acquaintances the player identifies in the session) and dichotomous social capital measures. All of these are dummy survey measures and we report the marginal effect of the effort decision in a probit regression model for each social capital variable. Having friends and acquaintances reduces the probability to state that is not possible to trust in people in the community, which is a decrease in the perception of untrusting people in the community. These two network measures are also positively related with helping someone different from the household by taking care of the house or the children and with others declaring that the player is an informal leader in the session.

${ }^{49}$ The continuous latent variable $Y_{i}^{*}$ is equal to $Y_{i}^{*}=\alpha+\beta X_{i}+\lambda G_{g s}+\theta S_{s}+v_{s}+\varepsilon_{i}$, where the disturbance term $\varepsilon_{i}$ are i.i.d. Gaussian distributed error terms with mean zero and variance $\sigma_{\varepsilon}^{2}=1$, independent from $v_{s}$, which are iid, $N\left(0, \sigma_{v}^{2}\right)$.

${ }^{50} N_{\text {igs }}$ includes number of friends, relatives and acquaintances in the group, $S_{S}$ includes session size, a dummy if that was the first session of the day, and a dummy for one of the experimenters who conducted the session, $G_{g s}$ includes a dummy if there is a man in the group, the average equilibrium in the group from the previous two sessions and the presence of a ML in the group.
} 
value $^{51}$ : one or more coefficients differ across values of $j$. We also performed a likelihood-ratio test that confirms we cannot use an ordered logit model. However, it is not necessary either to implement a generalized ordered logistic model (Fu's, 1998) which sets all variables from the parallel-lines constraint since the assumption is violated only by one or a few of our independent variables, in particular the exposure to the program. We then fit a partial proportional odds model, where the parallel lines constraint is relaxed only for those variables where it is not justified ${ }^{52}$.

Table 8 presents our results with eight different specifications. In the first 4 specifications (I to IIIb) we relate the effort decision to other experimental variables with the network information we used for the algorithm that allocated individuals into groups and the traditional measures of social capital that seemed to have an impact on the effort decision.

The first panel in Table 8 shows the marginal effects of a partial proportional odds model for the decision to contribute to the lowest level of effort, the least risky decision and Pareto inefficient outcome. The negative coefficient for exposure means that the likelihood of coordinating on the least efficient equilibrium decreases when enrolment into the program is longer than a year. On average, beneficiaries that have been enrolled longer than a year are 23 percentage points less likely to choose $e=1$. The second panel in Table 8 shows the corresponding results for the decision to contribute to the highest level of effort, the riskiest decision and the Pareto dominant strategy. The positive coefficient for exposure confirms the finding from the first panel.

There are confounding factors that may affect the relation between the ability to coordinate as a measure of one dimension of social capital and the exposure to the program. In this section we will explore them.

\section{Other-regarding preferences}

The decision to exert the highest level of effort may be mediated by other-regarding preferences such as trust, altruism or reciprocity. For example, when people try to adopt a new norm, normative expectations may not be enough and individuals must also trust others to commit to the change. In fact, a player is aware that if she chooses the highest level of effort, any other player may obtain a higher payoff by deviating from that strategy. We use behavior in the Public Goods game as a proxy of such preferences. Specifications II, IIIb, IVb, IVd in Table 8 show that other-regarding preferences -measured as behavior in a cooperation game- is positively (negatively) related -although slightly significant- with a high (low) individual level of effort.

\footnotetext{
51 The proportional odds assumption states that our model with 3 categories is equivalent to 2 binary regressions with the critical assumption that the slope coefficients are identical across each regression.

${ }^{52}$ We used a Wald tests on each variable to see whether the variable meets the parallel-lines assumption. If the Wald test is statistically insignificant for one or more variables, the variable with the least significant value on the Wald test is constrained to have equal effects across equations. See Williams (2006).
} 
Table 8. Marginal effects of a partial proportional odds model for the lowest and highest individual level of effort (N=714)

\begin{tabular}{|c|c|c|c|c|c|c|c|c|}
\hline & I & II & IIIa & IIIb & IVa & IVb & IVc & IVd \\
\hline Independent Variable & Low & Low & Low & Low & Low & Low & Low & Low \\
\hline Beneficiary longer than a year (enrolment) & $\begin{array}{c}-0.23 * * * \\
(0.09)\end{array}$ & $\begin{array}{l}-0.24 * * * \\
(0.09)\end{array}$ & $\begin{array}{l}-0.23 * * * \\
(0.08)\end{array}$ & $\begin{array}{c}-0.24 * * * \\
(0.09)\end{array}$ & $\begin{array}{c}-0.24 * * * \\
(0.09)\end{array}$ & $\begin{array}{c}-0.25 * * * \\
(0.09)\end{array}$ & $\begin{array}{l}-0.24 * * * \\
(0.08)\end{array}$ & $\begin{array}{c}-0.25 * * * \\
(0.09)\end{array}$ \\
\hline Cooperation decision round 1 & & $\begin{array}{l}-0.08^{*} \\
(0.05)\end{array}$ & & $\begin{array}{l}-0.08 * \\
(0.05)\end{array}$ & & $\begin{array}{l}-0.08 * \\
(0.05)\end{array}$ & & $\begin{array}{l}-0.08^{*} \\
(0.05)\end{array}$ \\
\hline Cooperation decision round 2 & & $\begin{array}{c}0.03 \\
(0.05)\end{array}$ & & $\begin{array}{c}0.04 \\
(0.05)\end{array}$ & & $\begin{array}{c}0.03 \\
(0.05)\end{array}$ & & $\begin{array}{c}0.04 \\
(0.05)\end{array}$ \\
\hline Degree of Player (friends) & & & $\begin{array}{l}-0.03^{*} \\
(0.02)\end{array}$ & $\begin{array}{l}-0.03^{*} \\
(0.02)\end{array}$ & & & $\begin{array}{l}-0.03^{*} \\
(0.02)\end{array}$ & $\begin{array}{l}-0.03^{*} \\
(0.02)\end{array}$ \\
\hline Degree of Player (relatives) & & & $\begin{array}{c}0.04 \\
(0.04)\end{array}$ & $\begin{array}{r}0.04 \\
(0.04)\end{array}$ & & & $\begin{array}{c}0.03 \\
(0.04)\end{array}$ & $\begin{array}{r}0.04 \\
(0.04)\end{array}$ \\
\hline Degree of Player (acquaintances) & & & $\begin{array}{l}-0.01 \\
(0.02)\end{array}$ & $\begin{array}{l}-0.01 \\
(0.03)\end{array}$ & & & $\begin{array}{l}-0.01 \\
(0.02)\end{array}$ & $\begin{array}{l}-0.02 \\
(0.03)\end{array}$ \\
\hline Voted in presidential elections (2006) & & & & & $\begin{array}{c}0.06 * * \\
(0.03)\end{array}$ & $\begin{array}{c}0.06 * * \\
(0.03)\end{array}$ & $\begin{array}{c}0.06 * * \\
(0.03)\end{array}$ & $\begin{array}{c}0.06 * * \\
(0.03)\end{array}$ \\
\hline $\begin{array}{l}\text { Always or usually help anyone with money, } \\
\text { food or clothes }\end{array}$ & & & & & $\begin{array}{l}-0.07 \\
(0.06)\end{array}$ & $\begin{array}{l}-0.07 \\
(0.06)\end{array}$ & $\begin{array}{l}-0.07 \\
(0.06)\end{array}$ & $\begin{array}{l}-0.06 \\
(0.06)\end{array}$ \\
\hline Independent Variable & High & High & High & High & High & High & High & High \\
\hline Beneficiary longer than a year (enrolment) & $\begin{array}{c}0.32 * * * \\
(0.11)\end{array}$ & $\begin{array}{c}0.33 * * * \\
(0.12)\end{array}$ & $\begin{array}{c}0.32 * * * \\
(0.11)\end{array}$ & $\begin{array}{c}0.34 * * * \\
(0.12)\end{array}$ & $\begin{array}{l}0.33 * * * \\
(0.11)\end{array}$ & $\begin{array}{c}0.34 * * * \\
(0.12)\end{array}$ & $\begin{array}{c}0.33 * * * \\
(0.11)\end{array}$ & $\begin{array}{c}0.35 * * * \\
(0.12)\end{array}$ \\
\hline Cooperation decision round 1 & & $\begin{array}{c}0.11 * \\
(0.07)\end{array}$ & & $\begin{array}{l}0.12^{*} \\
(0.07)\end{array}$ & & $\begin{array}{c}0.11 * \\
(0.07)\end{array}$ & & $\begin{array}{l}0.12^{*} \\
(0.07)\end{array}$ \\
\hline Cooperation decision round 2 & & $\begin{array}{l}-0.05 \\
(0.07) \\
\end{array}$ & & $\begin{array}{l}-0.05 \\
(0.07)\end{array}$ & & $\begin{array}{c}-0.04 \\
(0.07)\end{array}$ & & $\begin{array}{l}-0.05 \\
(0.07)\end{array}$ \\
\hline Degree of Player (friends) & & & $\begin{array}{l}0.04 * \\
(0.02)\end{array}$ & $\begin{array}{c}0.05 * * \\
(0.02)\end{array}$ & & & $\begin{array}{l}0.04 * \\
(0.02)\end{array}$ & $\begin{array}{c}0.05 * * \\
(0.02)\end{array}$ \\
\hline Degree of Player (relatives) & & & $\begin{array}{l}-0.06 \\
(0.05)\end{array}$ & $\begin{array}{l}-0.06 \\
(0.05)\end{array}$ & & & $\begin{array}{l}-0.05 \\
(0.05)\end{array}$ & $\begin{array}{l}-0.05 \\
(0.05)\end{array}$ \\
\hline Degree of Player (acquaintances) & & & $\begin{array}{c}0.02 \\
(0.03)\end{array}$ & $\begin{array}{c}0.02 \\
(0.04)\end{array}$ & & & $\begin{array}{c}0.02 \\
(0.03)\end{array}$ & $\begin{array}{c}0.02 \\
(0.04)\end{array}$ \\
\hline Voted in presidential elections (2006) & & & & & $\begin{array}{c}-0.08 * * \\
(0.04)\end{array}$ & $\begin{array}{c}-0.08 * * \\
(0.04)\end{array}$ & $\begin{array}{l}-0.08^{*} \\
(0.04)\end{array}$ & $\begin{array}{c}-0.08 * * \\
(0.04)\end{array}$ \\
\hline $\begin{array}{l}\text { Always or usually help anyone with money, } \\
\text { food or clothes }\end{array}$ & & & & & $\begin{array}{c}0.10 \\
(0.08)\end{array}$ & $\begin{array}{c}0.10 \\
(0.08)\end{array}$ & $\begin{array}{c}0.10 \\
(0.08)\end{array}$ & $\begin{array}{c}0.09 \\
(0.08)\end{array}$ \\
\hline
\end{tabular}

Robust Standard errors that are clustered at the session level in parenthesis. * Significant at 10\%; ** significant at 5\%; *** significant at $1 \%$. Change in the predicted probabilities of holding each attitude for an increase of one unit of each independent variable, while holding all other independent variables constant at their means. 
We also explore how the decision to cooperate in rounds 1 and 2 is related to social capital measures ${ }^{53}$. In Table $\mathrm{A} 4 \mathrm{a}$ and $\mathrm{A} 4 \mathrm{~b}$ in the appendix, we report this relation for continuous (i.e. number of EC meetings, percentage of ML in the session and connectivity measures) and dummy survey measures, respectively ${ }^{54}$. Networks

A common limitation of most models of collective action is that they neglect that people can choose with whom they interact, which is known that is not random. Generally, people prefer to interact with people who are similar to them, and collective action is no exception. Empirical work has demonstrated that individuals who participate in collective action have more links to other participants than individuals who do not participate (Opp 1989).

In Table 8 specifications IIIa-IIIb the role of network information in the effort decision with and without cooperation. Regardless of the density of the network (i.e. number of friends, relatives and trustworthy acquaintances in the session are identified by the player), players who were enrolled into the program more than a year before chose the Pareto efficient level of effort (difference is significant at 1\%). While holding all other independent variables constant at their means, those players with an exposure of more than a year and having friends were $35 \%$ and 5\% more likely to choose the highest effort level, respectively. In addition, those players with an exposure of more than a year and having friends were $25 \%$ and 3\% less likely to choose the lowest effort level, respectively. This evidence on features of the network is consistent with the literature.

Once we control for the network features (specification IIIb), the decision to cooperate is also positive (negative) and significant for those who choose the high (low) level of effort, respectively. Other dimensions of social capital - Traditional survey measures

We include these relevant measures in specifications IVa-IVc in Table 8. Helping someone (which could be attributed to preferences for altruism) has the expected sign but is not significant: those who help

\footnotetext{
${ }^{53}$ To our knowledge the only evidence of positive correlation between behavior in the field and behavior in the lab (social capital related) in a PGG is Rustagi et al. (2010) on forest management activities and time spent on monitoring forest, De Oliveira et al. (2011) with amounts donated to neighborhood charities, Thoni et al. (2012) with survey measures on trust and fairness, and Barr et al. (2014) with elections on school authorities' accountability. With no correlation, Voors et al. (2011) with illegal commercial mining, logging, and hunting; illegal hunting of endangered species; support to forest conservation, Voors et al. (2012) with contribution to community project fund for the village and Cardenas et al. (2013) with participation in any social organization; attendance to their meetings; participation in their decision planning and hours in a month spent in them.

54 There is no relation between willingness to cooperate in the first round and traditional survey measures of social capital, with the exception of helping anyone with money, food or clothes, which constitutes altruistic behavior. The decision to cooperate in both rounds is positive and significantly related to the presence of at least one ML in the session. In contrast, we find that willingness to cooperate in the second round, which would measure not only an individual's preference to cooperate but also the effect of cheap talk, is positively related with declaring that the player (usually or always) helps others outside the household by offering the seat in the bus, carrying packages or groceries and taking care of the house or the children. Finally, willingness to cooperate is negatively related to attendance to the FA meetings.
} 
others are more likely to exert more effort. However, voting behavior is positively related to the likelihood of choosing the lowest level of effort. This result is consistent with the literature of social capital which states that trust in formal institutions and the rule of law is related with a higher voter turnout in elections, whereas voter turnout rates in communities with a weak rule of law and relevance of informal institutions or social norms are lower.

Table 9, presents three specifications in which we control for participants' basic socio-economic characteristics, experimental variables at the session, group and individual level, and the factors we considered in Table 8 .

Leadership

Social status is relevant in the creation and transmission of social norms (Richerson and Boyd 2008). In a coordination setting, a leader may have a strong influence on the equilibrium selection (Bala and Goyal 1998; Eckel and Wilson 2000, 2007). From Table 9, we find that only social capital measures related to the CCT program such as number of EC meetings and the percentage of ML in the session is significantly related to the level of effort. When including these measures in the analysis in specification VII (See Table $10 \mathrm{~b}$ ) they don't affect the effort decision. For example, contrary to behavior from previous coordination games in the lab (Foss 2001; Gillet et al. 2011; Brandts et al. 2015) we don't find a relation between being a ML, or the presence of a ML in the group, and the effort decision.

$\underline{\text { Basic demographics and wealth }}$

We also consider the economic approach to social capital (Glaeser et al. 2002; Polania-Reyes 2005) and examine the role of socio-economic characteristics at household and individual level in the individual effort decision. Table 9 reports the effect of the exposure to the program on the effort decision, when controlling for these individual characteristics. Overall, the effect is consistent with our previous specifications.

Specifications V-VII in Table10 a report the marginal effects of different socio-economic dimensions. First it reports individual demographic characteristics such as being a woman, age, level of education, number of years living in the neighborhood, whether the player is displaced, is the head of the household, has a partner or is beneficiary of another program different from FA. Then it reports housing conditions such as the number of people per room, if the housing is owned, if the housing does have electricity, water pipe access and sewage. Finally it reports wealth measured as assets ${ }^{55}$, household income and household perception of wealth with respect to other households in the neighborhood.

The only characteristics with significant marginal effects at both levels of effort are having a landline and the individual perception of wealth. Having a landline will increase the probability to choose

\footnotetext{
55 The assets are landline, cellphone, sound-player and DVD player.
} 
the lowest level of effort by $7 \%$ and decrease the probability of choosing the highest level of effort by $11 \%$. This result would imply that having no land line would provide an incentive to strengthen their communication with others by more interactions or other means or the habit of effort with sometimes no reward by the player. In addition, an increasing perception of how rich is the household compared to others in the community will decrease the likelihood of the ability to coordinate.

Table 9. Marginal effects of a partial proportional odds model for the lowest and highest individual level of effort

\begin{tabular}{|c|c|c|c|}
\hline & $\mathbf{V}$ & VI & VII \\
\hline Independent Variable & Low & Low & Low \\
\hline Beneficiary longer than a year (enrolment) & $\begin{array}{c}-0.19 * * * \\
(0.08)\end{array}$ & $\begin{array}{l}-0.29 * * * \\
(0.08)\end{array}$ & $\begin{array}{c}-0.30 * * * \\
(0.07)\end{array}$ \\
\hline Cooperation decision round 1 & & & $\begin{array}{l}-0.06 \\
(0.04)\end{array}$ \\
\hline Cooperation decision round 2 & & & $\begin{array}{c}0.02 \\
(0.05)\end{array}$ \\
\hline Degree of Player (friends) & & & $\begin{array}{l}-0.03 * * \\
(0.02)\end{array}$ \\
\hline Degree of Player (relatives) & & & $\begin{array}{c}0.03 \\
(0.04)\end{array}$ \\
\hline Degree of Player (acquaintances) & & & $\begin{array}{c}0.00 \\
(0.03)\end{array}$ \\
\hline Independent Variable & High & High & High \\
\hline Beneficiary longer than a year (enrolment) & $\begin{array}{c}0.27 * * * \\
(0.11)\end{array}$ & $\begin{array}{l}0.43^{* * *} \\
(0.1)\end{array}$ & $\begin{array}{c}0.45 * * * \\
(0.1)\end{array}$ \\
\hline Cooperation decision round 1 & & & $\begin{array}{c}0.09 \\
(0.06)\end{array}$ \\
\hline Cooperation decision round 2 & & & $\begin{array}{l}-0.03 \\
(0.07)\end{array}$ \\
\hline Degree of Player (friends) & & & $\begin{array}{l}0.05 * * \\
(0.03)\end{array}$ \\
\hline Degree of Player (relatives) & & & $\begin{array}{l}-0.05 \\
(0.05)\end{array}$ \\
\hline Degree of Player (acquaintances) & & & $\begin{array}{c}0.00 \\
(0.04)\end{array}$ \\
\hline Basic characteristics & Yes & Yes & Yes \\
\hline Experimental variables & No & Yes & Yes \\
\hline CCT measures of Social capital & No & No & Yes \\
\hline Observations & 712 & 712 & 712 \\
\hline
\end{tabular}

Robust Standard errors that are clustered at the session level in parenthesis. * Significant at $10 \%$; ** significant at $5 \% ; * * *$ significant at $1 \%$.

\section{Experimental session variables}

Specifications VI in Table 6.2 and Table 6.4 include session variables such as whether there is a man in the session, whether the player understood perfectly the coordination game, a dummy of one of the experimenters and the size of the session. In addition, given the possibility of contamination among subjects of different sessions since participants in a session could talk to participants of the next session on their way in. Despite, our effort in avoiding that king of contamination effects in the field, we control for this possibility with the average level of effort in previous two sessions and a dummy whether that 
session was the first one on that day.

Table 10 a Control variables in Table 9 Marginal effects of a partial proportional odds model for the lowest and highest level of effort - Basic Characteristics

\begin{tabular}{|c|c|c|c|c|c|c|}
\hline & $\mathbf{V}$ & VI & VII & $\mathbf{V}$ & VI & VII \\
\hline Independent Variable & Low & Low & Low & High & High & High \\
\hline 1 if the player is a woman & $\begin{array}{l}-0.15 \\
(0.15)\end{array}$ & $\begin{array}{l}-0.07 \\
(0.1)\end{array}$ & $\begin{array}{l}-0.04 \\
(0.11)\end{array}$ & $\begin{array}{c}0.22 \\
(0.21)\end{array}$ & $\begin{array}{c}0.1 \\
(0.15)\end{array}$ & $\begin{array}{c}0.06 \\
(0.16)\end{array}$ \\
\hline Age & $\begin{array}{c}0.00 \\
(0.00)\end{array}$ & $\begin{array}{c}0.00 \\
(0.00)\end{array}$ & $\begin{array}{c}0.00 \\
(0.00)\end{array}$ & $\begin{array}{c}0.00 \\
(0.00)\end{array}$ & $\begin{array}{c}0.00 \\
(0.00)\end{array}$ & $\begin{array}{c}0.00 \\
(0.00)\end{array}$ \\
\hline Level of education ( 0 to 5 ) & $\begin{array}{c}0.01 \\
(0.01)\end{array}$ & $\begin{array}{l}0.02 * \\
(0.01)\end{array}$ & $\begin{array}{c}0.02 \\
(0.01)\end{array}$ & $\begin{array}{l}-0.02 \\
(0.01)\end{array}$ & $\begin{array}{l}-0.02 * \\
(0.01)\end{array}$ & $\begin{array}{l}-0.03 \\
(0.02)\end{array}$ \\
\hline Number of years living in the neighborhood & $\begin{array}{c}0.00 \\
(0.00)\end{array}$ & $\begin{array}{c}0.00 \\
(0.00)\end{array}$ & $\begin{array}{c}0.00 \\
(0.00)\end{array}$ & $\begin{array}{c}0.00 \\
(0.00)\end{array}$ & $\begin{array}{c}0.00 \\
(0.00)\end{array}$ & $\begin{array}{c}0.00 \\
(0.00)\end{array}$ \\
\hline 1 if the player is displaced (self-declared) & $\begin{array}{c}0.01 \\
(0.05)\end{array}$ & $\begin{array}{c}0.02 \\
(0.05)\end{array}$ & $\begin{array}{c}0.01 \\
(0.05)\end{array}$ & $\begin{array}{l}-0.02 \\
(0.07)\end{array}$ & $\begin{array}{l}-0.02 \\
(0.07)\end{array}$ & $\begin{array}{l}-0.02 \\
(0.08)\end{array}$ \\
\hline 1 if the player is the head of household & $\begin{array}{c}0.00 \\
(0.03)\end{array}$ & $\begin{array}{c}0.02 \\
(0.03)\end{array}$ & $\begin{array}{c}0.01 \\
(0.03)\end{array}$ & $\begin{array}{c}0.00 \\
(0.04)\end{array}$ & $\begin{array}{c}-0.03 \\
(0.04)\end{array}$ & $\begin{array}{l}-0.02 \\
(0.05)\end{array}$ \\
\hline 1 if the player has a partner & $\begin{array}{l}-0.03 \\
(0.04)\end{array}$ & $\begin{array}{l}-0.02 \\
(0.04)\end{array}$ & $\begin{array}{l}-0.02 \\
(0.04)\end{array}$ & $\begin{array}{c}0.05 \\
(0.05)\end{array}$ & $\begin{array}{c}0.02 \\
(0.06)\end{array}$ & $\begin{array}{c}0.03 \\
(0.06)\end{array}$ \\
\hline Number of people per room & $\begin{array}{l}-0.01 \\
(0.01)\end{array}$ & $\begin{array}{l}-0.01 \\
(0.01)\end{array}$ & $\begin{array}{c}0.00 \\
(0.01)\end{array}$ & $\begin{array}{c}0.01 \\
(0.01)\end{array}$ & $\begin{array}{c}0.01 \\
(0.01)\end{array}$ & $\begin{array}{c}0.01 \\
(0.01)\end{array}$ \\
\hline 1 if the player has her own housing & $\begin{array}{l}-0.02 \\
(0.03)\end{array}$ & $\begin{array}{l}-0.02 \\
(0.02)\end{array}$ & $\begin{array}{l}-0.01 \\
(0.03)\end{array}$ & $\begin{array}{c}0.03 \\
(0.04)\end{array}$ & $\begin{array}{c}0.03 \\
(0.04)\end{array}$ & $\begin{array}{c}0.02 \\
(0.04)\end{array}$ \\
\hline 1 if the player's home has no electricity & $\begin{array}{l}-0.01 \\
(0.07)\end{array}$ & $\begin{array}{c}0.02 \\
(0.07)\end{array}$ & $\begin{array}{c}0.03 \\
(0.06)\end{array}$ & $\begin{array}{l}0.01 \\
(0.1)\end{array}$ & $\begin{array}{l}-0.02 \\
(0.11)\end{array}$ & $\begin{array}{l}-0.04 \\
(0.09)\end{array}$ \\
\hline 1 if the player has a landline & $\begin{array}{c}0.06^{* *} \\
(0.03)\end{array}$ & $\begin{array}{c}0.07 * * \\
(0.03)\end{array}$ & $\begin{array}{c}0.07 * * \\
(0.03)\end{array}$ & $\begin{array}{c}-0.09^{* *} . \\
(0.04)\end{array}$ & $\begin{array}{l}-0.11 * * \\
(0.05)\end{array}$ & $\begin{array}{c}-0.11 * * \\
(0.05)\end{array}$ \\
\hline 1 if the player has a cellphone & $\begin{array}{l}-0.01 \\
(0.03)\end{array}$ & $\begin{array}{c}0.01 \\
(0.03)\end{array}$ & $\begin{array}{c}0.00 \\
(0.03)\end{array}$ & $\begin{array}{c}0.01 \\
(0.04)\end{array}$ & $\begin{array}{l}-0.02 \\
(0.05)\end{array}$ & $\begin{array}{l}-0.01 \\
(0.05)\end{array}$ \\
\hline 1 if the player's home has water pipe access & $\begin{array}{c}-0.07 * * \\
(0.04)\end{array}$ & $\begin{array}{l}-0.05 \\
(0.03)\end{array}$ & $\begin{array}{l}-0.06 \\
(0.04)\end{array}$ & $\begin{array}{c}0.11 * * \\
(0.05)\end{array}$ & $\begin{array}{c}0.08 \\
(0.05)\end{array}$ & $\begin{array}{c}0.09 \\
(0.06)\end{array}$ \\
\hline 1 if the player's home has sewage & $\begin{array}{c}0.02 \\
(0.03)\end{array}$ & $\begin{array}{l}-0.01 \\
(0.03)\end{array}$ & $\begin{array}{l}-0.01 \\
(0.03)\end{array}$ & $\begin{array}{l}-0.03 \\
(0.04)\end{array}$ & $\begin{array}{c}0.01 \\
(0.05)\end{array}$ & $\begin{array}{c}0.02 \\
(0.05)\end{array}$ \\
\hline $\begin{array}{l}1 \text { if She has received (different from FA) any other } \\
\text { government aid }\end{array}$ & $\begin{array}{l}-0.02 \\
(0.02)\end{array}$ & $\begin{array}{l}-0.04 \\
(0.03)\end{array}$ & $\begin{array}{l}-0.03 \\
(0.03)\end{array}$ & $\begin{array}{l}0.03 \\
(0.03)\end{array}$ & $\begin{array}{c}0.06 \\
(0.04)\end{array}$ & $\begin{array}{c}0.04 \\
(0.04)\end{array}$ \\
\hline $\begin{array}{l}1 \text { if Perceives that } \mathrm{HH} \text { income is above the highest } \\
\text { possible }\end{array}$ & $\begin{array}{c}-0.33 * * * \\
(0.1)\end{array}$ & $\begin{array}{l}0.25 * * * \\
(0.07)\end{array}$ & $\begin{array}{l}-0.06 \\
(0.07)\end{array}$ & $\begin{array}{c}0.1 \\
(0.12)\end{array}$ & $\begin{array}{l}0.01 \\
(0.1)\end{array}$ & $\begin{array}{l}0.09 \\
(0.1)\end{array}$ \\
\hline 1 if Perceives that $\mathrm{HH}$ income is above the average & $\begin{array}{l}-0.04 \\
(0.06)\end{array}$ & $\begin{array}{l}-0.01 \\
(0.05)\end{array}$ & $\begin{array}{l}-0.01 \\
(0.05)\end{array}$ & $\begin{array}{l}0.06 \\
(0.08)\end{array}$ & $\begin{array}{c}0.02 \\
(0.08)\end{array}$ & $\begin{array}{c}0.02 \\
(0.08)\end{array}$ \\
\hline 1 if the $\mathrm{HH}$ has a sound player & $\begin{array}{c}0.00 \\
(0.03)\end{array}$ & $\begin{array}{l}-0.01 \\
(0.03)\end{array}$ & $\begin{array}{c}0.00 \\
(0.03)\end{array}$ & $\begin{array}{l}0.00 \\
(0.04)\end{array}$ & $\begin{array}{c}0.01 \\
(0.04)\end{array}$ & $\begin{array}{c}0.00 \\
(0.04)\end{array}$ \\
\hline HH income per capita & $\begin{array}{c}0.00 \\
(0.00)\end{array}$ & $\begin{array}{c}0.00 \\
(0.00)\end{array}$ & $\begin{array}{c}0.00 \\
(0.00)\end{array}$ & $\begin{array}{c}0.00 \\
(0.00)\end{array}$ & $\begin{array}{c}0.00 \\
(0.00)\end{array}$ & $\begin{array}{c}0.00 \\
(0.00)\end{array}$ \\
\hline 1 if the $\mathrm{HH}$ has a DVD player & $\begin{array}{c}0.01 \\
(0.03)\end{array}$ & $\begin{array}{c}0.01 \\
(0.03)\end{array}$ & $\begin{array}{c}0.01 \\
(0.03)\end{array}$ & $\begin{array}{c}-0.01 \\
(0.05)\end{array}$ & $\begin{array}{l}-0.01 \\
(0.04)\end{array}$ & $\begin{array}{l}-0.01 \\
(0.04)\end{array}$ \\
\hline Basic characteristics & Yes & Yes & Yes & Yes & Yes & Yes \\
\hline Expert & No & Yes & Yes & No & Yes & Yes \\
\hline CCT measu & No & No & Yes & No & No & Yes \\
\hline Observations & 712 & 712 & 712 & 712 & 712 & 712 \\
\hline
\end{tabular}

Robust Standard errors that are clustered at the session level in parenthesis. * Significant at 10\%;** 5\%; *** 1\%. 
Table $10 \mathrm{~b}$ Control variables in Table 9 Marginal effects of a partial proportional odds model for the lowest and highest level of effort -Experimental variables and CCT measures of Social Capital

\begin{tabular}{|c|c|c|c|c|}
\hline & VI & VII & VI & VII \\
\hline Independent Variable & Low & Low & High & High \\
\hline 1 if there is at least one man in the group & $\begin{array}{c}0.09 \\
(0.09)\end{array}$ & $\begin{array}{c}0.12 \\
(0.09)\end{array}$ & $\begin{array}{l}-0.14 \\
(0.13)\end{array}$ & $\begin{array}{l}-0.18 \\
(0.14)\end{array}$ \\
\hline 1 if the player understood the activity perfectly & $\begin{array}{l}-0.02 \\
(0.02)\end{array}$ & $\begin{array}{l}-0.02 \\
(0.03)\end{array}$ & $\begin{array}{c}0.02 \\
(0.04)\end{array}$ & $\begin{array}{c}0.02 \\
(0.04)\end{array}$ \\
\hline 1 if Experimenter $n^{\circ} 2$ (female) in 2008 & $\begin{array}{c}-0.18^{* * *} \\
(0.09)\end{array}$ & $\begin{array}{c}-0.17 * * \\
(0.09)\end{array}$ & $\begin{array}{c}0.26 * * \\
(0.13)\end{array}$ & $\begin{array}{l}0.26 * * \\
(0.13)\end{array}$ \\
\hline Number of players in session & $\begin{array}{c}0.09 * * \\
(0.04)\end{array}$ & $\begin{array}{c}0.08^{* *} \\
(0.04)\end{array}$ & $\begin{array}{c}-0.13 * * * \\
(0.05)\end{array}$ & $\begin{array}{c}-0.13 * * * \\
(0.05)\end{array}$ \\
\hline 1 if First session in the day & $\begin{array}{l}-0.03 \\
(0.08)\end{array}$ & $\begin{array}{l}-0.02 \\
(0.08)\end{array}$ & $\begin{array}{c}0.05 \\
(0.13)\end{array}$ & $\begin{array}{c}0.03 \\
(0.12)\end{array}$ \\
\hline Average level of effort in the last two sessions a & $\begin{array}{c}-0.1 \\
(0.11)\end{array}$ & $\begin{array}{c}-0.11 \\
(0.11)\end{array}$ & $\begin{array}{c}0.14 \\
(0.16)\end{array}$ & $\begin{array}{c}0.16 \\
(0.16)\end{array}$ \\
\hline 1 if player is chosen as leader by anyone in the group & & $\begin{array}{c}0.03 \\
(0.05)\end{array}$ & & $\begin{array}{l}-0.05 \\
(0.08)\end{array}$ \\
\hline 1 if player is a ML (self-declared) & & $\begin{array}{c}-0.02 \\
(0.06)\end{array}$ & & $\begin{array}{c}0.02 \\
(0.09)\end{array}$ \\
\hline 1 if there is at least $1 \mathrm{ML}$ in the group & & $\begin{array}{l}-0.02 \\
(0.04) \\
\end{array}$ & & $\begin{array}{c}0.03 \\
(0.07) \\
\end{array}$ \\
\hline Basic characteristics & Yes & Yes & Yes & Yes \\
\hline Experimental variables & Yes & Yes & Yes & Yes \\
\hline CCT measures of social capital & No & Yes & No & Yes \\
\hline Observations & 712 & 712 & 712 & 712 \\
\hline
\end{tabular}

Robust Standard errors that are clustered at the session level in parenthesis. ${ }^{a}$ Average deviation from the neighborhood mean of the average effort in the previous 2 sessions * Significant at 10\%;** significant at 5\%; *** significant at $1 \%$.

\section{Concluding remarks}

There is an increasing interest in measuring economic preferences using both choice experiments and surveys in order to identify relationships and causal effects of economic features related to prosocial behavior. However, the experimental literature on social capital has focused entirely on the dimension of cooperation and trust, omitting coordination. The main contribution of this study is the use of a new experimental measure of social capital based on the behavior in a coordination game with social networks. We also use other two well-studied measures in the literature (i.e. cooperation in a Public Goods game and traditional survey measures of social capital).

Surveys record stated preferences while experiment outcomes provide revealed preferences. The experimental literature on economic experiments and surveys does not find a consistent answer on whether these two are positively correlated ${ }^{56}$. Our study is in line with the literature in this sense.

Many CCT programs have important social components and, therefore, can be related to social

\footnotetext{
${ }^{56}$ On one hand Gaechter et al. (2004) and Capra et al. (2008) find a positive correlation between stated and revealed preferences in the public goods game and trust game. On the other hand Cardenas et al. (2013) find no evidence of correlation between participation in a charity and contribution in a public goods game.
} 
capital measures. Our hypothesis is that coordination is an important aspect of social capital, which in our case is strongly affected by a CCT program. This study calls attention to the coordination dimension of social capital. We find a positive and significant relation between the individual effort decision and the exposure to a CCT program which has a social capital component. This relationship is consistent when controlling for all possible confounding factors. We also find that the degree of friends in the network is key to the ability to coordinate on the Pareto-efficient equilibrium ${ }^{57}$.

Unfortunately our study is only a quasi-experiment, establishing the relation (but not the causation) between exposure to the program and ability to coordinate on the most efficient equilibrium. We do find the relation to be robust to controlling for potential confounding factors.

We use a Quantal Response non-Equilibrium approach to support the validity of our minimum effort game as an instrument to measure a social norm in our particular sample. The most important question to ask about norms is what system of beliefs supports and defines norms. Once we understand these beliefs, we can tell whether the behaviors that we observe are norm-driven or not, measure the consistency between beliefs and behavior under different conditions, and make predictions about future behaviors (Bicchieri, 2014). We find that the theoretical prediction for long exposure beneficiaries is similar to the observed data ${ }^{58}$.

\section{Acknowledgements}

I thank my advisors Orazio Attanasio and Syngjoo Choi for their guidance and support. I also thank Antonio Cabrales, Juan Camilo Cárdenas, Antonio Guarino, David Echeverry and Simon Gaechter, as well as seminar participants at University of San Francisco, EDepo seminar and UC Berkeley for their helpful comments and feedback. We thank Liliam Puello and Beatriz Jimenez from the local office of Familias en Acción in Cartagena, Hernando Sánchez from the national office of Familias en Acción and assistants Patricia Padilla and Vivian Rodríguez. The experiments and analysis reported here were sponsored by the European Commission, the

Institute for Fiscal Studies and Corpovisionarios.

\footnotetext{
${ }^{57}$ Table A.3 in the appendix complements our analysis. We find a positive relation between exposure to the program and participation in neighborhood and program meetings as well as voting in presidential elections and participating in bonding and bridging associations (as defined by Woolcook, 1998).

${ }^{58} \mathrm{An}$ interesting addition could be to use the QRE approach and estimate a structural model using a groupcontingent social preference model where an agent maximizes a weighted sum of her own and others' payoffs, with weighting dependent on a group category of the other players ((R. Chen and Chen 2011; McLeish and Oxoby 2011; Y. Chen et al. 2014). Those beneficiaries who have been exposed for a longer time are able to identify themselves as a group and behave 'altruistically' towards one another.
} 


\section{References}

Adato, M., Hoddinott, J., \& Haddad, L. J. (2005). Power, politics, and performance: community participation in South African public works programs (Vol. 143): Intl Food Policy Res Inst.

Adler, P. S., \& Kwon, S.-W. (2002). Social capital: Prospects for a new concept. Academy of management review, 27(1), 17-40.

Advani, A., \& Malde, B. (2014). Empirical methods for networks data: Social effects, network formation and measurement error. In IFS (Ed.), Working papers: University College London.

Altonji, J. G., Conley, T., Elder, T. E., \& Taber, C. R. (2013). Methods for Using Selection on Observed Variables to Address Selection on Unobserved Variables.

Altonji, J. G., Elder, T. E., \& Taber, C. R. (2005). Selection on Observed and Unobserved Variables: Assessing the Effectiveness of Catholic Schools. Journal of political Economy, 113(1), 151-184, doi: $10.1086 / 426036$.

Altonji, J. G., Elder, T. E., \& Taber, C. R. (2008). Using Selection on Observed Variables to Assess Bias from Unobservables When Evaluating Swan-Ganz Catheterization. American Economic Review, 98(2), 345-350, doi:doi: 10.1257/aer.98.2.345.

Alzua, M. L., Cardenas, J. C., \& Djebbari, H. (2014). Community mobilization around social dilemmas: evidence from lab experiments in rural Mali. In U. N. d. L. Plata (Ed.), (Vol. 0160).

Anderson, L. R., Mellor, J. M., \& Milyo, J. (2004). Social capital and contributions in a public-goods experiment. American Economic Review, 373-376.

Anderson, S. P., Goeree, J. K., \& Holt, C. A. (2001). Minimum-effort coordination games: Stochastic potential and logit equilibrium. Games and Economic Behavior, 34(2), 177-199.

Attanasio, O., Barr, A., Cardenas, J. C., Genicot, G., \& Meghir, C. (2012). Risk pooling, risk preferences, and social networks. American Economic Journal: Applied Economics, 4(2), 134-167.

Attanasio, O., Pellerano, L., \& Polania-Reyes, S. (2009). Building Trust? Conditional Cash Transfer Programmes and Social Capital*. Fiscal Studies, 30(2), 139-177.

Attanasio, O., Polania-Reyes, S., \& Pellerano, L. (2015). Building social capital: Conditional cash transfers and cooperation. Journal of Economic Behavior \& Organization, 118, 22-39, doi:http://dx.doi.org/10.1016/j.jebo.2015.04.004.

Avdeenko, A., \& Gilligan, M. J. (2014). International interventions to build social capital: evidence from a field experiment in Sudan. World Bank Policy Research Working Paper(6772).

Axelrod, R. (1986). An evolutionary approach to norms. American political science review, 80(04), 10951111.

Bala, V., \& Goyal, S. (1998). Learning from Neighbours. The Review of Economic Studies, 65(3), 595621.

Barr, A., Mugisha, F., Serneels, P., \& Zeitlin, A. (2012). Information and collective action in community monitoring of schools: Field and lab experimental evidence from Uganda.

Barr, A., Packard, T., \& Serra, D. (2014). Participatory accountability and collective action: Experimental evidence from Albania. European Economic Review, 68, 250-269.

Bass, B. M. (1991). From transactional to transformational leadership: Learning to share the vision. Organizational dynamics, 18(3), 19-31.

Bernheim, B. D. (1994). A theory of conformity. Journal of political Economy, 841-877.

Berninghaus, S. K., \& Ehrhart, K.-M. (1998). Time horizon and equilibrium selection in tacit coordination games: Experimental results. Journal of Economic Behavior \& Organization, 37(2), 231-248.

Berninghaus, S. K., \& Ehrhart, K.-M. (2001). Coordination and information: Recent experimental evidence. Economics Letters, 73(3), 345-351.

Bicchieri, C. (1993). Rationality and coordination. : Cambridge University Press.

Bicchieri, C. (2005). The grammar of society: The nature and dynamics of social norms: Cambridge University Press. 
Bicchieri, C. (2014). Norms in the Wild: How to Diagnose, Measure and Change Social Norms: Cambridge: Cambridge University Press.

Bicchieri, C., \& Muldoon, R. (2014). Social Norms. In E. N. Zalta (Ed.), The Stanford Encyclopedia of Philosophy (Spring ed.).

Blume, A., \& Ortmann, A. (2007). The effects of costless pre-play communication: Experimental evidence from games with Pareto-ranked equilibria. Journal of Economic theory, 132(1), 274290.

Bornstein, G., Gneezy, U., \& Nagel, R. (2002). The effect of intergroup competition on group coordination: An experimental study. Games and Economic Behavior, 41(1), 1-25.

Boschini, A., Dreber, A., Von Essen, E., Muren, A., \& Ranehill, E. (2014). Gender and economic preferences in a large random and representative sample. Available at SSRN 2443315.

Bosworth, S. J. (2013). Social capital and equilibrium selection in Stag Hunt games. Journal of Economic Psychology, 39, 11-20.

Bowles, S. (2004). Microeconomics: Behavior, Institutions, and Evolution: Behavior, Institutions, and Evolution: Princeton University Press.

Brandts, J., \& Cooper, D. J. (2006). A Change Would Do You Good .... An Experimental Study on How to Overcome Coordination Failure in Organizations. American Economic Review, 96(3), 669-693, doi:doi: 10.1257/aer.96.3.669.

Brandts, J., \& Cooper, D. J. (2007). It's what you say, not what you pay: an experimental study of manager-employee relationships in overcoming coordination failure. Journal of the European Economic Association, 5(6), 1223-1268.

Brandts, J., Cooper, D. J., \& Fatas, E. (2007). Leadership and overcoming coordination failure with asymmetric costs. Experimental Economics, 10(3), 269-284.

Brandts, J., Cooper, D. J., \& Weber, R. A. (2015). Legitimacy, Communication, and Leadership in the Turnaround Game. Management Science, 61(11), 2627-2645, doi:doi:10.1287/mnsc.2014.2021.

Brandts, J., \& MacLeod, W. B. (1995). Equilibrium selection in experimental games with recommended play. Games and Economic Behavior, 11(1), 36-63.

Brooks, B. A., Hoff, K., \& Pandey, P. (2015). Culture and the Efficiency of Coordination: Experiments with High- and Low-Caste Men in Rural India.

Brunie, A. (2009). Meaningful distinctions within a concept: Relational, collective, and generalized social capital. Social science research, 38(2), 251-265.

Bryant, J. (1983). A Simple Rational Expectations Keynes-Type Model. The Quarterly Journal of Economics, 98(3), 525-528.

Burton, A., Loomes, G., \& Sefton, M. (2005). Communication and Efficiency in Coordination Game Experiments. In J. Morgan (Ed.), Experimental and Behavioral Economics (Advances in Applied Microeconomics) (Vol. 13, pp. 63-85).

Camerer, C. (2003). Behavioral game theory: Experiments in strategic interaction: Princeton University Press.

Camerer, C., \& Knez, M. (1994). Creating expectational assets in the laboratory: Weakest link coordination games. Strategic Management Journal, 15, 101-119.

Candelo, N., \& Polania-Reyes, S. (2008). Methodological steps for an experimental design to measure social capital and collective action in six Latinamerican cities. [Pasos metodológicos de un diseño experimental para medir capital social y acción colectiva en seis ciudades latinoamericanas] In U. o. L. Andes (Ed.), Working paper CEDE.

Capra, C. M., Lanier, K., \& Meer, S. (2008). Attitudinal and Behavioral Measures of trust: a NewComparison. Department of Economics, Emory University, Mimeo.

Cardenas, J. C., Chong, A., \& Ñopo, H. (2013). Stated social behavior and revealed actions: Evidence from six Latin American countries. Journal of Development Economics, 104, 16-33.

Cardenas, J. C., Chong, A., Nopo, H., Horowitz, A. W., \& Lederman, D. (2009). To What Extent Do Latin Americans Trust, Reciprocate, and Cooperate? Evidence from Experiments in Six Latin American Countries [with Comments]. Economia, 9(2), 45-94. 
Carlsson, H., \& Van Damme, E. (1993). Global games and equilibrium selection. Econometrica: Journal of the Econometric Society, 989-1018.

Carpenter, J. (2002). Measuring social capital: Adding field experimental methods to the analytical toolbox (Social capital and economic development: Well-being in developing countries): Edward Elgar.

Carpenter, J., Daniere, A. G., \& Takahashi, L. M. (2004). Cooperation, trust, and social capital in Southeast Asian urban slums. Journal of Economic Behavior \& Organization, 55(4), 533-551.

Cartwright, E., Gillet, J., \& Van Vugt, M. (2013). Leadership by Example in the Weak-Link Game. Economic Inquiry, 51(4), 2028-2043.

Cason, T. N., Sheremeta, R. M., \& Zhang, J. (2012). Communication and efficiency in competitive coordination games. Games and Economic Behavior, 76(1), 26-43.

Cassar, A. (2007). Coordination and cooperation in local, random and small world networks: Experimental evidence. Games and Economic Behavior, 58(2), 209-230.

Chakravarty, S., Fonseca, M., Ghosh, S., \& Marjit, S. (2015). Religious fragmentation, social identity and cooperation: Evidence from an artefactual field experiment in India. In D. o. E. Exeter University (Ed.), Discussion Papers.

Charness, G., Feri, F., Meléndez-Jiménez, M. A., \& Sutter, M. (2014). Experimental Games on Networks: Underpinnings of Behavior and Equilibrium Selection. Econometrica, 82(5), 1615-1670, doi:10.3982/ecta11781.

Charness, G., \& Rabin, M. (2002). Understanding social preferences with simple tests. Quarterly journal of Economics, 117(3), 817-869.

Chen, R., \& Chen, Y. (2011). The Potential of Social Identity for Equilibrium Selection. American Economic Review, 101(6), 2562-2589, doi:doi: 10.1257/aer.101.6.2562.

Chen, Y., Li, S. X., Liu, T. X., \& Shih, M. (2014). Which hat to wear? Impact of natural identities on coordination and cooperation. Games and Economic Behavior, 84, 58-86.

Choi, S., \& Lee, J. (2014). Communication, coordination, and networks. Journal of the European Economic Association, 12(1), 223-247.

Christoforou, A., \& Davis, J. B. (2014). Social capital and economics: Social values, Power, and social Identity (Vol. 20): Routledge.

Cialdini, R. B., \& Trost, M. R. (1998). Social influence: Social norms, conformity and compliance. In G. Lindzey, D. Gilbert, \& S. T. Fiske (Eds.), The handbook of social psychology: Oxford University Press.

Clark, K., Kay, S., \& Sefton, M. (2001). When are Nash equilibria self-enforcing? An experimental analysis. International Journal of Game Theory, 29(4), 495-515.

Coleman, J. S. (1987). Norms as social capital. In G. Radnitzky, \& P. Bernholz (Eds.), Economic imperialism (pp. 133-155). New York: Paragon.

Coleman, J. S. (1988). Social Capital in the Creation of Human Capital. American journal of sociology, 94, S95-S120.

Coleman, J. S. (1994). Foundations of social theory: Harvard university press.

Cooper, R. (1999). Coordination games: Cambridge University Press.

Dasgupta, P., \& Serageldin, I. (2001). Social capital: a multifaceted perspective: World Bank Publications.

De Oliveira, A. C., Croson, R. T., \& Eckel, C. (2011). The giving type: Identifying donors. Journal of Public Economics, 95(5), 428-435.

Devetag, G., \& Ortmann, A. (2007). When and why? A critical survey on coordination failure in the laboratory. Experimental Economics, 10(3), 331-344.

DNP (2010). The journey: ten years of Familias en Acción [El camino recorrido: Diez Años de Familias en Acción]. In D. N. d. Planeación. (Ed.). Bogota, Colombia.

Dufwenberg, M., \& Gneezy, U. (2005). Gender \& coordination. In Experimental business research (pp. 253-262): Springer. 
Dugar, S. (2010). Nonmonetary sanctions and rewards in an experimental coordination game. Journal of Economic Behavior \& Organization, 73(3), 377-386.

Eckel, C. C., \& Wilson, R. K. Social learning in a social hierarchy: An experimental study. In American Association for the Advancement of Science. Convention in Washington, DC, 2000 (pp. 16-22)

Eckel, C. C., \& Wilson, R. K. (2007). Social learning in coordination games: does status matter? Experimental Economics, 10(3), 317-329.

Ellickson, R. C. (1991). Order without law: How neighbors settle disputes: Harvard University Press.

Engelmann, D., \& Normann, H.-T. (2010). Maximum effort in the minimum-effort game. Experimental Economics, 13(3), 249-259.

Erkut, H., Nosenzo, D., \& Sefton, M. (2015). Identifying social norms using coordination games: Spectators vs. stakeholders. Economics Letters, 130, 28-31, doi:http://dx.doi.org/10.1016/j.econlet.2015.02.021.

Fearon, J. D., Humphreys, M., \& Weinstein, J. M. (2009). Can Development Aid Contribute to Social Cohesion after Civil War? Evidence from a Field Experiment in Post-conflict Liberia. American Economic Review, 99(2), 287-291, doi:doi: 10.1257/aer.99.2.287.

Fehr, E., \& Schmidt, K. M. (1999). A Theory of Fairness, Competition, and Cooperation. The Quarterly Journal of Economics, 114(3), 817-868, doi:10.1162/003355399556151.

Fishbein, M., \& Ajzen, I. (2011). Predicting and changing behavior: The reasoned action approach: Taylor \& Francis.

Foss, N. J. (2001). Leadership, beliefs and coordination: An explorative discussion. Industrial and corporate change, 10(2), 357-388.

Fukuyama, F. (2001). Social capital, civil society and development. Third world quarterly, 22(1), 7-20.

Gaechter, S., Herrmann, B., \& Thoni, C. (2004). Trust, voluntary cooperation, and socio-economic background: survey and experimental evidence. Journal of Economic Behavior \& Organization, 55(4), 505-531.

Gauthier, D. P. (1986). Morals by agreement: Oxford University Press, UK.

Gillet, J., Cartwright, E., \& Van Vugt, M. (2011). Selfish or servant leadership? Evolutionary predictions on leadership personalities in coordination games. Personality and Individual Differences, 51(3), 231-236.

Gilligan, M. J., Pasquale, B. J., \& Samii, C. (2014). Civil War and Social Cohesion: Lab in the Field Evidence from Nepal. American Journal of Political Science, 58(3), 604-619.

Glaeser, E. L., Laibson, D., \& Sacerdote, B. (2002). An economic approach to social capital*. The Economic Journal, 112(483), F437-F458.

Goeree, J. K., \& Holt, C. A. (2005). An experimental study of costly coordination. Games and Economic Behavior, 51(2), 349-364.

Gould, R. V. (1993). Collective Action and Network Structure. American Sociological Review, 58(2), 182-196.

Goyal, S., \& Vega-Redondo, F. (2005). Network formation and social coordination. Games and Economic Behavior, 50(2), 178-207.

Grossman, S. J., \& Hart, O. D. (1980). Takeover Bids, The Free-Rider Problem, and the Theory of the Corporation. The Bell Journal of Economics, 11(1), 42-64, doi:10.2307/3003400.

Hardin, R. (1982). Collective action. Baltimore: Johns Hopkins University Press.

Harrison, G. W., \& List, J. A. (2004). Field Experiments. Journal of Economic Literature, 42(4), 10091055, doi:doi: 10.1257/0022051043004577.

Harsanyi, J. C., \& Selten, R. (1988). A general theory of equilibrium selection in games (Vol. 1, MIT Press Books).

Hirshleifer, J. (1983). From weakest-link to best-shot: The voluntary provision of public goods. Public choice, 41(3), 371-386.

Hoff, K. Beyond Rosenstein-Rodan: the modern theory of coordination problems in development. In Proceedings of the Annual World Bank Conference on Development Economics, 2000 (pp. 145188) 
Hoff, K., \& Stiglitz, J. (2001). Modern economic theory and development. In G. M. Meier, \& J. E. Stiglitz (Eds.), Frontiers of development economics: The future in perspective. New York: Oxford University Press.

Holt, C. A. (2007). Markets, games, and strategic behavior: recipes for interactive learning: Pearson Addison Wesley.

Horwitz, A. V. (1990). The logic of social control: Springer Science \& Business Media.

Jack, B. K., \& Recalde, M. P. (2015). Leadership and the voluntary provision of public goods: Field evidence from Bolivia. Journal of Public Economics, 122, 80-93.

Jackson, M. O. (2008). Social and Economic Networks. Princeton: Princeton University Press.

Jackson, M. O. (2010). An overview of social networks and economic applications. The handbook of social economics, 1, 511-585.

Jackson, M. O., Rodriguez-Barraquer, T., \& Tan, X. (2012). Social Capital and Social Quilts: Network Patterns of Favor Exchange. American Economic Review, 102(5), 1857-1897, doi:doi: 10.1257/aer.102.5.1857.

Jackson, M. O., \& Watts, A. (2002). On the formation of interaction networks in social coordination games. Games and Economic Behavior, 41(2), 265-291.

Jeske, D., \& Fumerton, R. (2011). Readings in Political Philosophy: Theory and Applications: Broadview Press.

Kandori, M., Mailath, G. J., \& Rob, R. (1993). Learning, Mutation, and Long Run Equilibria in Games. Econometrica, 61(1), 29-56, doi:10.2307/2951777.

Karlan, D. S. (2005). Using Experimental Economics to Measure Social Capital and Predict Financial Decisions. American Economic Review, 95(5), 1688-1699, doi:doi: $10.1257 / 000282805775014407$.

Kawachi, I., Subramanian, S. V., \& Kim, D. (2008). Social capital and health: Springer.

Keser, C., Ehrhart, K.-M., \& Berninghaus, S. K. (1998). Coordination and local interaction: experimental evidence. Economics Letters, 58(3), 269-275.

Knez, M., \& Camerer, C. (2000). Increasing cooperation in prisoner's dilemmas by establishing a precedent of efficiency in coordination games. Organizational Behavior and Human Decision Processes, 82(2), 194-216.

Kosfeld, M., \& Rustagi, D. (2015). Leader Punishment and Cooperation in Groups: Experimental Field Evidence from Commons Management in Ethiopia. The American Economic Review, 105(2), 747-783.

Krupka, E. L., \& Weber, R. A. (2013). Identifying social norms using coordination games: Why does dictator game sharing vary? Journal of the European Economic Association, 11(3), 495-524.

Kuang, X. J., Weber, R. A., \& Dana, J. (2007). How effective is advice from interested parties?: An experimental test using a pure coordination game. Journal of Economic Behavior \& Organization, 62(4), 591-604.

Latham, G. P., \& Saari, L. M. (1979). Importance of supportive relationships in goal setting. Journal of Applied Psychology, 64(2), 151.

Latorre López, M. C. (2004). About the positive relationship between social capital and urban violence: a theoretical and empirical analysis [Sobre la relación positiva entre el capital social y la violencia urbana: un análisis teórico y empírico]. In U. d. L. Andes (Ed.), Documentos CEDE. Bogota D.C.

Lewis, D. (1969). Convention. Cambridge Mass.: Harvard University Press.

List, J. A., \& Rasul, I. (2011). Field experiments in labor economics. Handbook of labor economics, 4, 103-228.

Mackie, G., Moneti, F., Denny, E., \& Shakya, H. (2015). What are social norms? How are they measured? Working papers: UNICEF/UCSD Center on Global Justice Project Cooperation Agreement. .

Matsuyama, K. (1997). Economic development as coordination problems: Clarendon Press: Oxford.

McAdams, R. H. (1997). The origin, development, and regulation of norms. Michigan Law Review, 338433. 
McAdams, R. H. (2008). Beyond the Prisoners' Dilemma: Coordination, Game Theory, and Law. S. Cal. L. Rev., 82, 209.

McLeish, K. N., \& Oxoby, R. J. (2011). Social interactions and the salience of social identity. Journal of Economic Psychology, 32(1), 172-178, doi:http://dx.doi.org/10.1016/j.joep.2010.11.003.

MESEP (2012). Monetary poverty in Colombia: New methodology and figures 2002-2010 [Pobreza monetaria en Colombia: Nueva metodología y cifras 2002-2010]. In DNP, \& DANE (Eds.). Bogota, Colombia.

Narayan, D., \& Cassidy, M. F. (2001). A dimensional approach to measuring social capital: development and validation of a social capital inventory. Current sociology, 49(2), 59-102.

Ñopo, H., Calonico, S., Candelo, N., Cardenas, J. C., Chong, A., \& Polania-Reyes, S. (2008). To what extent do latin americans trust and cooperate? Field experiments on social exclusion in six Latin American countries (IPES 2008: Outsiders? The Changing Patterns of Exclusion in Latin America and the Caribbean): IADB IPES 2008 Report.

Nupia, O. (2011). Anti-poverty programs and Presidential election outcomes: Familias en Accion in Colombia. Documento CEDE(2012).

Olson, M. (2009). The logic of collective action (Vol. 124): Harvard University Press.

Opp, K.-D. (1989). The Rationality of Political Protests: A Comparative Analysis of Rational Choice Theory. West-view: Boulder.

Ostrom, E. (1998). A behavioral approach to the rational choice theory of collective action: Presidential address, American Political Science Association, 1997. American political science review, 92(01), 1-22.

Parkhurst, G. M., Shogren, J. F., \& Bastian, C. (2004). Repetition, communication, and coordination failure. Experimental Economics, 7(2), 141-152.

Polania-Reyes, S. (2005). Capital social e ingreso de los hogares del sector urbano en Colombia. REVISTA DESARROLLO Y SOCIEDAD, 51.

Polania-Reyes, S. (2016). Leading by non-example: do leader's social preferences matter for cooperation? Experimental evidence from Colombia. .

Portes, A., \& Landolt, P. (2000). Social capital: promise and pitfalls of its role in development. Journal of Latin American Studies, 32(02), 529-547.

Posner, E. A. (2002). Law and social norms: Harvard University Press.

Putnam, R. (1995). Bowling alone: America's declining social capital. Journal of democracy, 6(1), 65-78.

Putnam, R. (2001a). Bowling alone: The collapse and revival of American community: Simon and Schuster.

Putnam, R. (2001b). Social capital: Measurement and consequences. Canadian Journal of Policy Research, 2(1), 41-51.

Putnam, R., Leonardi, R., \& Nanetti, R. Y. (1993). Making democracy work: Civic traditions in modern Italy: Princeton University Press.

Rhodes, C. M., \& Wilson, R. K. (2008). The Problem of Common Choice in Symmetric N-person Coordination Games. Handbook of Experimental Economics Results, 1, 463-471.

Richerson, P. J., \& Boyd, R. (2008). Not by genes alone: How culture transformed human evolution: University of Chicago Press.

Rousseau, J.-J. (2000). Discourse on the Origin of Inequality: Oxford University Press.

Rustagi, D., Engel, S., \& Kosfeld, M. (2010). Conditional cooperation and costly monitoring explain success in forest commons management. science, 330(6006), 961-965.

Samuelson, P. A. (1954). The pure theory of public expenditure. The review of economics and statistics, 387-389.

Schelling, T. C. (1960). The strategy of conflict: Harvard University Press.

Schmidt, D., Shupp, R., Walker, J. M., \& Ostrom, E. (2003). Playing safe in coordination games:: the roles of risk dominance, payoff dominance, and history of play. Games and Economic Behavior, 42(2), 281-299. 
Stoddard, O., \& Leibbrandt, A. (2014). An experimental study on the relevance and scope of nationality as a coordination device. Economic Inquiry, 52(4), 1392-1407.

Sugden, R. (1995). A Theory of Focal Points. The Economic Journal, 105(430), 533-550, doi: $10.2307 / 2235016$.

Sugden, R. (2000). The Motivating Power of Expectations. In J. Nida-Rümelin, \& W. Spohn (Eds.), Rationality, Rules, and Structure (Vol. 28, pp. 103-129, Theory and Decision Library): Springer Netherlands.

Sugden, R. (2003). The logic of team reasoning. Philosophical explorations, 6(3), 165-181.

Tajfel, H. (1982). Social psychology of intergroup relations. Annual review of psychology, 33(1), 1-39.

Thoni, C., Tyran, J.-R., \& Wengstrom, E. (2012). Microfoundations of social capital. Journal of Public Economics, 96(7), 635-643.

Uphoff, N. (2001). Understanding social capital: learning from the analysis and experience of participation. In P. Dasgupta, \& I. Serageldin (Eds.), Social capital: A multifaceted perspective (pp. 215-249): World Bank Publications.

Van Huyck, J. B., Battalio, R. C., \& Beil, R. O. (1990). Tacit Coordination Games, Strategic Uncertainty, and Coordination Failure. The American Economic Review, 80(1), 234-248.

Van Huyck, J. B., Battalio, R. C., \& Beil, R. O. (1991). Strategic Uncertainty, Equilibrium Selection, and Coordination Failure in Average Opinion Games. The Quarterly Journal of Economics, 106(3), 885-910.

Van Huyck, J. B., Battalio, R. C., \& Rankin, F. W. (1997). ON THE ORIGIN OF CONVENTION: EVIDENCE FROM COORDINATION GAMES*. The Economic Journal, 107(442), 576-596.

Van Huyck, J. B., Battalio, R. C., \& Rankin, F. W. (2007). Evidence on learning in coordination games. Experimental Economics, 10(3), 205-220.

Voors, M., Bulte, E., Kontoleon, A., List, J. A., \& Turley, T. (2011). Using Artefactual Field Experiments to Learn about the Incentives for Sustainable Forest Use in Developing Economies. American Economic Review, 101(3), 329-333, doi:doi: 10.1257/aer.101.3.329.

Voors, M., Turley, T., Kontoleon, A., Bulte, E., \& List, J. A. (2012). Exploring whether behavior in context-free experiments is predictive of behavior in the field: Evidence from lab and field experiments in rural Sierra Leone. Economics Letters, 114(3), 308-311.

Warren, M. R. (1998). Community Building and Political Power A Community Organizing Approach to Democratic Renewal. American Behavioral Scientist, 42(1), 78-92.

Weber, R. A. (2006). Managing Growth to Achieve Efficient Coordination in Large Groups. American Economic Review, 96(1), 114-126, doi:doi: 10.1257/000282806776157588.

Williams, R. (2006). Generalized ordered logit/partial proportional odds models for ordinal dependent variables. Stata Journal, 6(1), 58-82.

Woolcock, M. (1998). Social capital and economic development: Toward a theoretical synthesis and policy framework. Theory and society, 27(2), 151-208.

Woolcock, M., \& Narayan, D. (2000). Social capital: Implications for development theory, research, and policy. The world bank research observer, 15(2), 225-249.

Young, H. P. (1993). The Evolution of Conventions. Econometrica, 61(1), 57-84, doi:10.2307/2951778.

Young, H. P. (2008). Social Norms. In S. N. Durlauf, \& L. E. Blume (Eds.), The New Palgrave Dictionary of Economics: Palgrave Macmillan.

Zárate, R. A., Conover, E., Camacho, A., \& Baez, J. E. (2013). Conditional Cash Transfers, Political Participation, and Voting Behavior. 


\section{Appendices}

\section{i. $\quad$ The Conditional Cash Transfer program: Familias en Acción and Cartagena}

Cartagena is the fifth largest city in Colombia, with 993 thousand inhabitants in 2008. It is the third poorest city in the country, with $40.2 \%$ poor and $6.9 \%$ in extreme poverty in 2008 (MESEP 2012). Ciénaga and Pozón belong to the poorest locality (i.e. the lowest level of income, the lowest education coverage, the highest infant mortality rates and the worst living conditions in Cartagena. In 2009, Pozón is recognized as the densest neighborhood with an area of $273 \mathrm{Ha}$ and 45 thousand inhabitants while Ciénaga has $463 \mathrm{Ha}$ and 102 thousand inhabitants (see Figure A1). By 2006, Pozón and Ciénaga are considered by the local authorities as very similar, with a percentage of households with lower income $(56 \%)$ and the same average time in school (6 years) ${ }^{59}$.

In January 2005, the FA authorities decided to pilot the program in Pozón with 5 thousand Sisben 1 households. A new enrolment wave took place in March 2006 for 2.5 thousand displaced households (i.e. households that were forced to leave their home because of the civil conflict). After that, displaced households have been allowed to enroll in the program at any time. Between 2005 and the first half of 2007, the program operated in Pozón but had not been implemented in other neighborhoods, despite there being other two neighborhoods (Nelson Mandela and Ciénaga de la Virgen) identified by the FA authorities as eligible to participate in the pilot. In late August 2007, a new wave of massive enrolment to the program started in every municipality in the country, regardless of its population. The program was also rolled out in all the poorest neighborhoods of Cartagena, including Ciénaga. In total 35.5 thousand households were enrolled in Cartagena, including new households from Pozón. In our data set 58 of 404 individuals who attended the follow-up (14.4\% of Pozón sample) were enrolled in the program in 2007. The following enrollment waves after 2007 (for non-displaced households) took place in 2009 (32.000 households), in 2012 (22,000 households) and 2013 (7,000 households). Regarding the payment procedure of FA, the first payment in Pozón was in March 2005 followed by a bi-monthly payment. In 2007, the first payment in Ciénaga was in October 2007.

From January 2005, ECs were held quarterly in Pozón. However, a ML was allowed to organize EC with her beneficiaries whenever she considered. The number of ECs was determined by how proactivity the ML was. There were differences in the EC in Pozón between the period 2005 to 2007 and from 2007 to 2008. As the ML were trained, they felt empowered within their community, displacing other community leaders.

Although the national office does not make attendance to the assemblies a mandatory requirement, from 2005 to 2010 the local office made it so. The percentage of the neighborhood population receiving the program was 79\% in Pozón in 2006 and 22.4\% in all of Cartagena in 2008.

\section{ii. $\quad$ The Voluntary Contribution Mechanism ${ }^{60}$ (See Attanasio et al. 2015)}

In our game, each player receives an endowment of one token to be invested either in a private or a group account. The decision is made privately and simultaneously. The earnings are calculated in the following way: if the player chooses to invest in the private account, the token is converted into $\$ 5$ and will be given entirely to her. In addition each player receives, regardless of how she has invested her own her token, $\$ 0.40$ for each token invested in the group account by any other member in the group of 25 players. Therefore, her total earnings at the end of this round are $(\$ 5)+(\$ 0.40 \times$ Sum of Tokens invested by the group). If the player chooses to invest her token in the group account, she will receive 0.4 for each token

\footnotetext{
${ }^{59}$ For more resources see Attanasio et al.(2015).

${ }^{60}$ The experimental design of the VCM described here was developed by Juan Camilo Cárdenas, Maria Claudia Lopez, Natalia Candelo and this author.
} 
invested in the group account by her and in the rest of the group. In this case her total earnings at the end of the round will be $(\$ 0)+(\$ 0.40 \mathrm{x}$ Sum of Tokens invested by the group). Each player makes her private decision by selecting a card which says if she is going to invest her money in the group account or to keep it for herself (i.e. private account). The experimenter then collects the "decisions cards," totals them up, multiplies by $\$ 0.40$ the amount and credits the relevant amounts to each player. The relevant amounts, however, are only revealed and paid at the end of the session and after a second round of the same game $^{61}$.

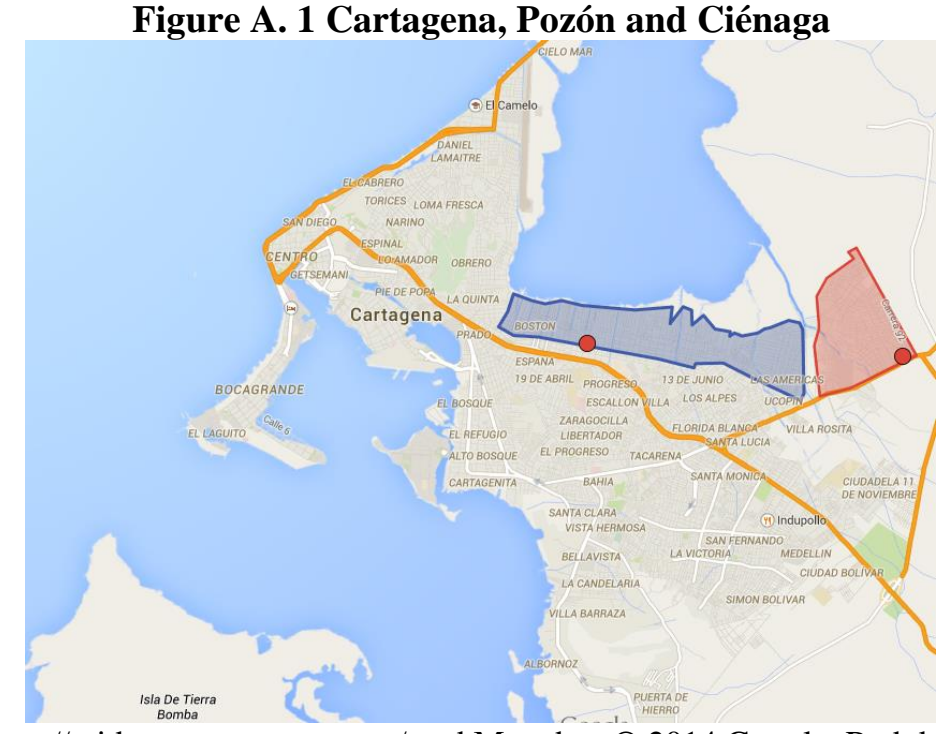

Source: http://midas.cartagena.gov.co/ and Map data @ 2014 Google. Red dots are where the sessions were held. The red area is Pozón and the blue one Ciénaga.

\section{iii. $\quad$ Relation between the CCT and traditional social capital measures}

In this section we report the relation between traditional social capital measures collected in the survey and exposure to the CCT, experimental measures and individual network information. We use different sets of controls. Among the socio-economic characteristics we include especially those characteristics we found to show differences between the short exposure and long exposure samples.

In Table A3a. we show the effect of exposure to the program (1 if the player has been in the program for more than a year in dichotomous social capital measures). All of them are dummy survey measures and we report the marginal effect of exposure in a probit regression model for each social capital variable.

All social capital measures are positively related to being enrolled in the program for more than a year. In particular, we find a positive and significant relation between exposure to the program and membership in organizations, participation in bonding and bridging associations, voting in the presidential elections and attendance to the FA meetings, as well as network information such as the connectivity score assigned to

\footnotetext{
${ }^{61}$ The marginal per capita return (MPCR) of this game is one of the lowest in the literature. The goal was to mimic a measure of what would be called bridging social capital, the ability to overcome social dilemmas in a very large group. Instead, we argue it matches more closely the reality we are trying to depict. Given the level of deprivation in the neighborhoods we study, the intensity of the social dilemma is arguably much higher than in most other lab, or even lab-in-the-field, studies, and a low MPCR is better fitted than a higher one. In addition, the low MPCR makes our results more forceful. Because the power of our analysis would have been maximized if we had had a MPCR of $50 \%$, a low value provides evidence that if the coefficient is subject to any bias it will be downward bias. Since we claim to provide a social capital measure, where social dilemmas are key -and hence a low MPCR appropriate-, the low MPCR provides an additional source of validity to the measure.
} 
each player, the percentage of participants who considered the player as a leader and the percentage of these informal leaders in the session. Among associations, there is a positive relation with religious participation and exposure to the program. This analysis is supported by Table A1 in this appendix.

Finally, we also report the analysis for the number of connections, friends, relatives and acquaintances the player identifies in the session. We report the marginal effect of exposure of a linear regression model for each social capital variable.

In Table A3b, we show the effect of experimental measures in continuous Social capital measures. We report the marginal effect of exposure of a linear regression model for each social capital continuous variable. All experimental measures are positively related with network information such as the connectivity score assigned to each player, the percentage of participants who considered the player as a leader and the percentage of these informal leaders in the session. Finally, we also report the analysis for the number of connections, friends, relatives and acquaintances the player identifies in the session.

\section{iv. Relation between the CCT and behavior in the cooperation game}

In Table 4 and 5 we report the results for the regression analysis of willingness to cooperate in round 1 and round 2. In both cooperation decisions, the presence of at list one ML in the session increases the likelihood to cooperate by $17 \%$. This result is robust to different specifications and highlights the importance of leaders in collective action (Jones and Olken 2005, Kosfeld and Rustagi 2015).

We also observe that being a ML decreases the individual willingness to cooperate in the first round by $12 \%$. This result is consistent with previous studies on spitefulness (Fehr, Hoff, and Kshetramade 2008, Kosfeld and Rustagi 2015) and the role of status on cooperation (Brooks, Hoff and Pandey 2014). Spiteful preferences -the desire to reduce another's material payoff for the mere purpose of increasing one's relative payoff- (Fehr et al. 2008) and in social psychology, by sacrificing total surplus and equality for the sake of a larger payoff difference between "self" and "other." (Van Lange 2009). Fehr et al. (2008) suggest that the willingness to reduce another's material payoff is stronger among individuals belonging to high caste status in India.

\section{v. $\quad$ Capturing beliefs: a Quantal Response Non-Equilibrium approach}

One of our main points is that the tradeoff between risk dominance and payoff dominance is directly linked to beliefs materializing as a social norm. In order to estimate the probabilities of choosing the most efficient effort level we estimate a Quantal Response Equilibrium (QRE) model (McKelvey and Palfrey, $1995,1998)^{62}$.

In a symmetric QRE, each player uses a mixed strategy, $p$, which itself induces a distribution $p_{\text {min }}$ over the minimum effort of all opponents. The expected payoff from choosing $e_{i} \in\{1,2,3\}$ is thus given by

$$
E\left[\pi\left(e_{i}, p_{\min }\right)\right]=3 \sum_{k=1}^{3} p_{\min }(k)\left(1+\min \left(k, e_{i}\right)-\frac{2}{3} e_{i}\right) .
$$

The QRE condition relates the probability of playing a given strategy to the relative advantage of the expected payoff. Using the conventional logit specification, the logit equilibrium is characterized by the following

\footnotetext{
${ }^{62}$ The QRE model allows agents to make mistakes and assumes that agents take into account the possibility that others are making mistakes when drawing inferences from their actions. Since the ME game has three equally possible equilibria, we use this approach due to the different predictions it offers.
} 


$$
p\left(e_{i}=j\right)=\frac{e^{\lambda E\left[\pi\left(j, p_{\min }\right)\right]}}{\sum_{k=1}^{3} e^{\lambda E\left[\pi\left(k, p_{\min }\right)\right]}}
$$

where $\lambda \in[0, \infty)$ captures the degree of payoff-maximizing behavior (a higher value of $\lambda$ meaning more payoff responsiveness - less noise, and with $\lambda=0$ the density function becomes uniform over its support and behavior becomes random).

Although we cannot give a closed-form solution for the QRE (due to the large number of players, see Anderson et al., 2001) we provide a numerical solution using a grid search. The QRE can be defined as the global minimum (of all $p=\left(p_{1}, p_{2}, p_{3}\right) \in[0,1]^{3}$ ) of the mean squared error function,

$$
\left\|p(j)-\frac{e^{\lambda E\left[\pi\left(j, p_{\text {min }}\right)\right]}}{\sum_{k=1}^{3} e^{\lambda E\left[\pi\left(k, p_{\text {min }}\right)\right]}}\right\|_{2} .
$$

Figure A2 presents the QRE along the dimension of $p_{3}$ as a function of $\lambda$. Despite that the limit point of the $\mathrm{QRE}$ as $\lambda \rightarrow \infty$ is the risk-dominant equilibrium $p=(1,0,0)$, given that the cost is greater than $1 / 8$, ee observe that there might be multiple equilibria in our model. With this in mind we will abstract from the global equilibrium, which is not particularly helpful for our purposes. Instead we will consider local minima of (5), and more importantly how they depend on initial conditions $\left(p^{0}\right)$ of the maximization routine. Pseudo-equilibria are defined as local minima of the mean squared error function in (6). Different initial conditions (beliefs, i.e. values of $p^{0}$ ) lead to different minimization regions, and hence different pseudo-equilibria. Initial conditions matter for a highly non-monotonic objective function, as the algorithm is easily stuck at a local optimum. We argue that this is an adequate proxy for the formation of beliefs and hence of the social norm ${ }^{63}$. Though the QRE path might converge to the risk-dominant equilibrium, we want to understand under what initial conditions a high value of $p_{3}$ (the outcome probability of choosing the highest level of effort) is sustained in local equilibria.

We want to compare the effect of different initial conditions on the outcome, $p_{3}$. Figure A3 shows that a high value of $p_{3}$ can be obtained for a very high initial condition $p_{3}^{064}$. Instead for a wide interval of initial conditions (i.e. $p_{3} \leq 95 \%$ ) the trend of the pseudo-QRE converges to that of the QRE, which is depicted in Figure A2. This is in line with our thesis that reaching the Pareto dominant equilibrium is a matter of social norms, which are captured by initial beliefs about other players' actions. If others are perceived to be very likely to play the Pareto dominant equilibrium such equilibrium is sustained.

One concern of depending on the initial conditions of the system is the stability of the result. In order to understand this potential issue more carefully we look at various slices in our grid search, which we present in Figure 3: as the initial condition $\left(\boldsymbol{p}_{\mathbf{3}}^{\mathbf{0}}\right)$ increases, there is a transition from a trend towards 1 to fluctuation in the outcome value $\boldsymbol{p}_{3}$, after which a (more stable) different trend is achieved which stays at high values of $\boldsymbol{p}_{3}$.

The QRE approach in section two enables us to evaluate the degree to which the theory explains behavior in the field. ${ }^{65}$ An interesting discussion is that of the determinants of the rationality parameter that

\footnotetext{
${ }^{63}$ This approach is consistent with the assumption by Mailath (1998) and de Paula (2013) on the equilibrium selection mechanism for the econometric analysis of incomplete-information games with possibly many equilibria. "If an equilibrium is established as a mode of behavior by past play, custom, or culture, this equilibrium becomes a focal point for those involved. When observed games are drawn from a population that is culturally or geographically close, sharing similar norms and conventions, one would expect this assumption to be adequate." (de Paula, 2013:120)

${ }^{64} p_{1}^{0}$ and $p_{2}^{0}$ are estimated optimally using a grid search.

${ }^{65}$ This approach is also used by Chen and Chen (2011) with a model of identity. They show that a salient group identity increases coordination on the Pareto superior outcome in the lab for a $2 \times 2 \mathrm{ME}$ game.
} 
optimizes the solution to (5). Having estimated the pseudo-QRE that corresponds to each initial condition, we interact this initial condition with different attributes of the individual, in particular the level of exposure to the CCT program.

\section{Figure A2 Quantal Response Equilibrium $p_{3}$} as a function of $\lambda$

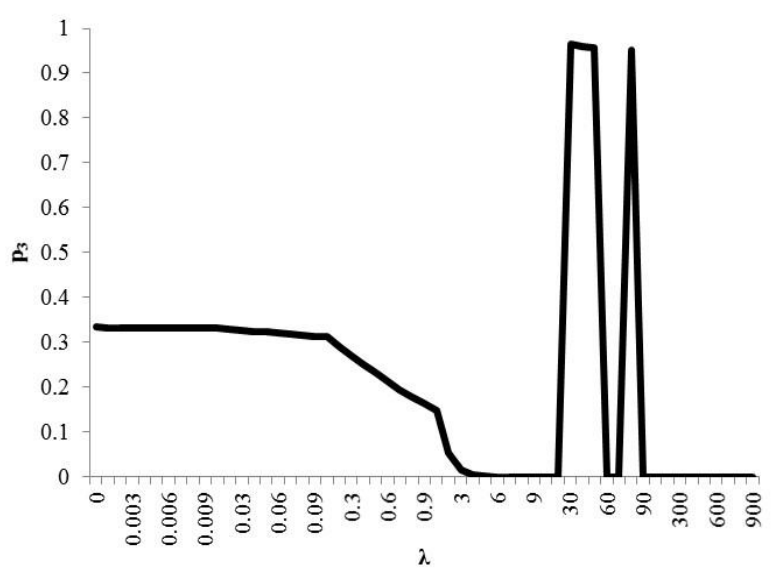

Figure A3. Pseudo-Quantal Response Equilibrium $p_{3}$ as a function of $\lambda$

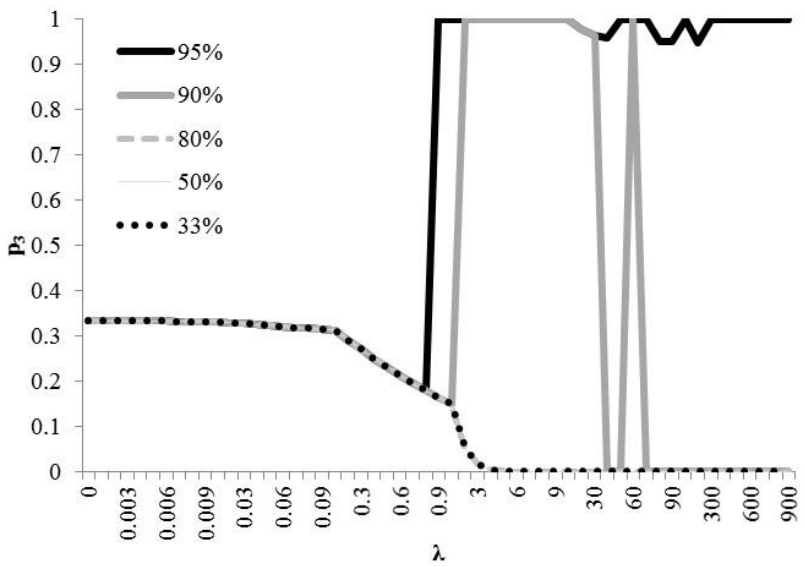

Note: Different series correspond to different values for $p_{3}^{0}$

Figure A4. Pseudo-QRE for initial values of $p_{3}$ close to $90 \%$

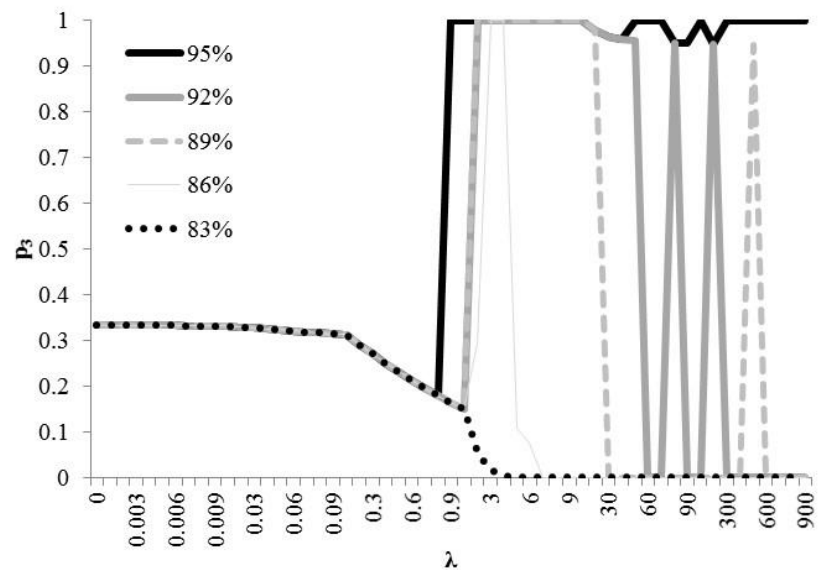

Note: Different series correspond to different values for $p_{3}^{0}$

The first one we want to understand is the effect of exposure to the CCT program. To do so we compute the pseudo-QRE separately for the subsample with short exposure to the program from that with long exposure to it. We calibrate $\lambda$ with the objective of minimizing the mean squared error (MSE) between the distribution of efforts observed within the sample and the one predicted from the pseudo-QRE using $\lambda$. Figure A5 presents the MSE as a function of $\lambda$ for the two subsamples and the whole sample of beneficiaries of the CCT. In Table A.6 in the appendix we present the calibrated $\lambda$ for the two possible scenarios (low beliefs and high beliefs as initial conditions) and whether the long exposure and short exposure samples. From Figure 1 we find that having high beliefs on others choosing the highest level of effort is not enough if there isn't a $\lambda>0.6$ in order to obtain convergence to the Pareto-dominant equilibrium. Figure A and Table A.6 show that only the long exposure group had such $\lambda$.

Figure A6 compares two pseudo-equilibria: the one implied by a high initial belief (an initial condition of $p_{3}, p_{3}^{0}=95 \%$ ) and the one implied by a low initial belief (an initial condition of $p_{3}, p_{3}^{0}=33.33 \%$ ). In 
Figure A6 below we plot the model outcome for each of the two subsamples. In the panel b of Figure A6. we observe that the predicted equilibrium for individuals with long exposure is similar to the observed data. For those beneficiaries with short exposure, the actual data is very similar to the theoretical prediction. As seen in the previous section, the program effect on coordination is notable, which is captured by the difference in observed distributions across the two figures. Again, low initial conditions cannot generate a prediction that accurately matches the real distribution: high initial conditions are needed to do so.

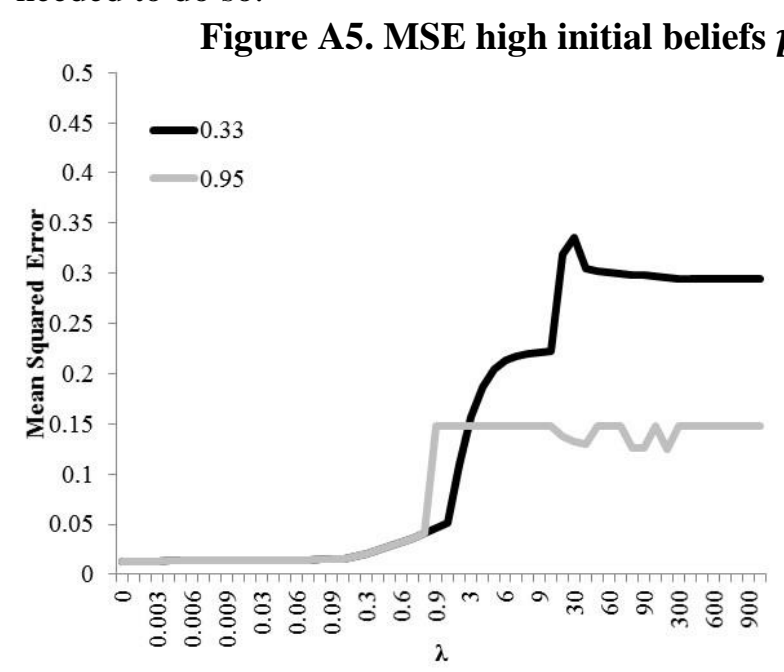

a. Short exposure to the CCT subsample

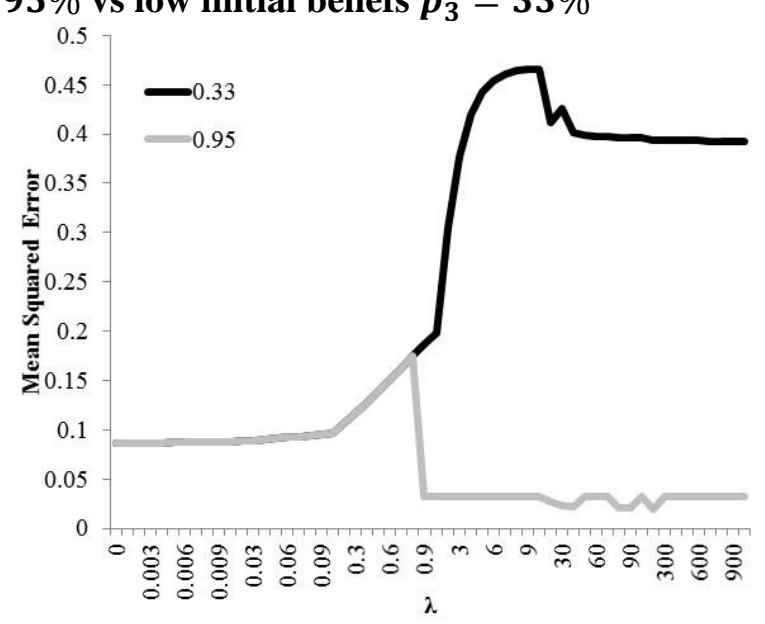

b. Long exposure to the CCT subsample

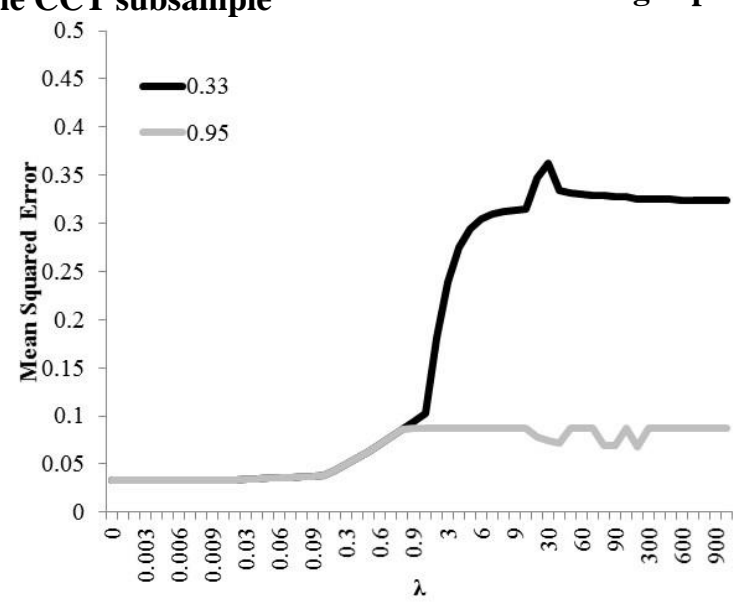

c. Whole sample

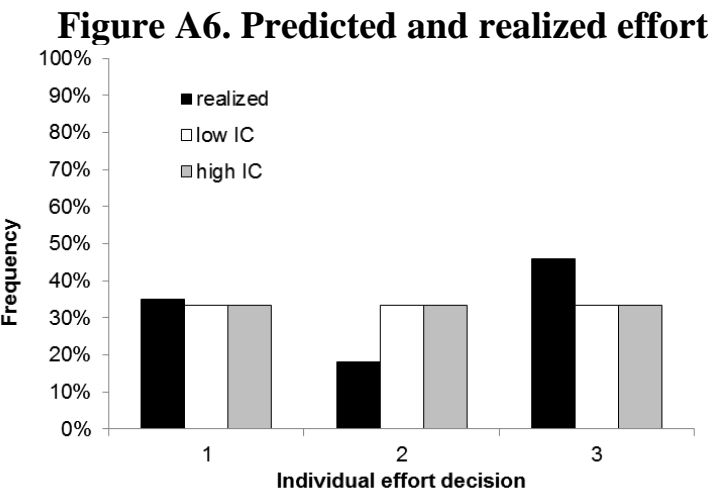

a. Short exposure to the program subsample

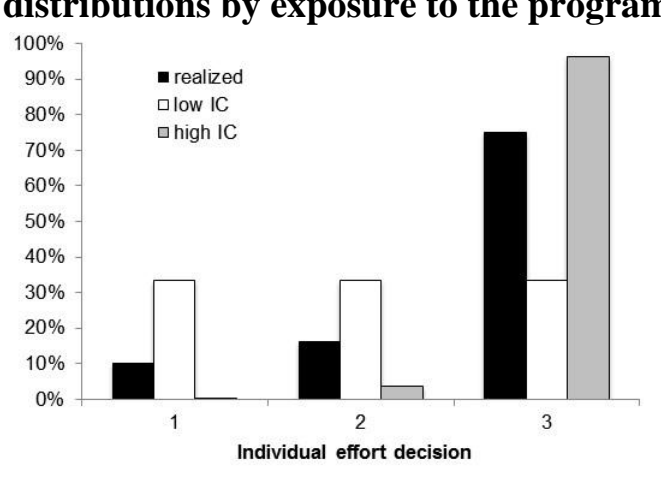

b. Long exposure to the program subsample 
Panels in Figure A7 show the comparison between predicted and realized effort distributions by attributes that were considered as potential drivers for $\lambda$ : level of education, age, household head, household size, and age. None of these attribute turned out to introduce a meaningful distinction in the formation of beliefs: the only one is the length of exposure ${ }^{66}$.

Figure A7 Predicted and realized effort distributions by individual attributes

A.7.1 Level of education attained

a. Less than Secondary completed

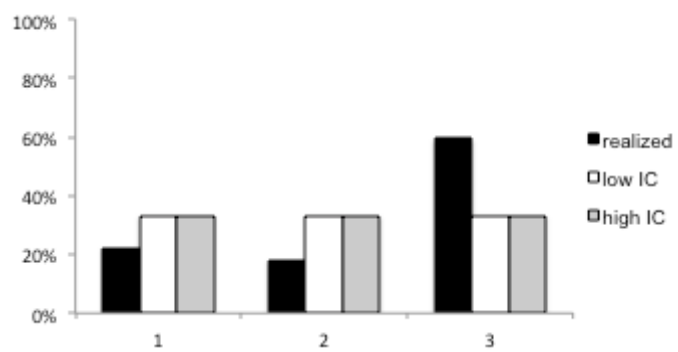

A.7.2.Age

a. Population younger than 35

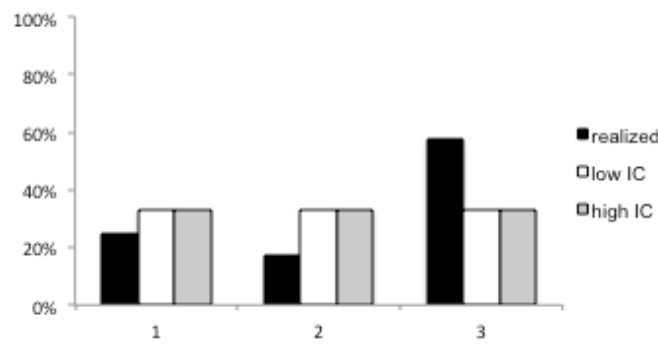

A.7.3.Status in household

a. Head of household

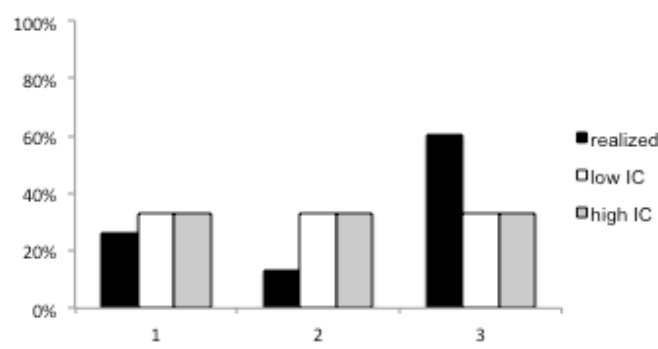

A.7.4. Number of people in the household

a. Less than or equal to five people

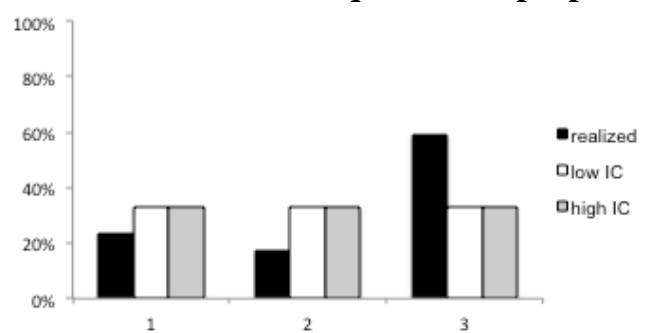

b. Secondary complete or higher

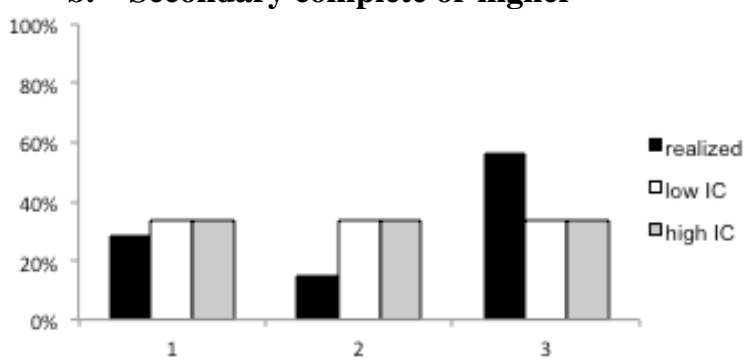

b. Population older than 35

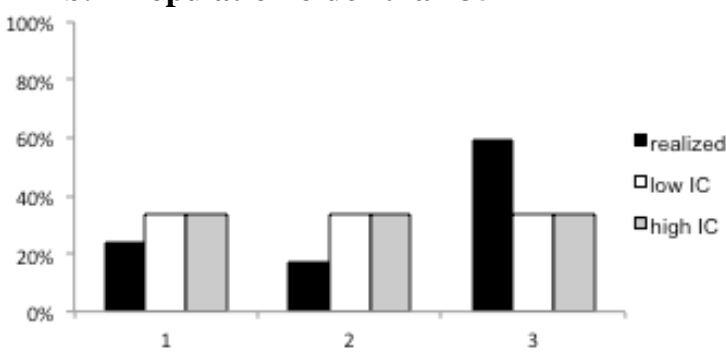

b. Non-head of household

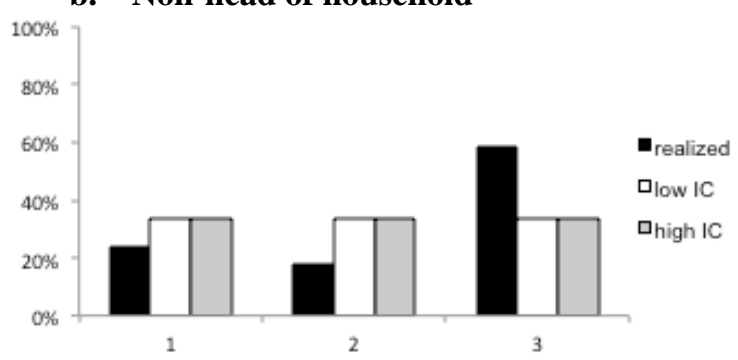

b. More than five people

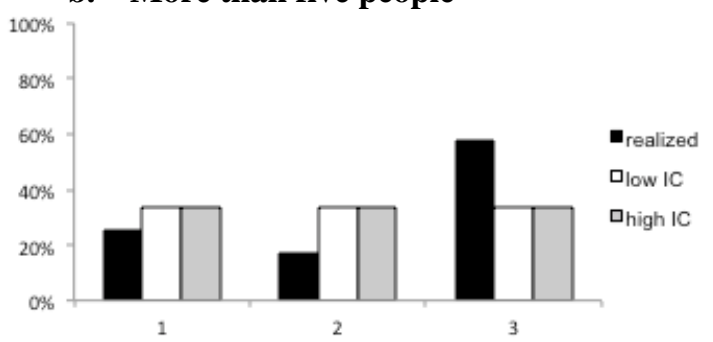

${ }^{66} \mathrm{We}$ also considered whether the individual membership in organizations and whether the individual is a leader. 


\section{vi. $\quad$ Complementary Tables}

Table A. 1 Spearman correlation coefficients experimental with survey measures

\begin{tabular}{|c|c|c|c|c|}
\hline \multirow{2}{*}{\multicolumn{2}{|c|}{ Survey Social Capital measures }} & \multirow{2}{*}{$\begin{array}{c}\text { Level of } \\
\text { effort }\end{array}$} & \multicolumn{2}{|c|}{ Cooperation } \\
\hline & & & Round 1 & Round 2 \\
\hline \multicolumn{2}{|c|}{ Participation in neighborhood decisions } & 0.05 & -0.02 & 0.04 \\
\hline \multicolumn{2}{|c|}{ Participation in the neighborhood meetings } & 0.03 & -0.04 & 0.03 \\
\hline \multicolumn{2}{|c|}{ Membership in at least one organization } & 0.04 & 0.01 & $0.07 *$ \\
\hline \multicolumn{2}{|c|}{ Bonding Social capital } & 0.02 & 0.00 & $0.06 *$ \\
\hline \multicolumn{2}{|c|}{ Bridging Social capital } & 0.06 & 0.00 & $0.07 *$ \\
\hline \multicolumn{2}{|c|}{ Linking Social capital } & 0.01 & -0.02 & 0.00 \\
\hline \multicolumn{2}{|c|}{ Membership in a charity } & 0.00 & 0.02 & $0.09 * *$ \\
\hline \multicolumn{2}{|c|}{ Membership in a volunteer work association } & 0.05 & -0.02 & 0.03 \\
\hline \multicolumn{2}{|c|}{ Membership in a religious association } & 0.01 & -0.01 & 0.02 \\
\hline \multicolumn{2}{|c|}{ Membership in a cultural or sports association } & $-0.06^{*}$ & -0.06 & -0.03 \\
\hline \multicolumn{2}{|c|}{ Membership in a education association } & 0.06 & 0.03 & $0.09 * *$ \\
\hline \multicolumn{2}{|c|}{ Membership in an environmental association } & $0.08 * *$ & -0.04 & 0.04 \\
\hline \multicolumn{2}{|c|}{ Membership in a security association } & 0.03 & -0.02 & -0.02 \\
\hline \multicolumn{2}{|c|}{ Membership in a union, labor association } & 0.04 & -0.03 & -0.03 \\
\hline \multicolumn{2}{|c|}{ Membership in a political party } & 0.04 & -0.03 & -0.03 \\
\hline \multicolumn{2}{|c|}{ Voted in local elections (2007) } & 0.00 & 0.00 & 0.03 \\
\hline \multicolumn{2}{|c|}{ Voted in presidential elections (2006) } & 0.01 & -0.01 & 0.02 \\
\hline \multirow{3}{*}{$\begin{array}{l}\text { Trust: do you } \\
\text { consider that you } \\
\text { can trust in? }\end{array}$} & Most people & 0.04 & -0.03 & -0.03 \\
\hline & Few people & 0.04 & 0.02 & -0.06 \\
\hline & None & -0.06 & 0.00 & $0.07 * *$ \\
\hline \multirow{3}{*}{$\begin{array}{l}\text { Perception within } \\
\text { the community }\end{array}$} & Cooperation & -0.02 & -0.02 & -0.02 \\
\hline & Reciprocity & 0.05 & 0.00 & 0.00 \\
\hline & Self-regarding & -0.01 & 0.02 & 0.02 \\
\hline \multirow{5}{*}{$\begin{array}{l}\text { Always or } \\
\text { usually, has } \\
\text { she helped } \\
\text { anyone }\end{array}$} & h money & $0.07 *$ & 0.04 & 0.02 \\
\hline & offering her seat in the bus & 0.01 & -0.03 & $0.13 * * *$ \\
\hline & neone with domestic work & 0.04 & 0.01 & $0.09 * *$ \\
\hline & carrying a case, package, groceries & $0.10 * * *$ & 0.02 & $0.09 * *$ \\
\hline & taking care of the house or children & $0.07 * *$ & 0.03 & 0.06 \\
\hline
\end{tabular}

Bonding social capital is defined as membership in Charity and /or religious associations. Bridging social capital is defined as membership in Volunteer work, ethnic, cultural, sports, and environmental associations. Linking social capital is defined as membership in Community action, education (parents' network), security associations, union, political parties. * Significant at $10 \%$; ** significant at $5 \%$; *** significant at $1 \%$.

Table A. 2 Spearman correlation coefficients experimental measures with network information

\begin{tabular}{|c|c|c|c|c|}
\hline \multirow{2}{*}{\multicolumn{2}{|c|}{ Network measures }} & \multirow{2}{*}{$\begin{array}{c}\text { Level of } \\
\text { effort }\end{array}$} & \multicolumn{2}{|c|}{ Willingness to cooperate } \\
\hline & & & Round 1 & Round 2 \\
\hline Score & & $0.13 * * *$ & 0.03 & $0.11 * * *$ \\
\hline \multirow{6}{*}{$\begin{array}{c}\text { Connectivity } \\
\text { in the group } \\
\text { A. B, C }\end{array}$} & Number of connections & $0.18 * * *$ & 0.05 & $0.07 *$ \\
\hline & Number of friends & $0.14 * * *$ & 0.06 & 0.04 \\
\hline & Number of relatives & $0.10 * * *$ & $0.09 * *$ & 0.02 \\
\hline & Number of acquaintances & $0.15 * * *$ & $0.07 *$ & $0.14 * * *$ \\
\hline & If anyone consider the player a leader & 0.00 & -0.05 & -0.04 \\
\hline & Number of people considered trustworthy & $0.08 * *$ & 0.03 & 0.03 \\
\hline \multirow{6}{*}{$\begin{array}{l}\text { Connectivity } \\
\text { in the session } \\
\text { (for the PGG) }\end{array}$} & Number of connections & $0.12 * * *$ & 0.02 & $0.10 * * *$ \\
\hline & Number of friends & $0.11 * * *$ & 0.03 & $0.11 * * *$ \\
\hline & Number of relatives & $0.06^{*}$ & 0.02 & 0.01 \\
\hline & Number of acquaintances & -0.01 & -0.03 & 0.01 \\
\hline & If anyone consider the player a leader & 0.03 & -0.02 & -0.04 \\
\hline & Number of people considered trustworthy & $0.12 * * *$ & 0.05 & $0.08 * *$ \\
\hline
\end{tabular}

* Significant at $10 \%$; ** significant at 5\%; *** significant at $1 \%$. 
Table A.3 a Effect of exposure to the program (1 if the player has been in the program for more than a year) on social capital measures. Dummy Survey measures (marginal effects of probit regression reported)

\begin{tabular}{|c|c|c|c|c|c|c|c|c|c|c|}
\hline \multicolumn{3}{|c|}{ Dependent variable } & I & III & IV & VI & VII & IX & $\mathrm{X}$ & XII \\
\hline \multicolumn{3}{|c|}{ Participation in neighborhood decisions } & 0.04 & 0.03 & 0.03 & 0.02 & 0.04 & 0.03 & 0.04 & 0.03 \\
\hline \multicolumn{3}{|c|}{ Participation in the neighborhood meetings } & $0.06^{*}$ & 0.03 & $0.05^{*}$ & 0.03 & 0.05 & 0.03 & $0.06^{*}$ & 0.03 \\
\hline \multicolumn{3}{|c|}{ Membership in at least one organization } & $0.15 * * *$ & $0.12 * *$ & $0.15^{* * *}$ & $0.13 * *$ & $0.16 * * *$ & $0.13 * *$ & $0.15 * * *$ & $0.12 * *$ \\
\hline \multicolumn{3}{|c|}{ Bridging Social capital } & $0.11 * * *$ & $0.09 * *$ & $0.11 * *$ & $0.09 * *$ & $0.11 * * *$ & $0.09 * *$ & $0.11 * * *$ & $0.08 * *$ \\
\hline \multicolumn{3}{|c|}{ Linking Social capital } & 0.02 & 0.01 & 0.02 & 0.01 & 0.02 & 0.01 & 0.02 & 0.01 \\
\hline \multicolumn{3}{|c|}{ Membership in a charity } & 0.02 & 0.02 & 0.02 & 0.02 & 0.02 & 0.02 & 0.02 & 0.02 \\
\hline \multicolumn{3}{|c|}{ Membership in a religious association } & $0.06 * *$ & $0.05^{*}$ & $0.07 * * *$ & $0.06^{* *}$ & $0.06 * *$ & $0.05^{*}$ & $0.06 * *$ & $0.05^{*}$ \\
\hline \multicolumn{3}{|c|}{ Membership in a community action association } & 0.02 & 0.01 & 0.02 & 0.01 & 0.01 & 0.01 & 0.01 & 0.01 \\
\hline \multicolumn{3}{|c|}{ Voted in local elections (2007) } & 0.01 & 0.01 & 0.02 & 0.01 & 0.01 & 0.01 & 0.01 & 0.01 \\
\hline \multicolumn{3}{|c|}{ Voted in presidential elections (2006) } & $0.17 * * *$ & $0.18 * * *$ & $0.19 * * *$ & $0.20 * * *$ & $0.17 * * *$ & $0.17 * * *$ & $0.17 * * *$ & $0.18 * * *$ \\
\hline \multirow{3}{*}{\multicolumn{2}{|c|}{$\begin{array}{l}\text { Trust: do you } \\
\text { consider that you } \\
\text { can trust in? }\end{array}$}} & Most people & 0.03 & -0.00 & 0.02 & -0.01 & 0.03 & -0.01 & 0.03 & -0.00 \\
\hline & & Few people & -0.03 & -0.02 & -0.04 & -0.03 & -0.03 & -0.01 & -0.03 & -0.01 \\
\hline & & None & 0.00 & 0.02 & 0.02 & 0.03 & 0.00 & 0.02 & 0.00 & 0.02 \\
\hline \multirow{2}{*}{\multicolumn{2}{|c|}{$\begin{array}{l}\text { Perception within } \\
\text { the community }\end{array}$}} & Cooperation & -0.02 & -0.03 & -0.01 & -0.02 & -0.03 & -0.04 & -0.02 & -0.03 \\
\hline & & Reciprocity & 0.03 & 0.04 & 0.02 & 0.04 & 0.03 & 0.04 & 0.03 & 0.04 \\
\hline \multirow{4}{*}{$\begin{array}{l}\text { Always or } \\
\text { usually, has } \\
\text { she helped }\end{array}$} & by & ffering her seat in the bus & 0.00 & 0.03 & 0.00 & 0.03 & 0.00 & 0.03 & 0.01 & 0.03 \\
\hline & som & eone with domestic work & $0.05^{*}$ & 0.06 & $0.05^{*}$ & 0.05 & $0.06 * *$ & 0.06 & $0.05 * *$ & 0.06 \\
\hline & som & eone by carrying stuff & $0.04 * *$ & 0.02 & 0.03 & 0.01 & $0.04 * * *$ & 0.02 & $0.04 * * *$ & 0.02 \\
\hline & son & eone with childcare & 0.01 & -0.00 & -0.01 & -0.02 & 0.01 & 0.00 & 0.01 & -0.00 \\
\hline \multirow{4}{*}{$\begin{array}{c}\text { CCT } \\
\text { program } \\
\text { measures }\end{array}$} & She is & a ML & 0.00 & -0.00 & 0.00 & -0.00 & 0.00 & -0.01 & 0.00 & -0.00 \\
\hline & She h & $\mathrm{s}$ attended to EC meetings & $0.24 * * *$ & $0.23 * * *$ & $0.25 * * *$ & $0.24 * * *$ & $0.24 * * *$ & $0.22 * * *$ & $0.24 * * *$ & $0.23 * * *$ \\
\hline & If any & ne consider the player a leader & 0.04 & 0.03 & 0.03 & 0.03 & 0.04 & 0.03 & 0.04 & 0.03 \\
\hline & There & is at least a ML in the session & 0.00 & 0.02 & -0.01 & 0.01 & 0.02 & 0.03 & 0.01 & 0.02 \\
\hline \multirow{5}{*}{\multicolumn{2}{|c|}{ Controls }} & Basic Characteristics & No & Yes & No & Yes & No & Yes & No & Yes \\
\hline & & Network information & No & Yes & No & Yes & No & Yes & No & Yes \\
\hline & & Effort decision & No & No & Yes & Yes & No & No & No & No \\
\hline & & Cooperation decision in round 1 & No & No & No & No & Yes & Yes & No & No \\
\hline & & Cooperation decision in round 2 & No & No & No & No & No & No & Yes & Yes \\
\hline
\end{tabular}


Table A.3 b. Effect of exposure to the program ( 1 if the player has been in the program for more than a year) on social capital measures. Continuous survey measures (Linear regression coefficients reported)

\begin{tabular}{|c|c|c|c|c|c|c|c|c|c|c|}
\hline Dependent var & able & I & III & IV & VI & VII & IX & $\mathrm{X}$ & XI & XII \\
\hline $\begin{array}{l}\text { CCT program } \\
\text { measures }\end{array}$ & $\begin{array}{l}\text { Number of meetings she has attended } \\
\% \text { of ML in the session }\end{array}$ & $\begin{array}{l}4.02 * * * \\
0.05 * * *\end{array}$ & $\begin{array}{l}2.85 * * * \\
-0.00\end{array}$ & $\begin{array}{l}4.01 * * * \\
0.05 * * *\end{array}$ & $\begin{array}{l}2.90 * * * \\
-0.00\end{array}$ & $\begin{array}{l}3.83 * * * \\
0.04 * * *\end{array}$ & $\begin{array}{l}2.87 * * * \\
-0.00\end{array}$ & $\begin{array}{l}3.84 * * * \\
0.04 * * *\end{array}$ & $\begin{array}{l}2.85 * * * \\
-0.00\end{array}$ & $\begin{array}{l}2.85 * * * \\
-0.00\end{array}$ \\
\hline $\begin{array}{l}\text { Connectivity } \\
\text { in the group } \\
\mathrm{A} . \mathrm{B}, \mathrm{C} \text { or } \\
\text { session }\end{array}$ & $\begin{array}{l}\text { Score } \\
\text { Number of connections } \\
\text { Number of friends } \\
\text { Number of relatives } \\
\text { Number of acquaintances } \\
\% \text { people who considered the player as leade } \\
\% \text { informal leaders in the group/session }\end{array}$ & $\begin{array}{l}5.45 * * * \\
2.10 * * * \\
1.46 * * * \\
0.14 * * * \\
0.50 * * * \\
0.01 * * * \\
0.20 * * *\end{array}$ & $\begin{array}{l}0.00 \\
0.03\end{array}$ & $\begin{array}{l}4.58 * * * \\
1.80 * * * \\
1.22 * * * \\
0.12 * * * \\
0.47 * * * \\
0.01 * * * \\
0.18 * * *\end{array}$ & $\begin{array}{l}0.00 \\
0.03\end{array}$ & $\begin{array}{l}4.52 * * * \\
1.76 * * * \\
1.20 * * * \\
0.12 * * * \\
0.44 * * * \\
0.01 * * * \\
0.17 * * * \\
\end{array}$ & $\begin{array}{l}0.00 \\
0.03\end{array}$ & $\begin{array}{l}4.32 * * * \\
1.69 * * * \\
1.14 * * * \\
0.12 * * * \\
0.43 * * * \\
0.01 * * * \\
0.17 * * *\end{array}$ & $\begin{array}{c}0.86 \\
0.37 \\
0.21 \\
0.02 \\
0.14^{*} \\
0.00 \\
0.03 \\
\end{array}$ & $\begin{array}{l}0.00 \\
0.03\end{array}$ \\
\hline Controls & $\begin{array}{l}\text { Exposure } \\
\text { Basic Characteristics } \\
\text { Network information } \\
\text { Effort decision } \\
\text { Cooperation decision round1 } \\
\text { Cooperation decision round2 }\end{array}$ & $\begin{array}{l}\text { Yes } \\
\text { No } \\
\text { No } \\
\text { No } \\
\text { No } \\
\text { No }\end{array}$ & $\begin{array}{l}\text { Yes } \\
\text { Yes } \\
\text { Yes } \\
\text { No } \\
\text { No } \\
\text { No }\end{array}$ & $\begin{array}{l}\text { Yes } \\
\text { No } \\
\text { No } \\
\text { Yes } \\
\text { No } \\
\text { No }\end{array}$ & $\begin{array}{l}\text { Yes } \\
\text { Yes } \\
\text { Yes } \\
\text { Yes } \\
\text { No } \\
\text { No }\end{array}$ & $\begin{array}{l}\text { Yes } \\
\text { No } \\
\text { No } \\
\text { No } \\
\text { Yes } \\
\text { No }\end{array}$ & $\begin{array}{l}\text { Yes } \\
\text { Yes } \\
\text { Yes } \\
\text { No } \\
\text { Yes } \\
\text { No }\end{array}$ & $\begin{array}{l}\text { Yes } \\
\text { No } \\
\text { No } \\
\text { No } \\
\text { No } \\
\text { Yes }\end{array}$ & $\begin{array}{l}\text { Yes } \\
\text { Yes } \\
\text { No } \\
\text { No } \\
\text { No } \\
\text { Yes }\end{array}$ & $\begin{array}{l}\text { Yes } \\
\text { Yes } \\
\text { Yes } \\
\text { No } \\
\text { No } \\
\text { Yes }\end{array}$ \\
\hline
\end{tabular}

Robust Standard errors that are clustered at the session level in parenthesis. * Significant at 10\%;** significant at 5\%; *** significant at $1 \%$.

Table A.4. a. Relation between willingness to cooperate and Social capital measures. Continuous survey measures (Linear regression coefficients reported)

\begin{tabular}{|c|c|c|c|c|c|c|c|}
\hline \multirow{2}{*}{\multicolumn{2}{|c|}{$\begin{array}{l}\text { Independent variable: } \\
\text { Dependent variable }\end{array}$}} & \multicolumn{3}{|c|}{ Cooperation decision in round 1} & \multicolumn{3}{|c|}{ Cooperation decision in round 2} \\
\hline & & 1_C1 & 2_C1 & 4_C1 & 1_C2 & 2_C2 & 4_C2 \\
\hline \multirow{4}{*}{$\begin{array}{l}\mathrm{CCT} \text { program } \\
\text { measures }\end{array}$} & Number of meetings she has attended & $2.10 * * *$ & $0.85 * * *$ & 0.16 & $2.22 * * *$ & $0.68 * * *$ & 0.04 \\
\hline & $\%$ of ML in the session & $0.06 * * *$ & $0.04 * * *$ & $0.01 *$ & $0.06 * * *$ & $0.04 * * *$ & 0.01 \\
\hline & Score & $5.64 * * *$ & $4.17 * * *$ & 0.56 & $6.16 * * *$ & $4.43 * * *$ & 1.05 \\
\hline & Number of connections & $2.09 * * *$ & $1.52 * * *$ & 0.16 & $2.28 * * *$ & $1.61 * * *$ & 0.33 \\
\hline \multirow{11}{*}{$\begin{array}{c}\text { Connectivity in } \\
\text { the group A. B, } \\
\text { C or session }\end{array}$} & Degree of friends & $1.56 * * *$ & $1.16^{* * * *}$ & 0.16 & $1.71 * * *$ & $1.26 * * *$ & 0.32 \\
\hline & Degree of relatives & $0.14 * * *$ & $0.11 * * *$ & 0.03 & $0.13 * * *$ & $0.09 * * *$ & 0.01 \\
\hline & Degree of acquaintances & $0.39 * * *$ & $0.25 * * *$ & -0.03 & $0.44 * * *$ & $0.26 * * *$ & 0.01 \\
\hline & $\%$ people who considered the player as leader & $0.01 * * *$ & $0.01 * * *$ & -0.00 & $0.01 * * *$ & $0.01 *$ & -0.00 \\
\hline & $\%$ informal leaders in the group/session & $0.19 * * *$ & $0.14 * * *$ & $0.02 *$ & $0.17 * * *$ & $0.10 * * *$ & -0.01 \\
\hline & Beneficiary longer than a year (enrolment) & No & Yes & Yes & No & Yes & Yes \\
\hline & Basic Characteristics & No & No & Yes & No & No & Yes \\
\hline & Network information & No & No & No & No & No & No \\
\hline & Effort decision & No & No & No & No & No & No \\
\hline & Cooperation decision roundl & Yes & Yes & Yes & No & No & No \\
\hline & Cooperation decision round 2 & No & No & No & Yes & Yes & Yes \\
\hline
\end{tabular}


Table A.4. b Relation between willingness to cooperate and social capital measures (marginal effects of probit regression reported)

\begin{tabular}{|c|c|c|c|c|c|c|c|c|c|}
\hline \multirow{2}{*}{\multicolumn{2}{|c|}{$\begin{array}{l}\text { Independent variable: } \\
\text { Dependent variable: Dummy survey measures }\end{array}$}} & \multicolumn{4}{|c|}{ Cooperation decision in round 1} & \multicolumn{4}{|c|}{ Cooperation decision in round 2} \\
\hline & & 1 & $2 \_\mathrm{C} 1$ & 4_C1 & 5_C1 & $1 \_\mathrm{C} 2$ & $2 \_\mathrm{C} 2$ & 4_C2 & $5 \_\mathrm{C} 2$ \\
\hline \multicolumn{2}{|c|}{ Participation in neighborhood decisions } & -0.02 & -0.01 & -0.01 & -0.02 & 0.04 & 0.05 & 0.06 & 0.05 \\
\hline \multicolumn{2}{|c|}{ Participation in the neighborhood meetings } & -0.04 & -0.03 & -0.03 & -0.03 & 0.03 & 0.03 & 0.05 & 0.05 \\
\hline \multicolumn{2}{|c|}{ Membership in at least one organization } & 0.01 & 0.03 & 0.03 & 0.03 & 0.07 & $0.07 *$ & $0.07 * *$ & $0.07 *$ \\
\hline \multicolumn{2}{|c|}{ Bonding Social capital } & -0.00 & 0.01 & -0.01 & -0.00 & 0.05 & $0.05^{*}$ & $0.04 *$ & $0.04 *$ \\
\hline \multicolumn{2}{|l|}{ Bridging Social capital } & 0.00 & 0.02 & 0.02 & 0.02 & 0.06 & $0.06^{*}$ & $0.06 * *$ & $0.06 * *$ \\
\hline \multicolumn{2}{|l|}{ Linking Social capital } & -0.01 & -0.01 & -0.01 & -0.01 & 0.00 & 0.00 & -0.00 & -0.00 \\
\hline \multicolumn{2}{|l|}{ Membership in a charity } & 0.01 & 0.01 & 0.00 & 0.00 & $0.03 * *$ & $0.03 * *$ & $0.02 *$ & $0.02 * *$ \\
\hline \multicolumn{2}{|c|}{ Membership in a community action association } & -0.00 & -0.00 & -0.00 & -0.00 & 0.01 & 0.01 & 0.00 & 0.00 \\
\hline \multicolumn{2}{|c|}{ Voted in local elections (2007) } & -0.00 & -0.00 & -0.02 & -0.02 & 0.03 & 0.03 & 0.01 & 0.01 \\
\hline \multicolumn{2}{|c|}{ Voted in presidential elections (2006) } & -0.01 & 0.02 & -0.02 & -0.02 & 0.02 & 0.03 & 0.02 & 0.02 \\
\hline \multirow{3}{*}{$\begin{array}{l}\text { Trust: do you consider that } \\
\text { you can trust in? }\end{array}$} & Most people & -0.01 & -0.01 & -0.02 & -0.02 & -0.02 & -0.02 & -0.01 & -0.01 \\
\hline & Few people & 0.02 & 0.01 & 0.02 & 0.02 & -0.06 & -0.06 & -0.06 & -0.07 \\
\hline & None & -0.00 & -0.00 & -0.01 & -0.00 & $0.08 *$ & $0.08 *$ & $0.07 *$ & $0.08 *$ \\
\hline \multirow{2}{*}{$\begin{array}{l}\text { Perception within the } \\
\text { community }\end{array}$} & Cooperation & -0.02 & -0.03 & -0.05 & -0.05 & -0.02 & -0.02 & -0.03 & -0.03 \\
\hline & Reciprocity & -0.00 & 0.00 & 0.02 & 0.02 & 0.00 & 0.00 & 0.01 & 0.01 \\
\hline \multirow{4}{*}{$\begin{array}{c}\text { Always or usually, has she } \\
\text { helped }\end{array}$} & by offering her seat in the bus & -0.03 & -0.03 & -0.03 & -0.03 & $0.12 * * *$ & $0.12 * * *$ & $0.12 * * *$ & $0.12 * * *$ \\
\hline & someone with domestic work & 0.01 & 0.02 & 0.02 & 0.01 & $0.06^{* *}$ & $0.06 * *$ & $0.05^{*}$ & $0.05^{*}$ \\
\hline & someone by carrying stuff & 0.01 & 0.02 & 0.02 & 0.02 & $0.05 * *$ & $0.05 * *$ & $0.05^{* *}$ & $0.04 * *$ \\
\hline & someone by childcare & 0.03 & 0.03 & 0.04 & 0.03 & 0.05 & 0.05 & 0.06 & 0.05 \\
\hline \multirow{4}{*}{$\mathrm{CCT}$ program measures } & She is a ML & -0.01 & -0.01 & -0.01 & -0.01 & -0.02 & -0.02 & -0.02 & -0.02 \\
\hline & She has attended to EC meetings & $-0.10 * *$ & $-0.06^{*}$ & -0.04 & -0.04 & $-0.09 * *$ & $-0.09 * * *$ & $-0.07 * *$ & $-0.07 * * *$ \\
\hline & If anyone consider the player a leader & -0.02 & -0.01 & -0.01 & -0.01 & -0.04 & -0.04 & -0.04 & $-0.05^{*}$ \\
\hline & There is at least a ML & $0.14 * *$ & $0.15^{* *}$ & $0.15 * *$ & $0.15^{* *}$ & $0.17 * *$ & $0.17 * *$ & $0.17 * * *$ & $0.18 * * *$ \\
\hline \multirow{6}{*}{ Controls } & Beneficiary for longer than a year & No & Yes & Yes & Yes & No & Yes & Yes & Yes \\
\hline & Basic Characteristics & No & No & Yes & Yes & No & No & Yes & Yes \\
\hline & Network information & No & No & No & Yes & No & No & No & Yes \\
\hline & Effort decision & No & No & No & No & No & No & No & No \\
\hline & Cooperation decision roundl & Yes & Yes & Yes & Yes & No & No & No & No \\
\hline & Cooperation decision round 2 & No & No & No & No & Yes & Yes & Yes & Yes \\
\hline
\end{tabular}

Robust Standard errors that are clustered at the session level in parenthesis. * Significant at 10\%;** significant at 5\%; *** significant at $1 \%$ 
Table A.4. c. Relation between network variables and social capital measures (marginal effects of probit regression reported)

\begin{tabular}{|c|c|c|c|c|c|c|c|c|c|c|c|}
\hline \multicolumn{3}{|c|}{$\begin{array}{l}\text { Independent variable } \\
\text { Dependent variable: Dummy Survey measures }\end{array}$} & $\begin{array}{c}\text { 5_E } \\
\text { Friends }\end{array}$ & $\begin{array}{c}\text { 5_E } \\
\text { Relatives }\end{array}$ & $\begin{array}{c}\text { 5_E } \\
\text { Acquaint. }\end{array}$ & $\begin{array}{c}\text { 5_C1 } \\
\text { Friends }\end{array}$ & $\begin{array}{c}\text { 5_C1 } \\
\text { Relatives }\end{array}$ & $\begin{array}{c}\text { 5_C1 } \\
\text { Acquaint. }\end{array}$ & $\begin{array}{c}\text { 5_C2 } \\
\text { Friends }\end{array}$ & $\begin{array}{c}\text { 5_C2 } \\
\text { Relatives }\end{array}$ & $\begin{array}{c}\text { 5_C2 } \\
\text { Acquaint. }\end{array}$ \\
\hline \multicolumn{3}{|c|}{ Participation in neighborhood decisions } & $0.02 *$ & 0.08 & 0.02 & $0.02 *$ & 0.08 & 0.02 & $0.02 *$ & 0.08 & 0.02 \\
\hline \multicolumn{3}{|c|}{ Participation in the neighborhood meetings } & -0.00 & -0.01 & -0.01 & -0.00 & -0.01 & -0.01 & -0.00 & -0.01 & -0.01 \\
\hline \multicolumn{3}{|c|}{ Membership in at least one organization } & 0.00 & -0.00 & 0.02 & 0.00 & -0.00 & 0.02 & 0.00 & -0.00 & 0.02 \\
\hline \multicolumn{3}{|c|}{ Bonding Social capital } & 0.00 & -0.01 & 0.02 & 0.00 & -0.01 & 0.02 & 0.00 & -0.01 & 0.02 \\
\hline \multicolumn{3}{|c|}{ Bridging Social capital } & 0.01 & 0.03 & 0.01 & 0.01 & 0.03 & 0.01 & 0.01 & 0.03 & 0.01 \\
\hline \multicolumn{3}{|c|}{ Linking Social capital } & -0.00 & -0.01 & 0.00 & -0.00 & -0.01 & 0.00 & -0.00 & -0.01 & 0.00 \\
\hline \multicolumn{3}{|c|}{ Membership in a charity } & 0.00 & 0.00 & -0.00 & 0.00 & 0.00 & -0.00 & 0.00 & 0.00 & -0.00 \\
\hline \multicolumn{3}{|c|}{ Membership in a religious association } & 0.00 & -0.03 & $0.02 *$ & 0.00 & -0.03 & $0.02 *$ & 0.00 & -0.03 & $0.02 *$ \\
\hline \multicolumn{3}{|c|}{ Membership in a community action association } & $-0.01 * *$ & -0.00 & -0.00 & $-0.01 *$ & -0.00 & -0.00 & $-0.01 *$ & -0.00 & -0.00 \\
\hline \multicolumn{3}{|c|}{ Voted in local elections (2007) } & 0.01 & 0.05 & $0.03 *$ & 0.01 & 0.05 & $0.03 *$ & 0.01 & 0.05 & $0.03 *$ \\
\hline \multicolumn{3}{|c|}{ Voted in presidential elections (2006) } & 0.01 & $0.10 * *$ & 0.02 & 0.00 & $0.10 * *$ & 0.02 & 0.00 & $0.10 * *$ & 0.02 \\
\hline \multirow{3}{*}{\multicolumn{2}{|c|}{$\begin{array}{l}\text { Trust: do you } \\
\text { consider that you can } \\
\text { trust in? }\end{array}$}} & Most people & 0.00 & 0.00 & 0.00 & 0.00 & 0.00 & 0.00 & 0.00 & 0.00 & 0.00 \\
\hline & & Few people & $0.04 * * *$ & 0.01 & $0.03 *$ & $0.04 * * *$ & 0.01 & $0.03 *$ & $0.04 * * *$ & 0.01 & $0.04 *$ \\
\hline & & None & $-0.04 * * *$ & -0.01 & $-0.04 *$ & $-0.04 * * *$ & -0.01 & $-0.04 *$ & $-0.04 * * *$ & -0.01 & $-0.04 *$ \\
\hline \multirow{3}{*}{\multicolumn{2}{|c|}{$\begin{array}{l}\text { Perception within the } \\
\text { community }\end{array}$}} & Cooperation & 0.00 & $-0.08 *$ & -0.00 & 0.00 & $-0.08 *$ & -0.00 & 0.00 & $-0.08 *$ & -0.00 \\
\hline & & Reciprocity & 0.00 & 0.05 & 0.01 & 0.01 & 0.05 & 0.01 & 0.00 & 0.05 & 0.01 \\
\hline & & Self-regarding & -0.01 & 0.02 & -0.01 & -0.01 & 0.02 & -0.01 & -0.01 & 0.02 & -0.01 \\
\hline \multirow{5}{*}{$\begin{array}{l}\text { Always or } \\
\text { usually, has } \\
\text { she helped }\end{array}$} & $\begin{array}{l}\text { anyone } \\
\text { clothes }\end{array}$ & with money, food or & 0.00 & 0.00 & -0.00 & 0.00 & 0.00 & -0.00 & 0.00 & 0.01 & -0.00 \\
\hline & by offe & ring her seat in the bus & 0.01 & -0.01 & 0.03 & 0.01 & -0.01 & 0.03 & 0.01 & -0.01 & 0.03 \\
\hline & someor & e with domestic work & $0.01 *$ & -0.00 & -0.00 & $0.01 *$ & -0.00 & -0.00 & $0.01 *$ & -0.00 & -0.01 \\
\hline & someor & e by carrying stuff & 0.01 & 0.00 & 0.00 & 0.01 & 0.01 & 0.00 & 0.01 & 0.01 & 0.00 \\
\hline & someor & e by childcare & $0.03 * * *$ & 0.00 & $0.03 *$ & $0.03 * * *$ & 0.00 & $0.03 *$ & $0.03 * * *$ & 0.00 & $0.03 *$ \\
\hline \multirow{4}{*}{$\begin{array}{l}\text { CCT } \\
\text { program } \\
\text { measures }\end{array}$} & She is a & ML & 0.00 & 0.02 & -0.00 & 0.00 & 0.02 & -0.00 & 0.00 & 0.02 & -0.00 \\
\hline & She has & attended to EC meetings & 0.01 & 0.02 & 0.02 & 0.01 & 0.03 & 0.02 & 0.01 & 0.02 & 0.02 \\
\hline & If anyo & ne consider the player a leade & $0.02 * * *$ & 0.02 & $0.02 *$ & $0.02 * * *$ & 0.02 & $0.02 *$ & $0.02 * * *$ & 0.02 & $0.02 * *$ \\
\hline & There i & at least a ML in the session & -0.01 & 0.01 & 0.00 & -0.01 & 0.01 & 0.00 & -0.01 & 0.02 & 0.00 \\
\hline \multirow{6}{*}{ Controls } & Beneficiar & longer than a year & Yes & Yes & Yes & Yes & Yes & Yes & Yes & Yes & Yes \\
\hline & Basic Cha & racteristics & Yes & Yes & Yes & Yes & Yes & Yes & Yes & Yes & Yes \\
\hline & Network in & formation & Yes & Yes & Yes & Yes & Yes & Yes & Yes & Yes & Yes \\
\hline & Effort deci & sion & Yes & Yes & Yes & No & No & No & No & No & No \\
\hline & Cooperatic & n decision roundl & No & No & No & Yes & Yes & Yes & No & No & No \\
\hline & Cooperatic & n decision round 2 & No & No & No & No & No & No & Yes & Yes & Yes \\
\hline
\end{tabular}

Robust Standard errors that are clustered at the session level. * Significant at 10\%;* significant at 5\%; *** significant at $1 \%$. 
Table A.5. a. Marginal effects of probit regression model. Cooperation in round 1

\begin{tabular}{|c|c|c|c|c|c|c|c|}
\hline VARIABLES & I & II & III & IV & $\mathrm{V}$ & VI & VII \\
\hline Beneficiary longer than a year (enrolment) & $\begin{array}{l}-0.12 * \\
(0.07)\end{array}$ & $\begin{array}{l}-0.15^{* *} \\
(0.07)\end{array}$ & $\begin{array}{c}-0.14 * * * \\
(0.05)\end{array}$ & $\begin{array}{l}-0.12 * * \\
(0.06)\end{array}$ & $\begin{array}{l}-0.06 \\
(0.05)\end{array}$ & $\begin{array}{l}-0.04 \\
(0.04)\end{array}$ & $\begin{array}{c}-0.07 * \\
(0.04)\end{array}$ \\
\hline Cooperation decision round 2 & & & $\begin{array}{c}0.29 * * * \\
(0.08)\end{array}$ & & & & $\begin{array}{l}0.20 * * * \\
(0.08)\end{array}$ \\
\hline Degree of Player (friends) & & $\begin{array}{c}0.00 \\
(0.01)\end{array}$ & $\begin{array}{l}-0.00 \\
(0.01)\end{array}$ & & & $\begin{array}{c}0.01 \\
(0.01)\end{array}$ & $\begin{array}{l}-0.00 \\
(0.01)\end{array}$ \\
\hline Degree of Player (relatives) & & $\begin{array}{c}0.01 \\
(0.05)\end{array}$ & $\begin{array}{c}0.02 \\
(0.05)\end{array}$ & & & $\begin{array}{c}0.02 \\
(0.05)\end{array}$ & $\begin{array}{c}0.02 \\
(0.05)\end{array}$ \\
\hline Degree of Player (acquaintances) & & $\begin{array}{l}-0.01 \\
(0.02)\end{array}$ & $\begin{array}{l}-0.01 \\
(0.02)\end{array}$ & & & $\begin{array}{l}-0.02 \\
(0.02)\end{array}$ & $\begin{array}{c}-0.02 \\
(0.02)\end{array}$ \\
\hline Effort decision & & $\begin{array}{c}0.06 \\
(0.04)\end{array}$ & $\begin{array}{c}0.06 * * \\
(0.03)\end{array}$ & & & & $\begin{array}{c}0.03 \\
(0.03)\end{array}$ \\
\hline Beneficiary is a ML & & & & & & $\begin{array}{l}-0.07 \\
(0.05)\end{array}$ & $\begin{array}{l}-0.05 \\
(0.06)\end{array}$ \\
\hline There is at least $1 \mathrm{ML}$ in the session & & & & & & $\begin{array}{l}0.18 * * * \\
(0.04)\end{array}$ & $\begin{array}{c}0.16^{* * * *} \\
(0.04)\end{array}$ \\
\hline 1 if player is chosen as leader by anyone in the group & & & & & & $\begin{array}{l}-0.03 \\
(0.05)\end{array}$ & $\begin{array}{c}-0.02 \\
(0.05)\end{array}$ \\
\hline Percentage of informal leaders in the session & & & & & & $\begin{array}{c}0.14 \\
(0.23)\end{array}$ & $\begin{array}{c}0.28 \\
(0.21)\end{array}$ \\
\hline Basic characteristics & No & No & No & Yes & Yes & Yes & Yes \\
\hline Experimental variables & No & No & No & No & Yes & Yes & Yes \\
\hline Network Information & No & No & No & No & No & Yes & Yes \\
\hline Observations & 714 & 714 & 714 & 712 & 712 & 712 & 712 \\
\hline
\end{tabular}


Table A.5. b. Marginal effects of probit regression model. Cooperation in round 2

\begin{tabular}{|c|c|c|c|c|c|c|c|c|c|}
\hline VARIABLES & I & II & III & IV & $\mathrm{V}$ & VI & VII & VIII & IX \\
\hline Beneficiary longer than a year (enrolment) & $\begin{array}{c}-0.03 \\
(0.08)\end{array}$ & $\begin{array}{c}0.00 \\
(0.08)\end{array}$ & $\begin{array}{c}0.01 \\
(0.08)\end{array}$ & $\begin{array}{l}0.02 \\
(0.07)\end{array}$ & $\begin{array}{c}0.01 \\
(0.07)\end{array}$ & $\begin{array}{c}0.02 \\
(0.06)\end{array}$ & $\begin{array}{c}0.04 \\
(0.06)\end{array}$ & $\begin{array}{l}0.09 * \\
(0.05)\end{array}$ & $\begin{array}{c}0.10 * * \\
(0.05)\end{array}$ \\
\hline Cooperation decision round 1 & & $\begin{array}{l}0.28 * * * \\
(0.07)\end{array}$ & $\begin{array}{c}0.28 * * * \\
(0.07)\end{array}$ & $\begin{array}{c}0.28 * * * \\
(0.07)\end{array}$ & & $\begin{array}{c}0.21 * * * \\
(0.07)\end{array}$ & $\begin{array}{c}0.21 * * * \\
(0.07)\end{array}$ & $\begin{array}{c}0.19 * * * \\
(0.06)\end{array}$ & $\begin{array}{c}0.19 * * * \\
(0.06)\end{array}$ \\
\hline Degree of Player (friends) & & & $\begin{array}{l}0.02^{*} \\
(0.01)\end{array}$ & $\begin{array}{l}0.02 * \\
(0.01)\end{array}$ & & & & $\begin{array}{l}0.02 * \\
(0.01)\end{array}$ & $\begin{array}{l}0.02 * \\
(0.01)\end{array}$ \\
\hline Degree of Player (relatives) & & & $\begin{array}{l}-0.01 \\
(0.04)\end{array}$ & $\begin{array}{l}-0.01 \\
(0.04)\end{array}$ & & & & $\begin{array}{l}-0.02 \\
(0.05)\end{array}$ & $\begin{array}{l}-0.02 \\
(0.04)\end{array}$ \\
\hline Degree of Player (acquaintances) & & & $\begin{array}{c}0.01 \\
(0.01)\end{array}$ & $\begin{array}{c}0.01 \\
(0.01)\end{array}$ & & & & $\begin{array}{l}-0.01 \\
(0.01)\end{array}$ & $\begin{array}{l}-0.01 \\
(0.01)\end{array}$ \\
\hline Effort decision & & & & $\begin{array}{l}-0.02 \\
(0.04)\end{array}$ & & & $\begin{array}{l}-0.02 \\
(0.04)\end{array}$ & & $\begin{array}{l}-0.02 \\
(0.03)\end{array}$ \\
\hline Beneficiary is a ML & & & & & & & & $\begin{array}{c}-0.12 * * * \\
(0.04)\end{array}$ & $\begin{array}{c}-0.12 * * * \\
(0.04)\end{array}$ \\
\hline There is at least $1 \mathrm{ML}$ in the session & & & & & & & & $\begin{array}{l}0.17 * * * \\
\left(0.0^{\prime} 6\right)\end{array}$ & $\begin{array}{c}0.17 * * * \\
(0.06)\end{array}$ \\
\hline 1 if player is chosen as leader by anyone in the group & & & & & & & & $\begin{array}{l}-0.03 \\
(0.03)\end{array}$ & $\begin{array}{l}-0.03 \\
(0.03)\end{array}$ \\
\hline Percentage of informal leaders in the session & & & & & & & & $\begin{array}{l}-0.68 * \\
(0.36)\end{array}$ & $\begin{array}{l}-0.68 * \\
(0.36)\end{array}$ \\
\hline Basic characteristics & No & No & No & No & Yes & Yes & Yes & Yes & Yes \\
\hline Experimental variables & No & No & No & No & No & Yes & Yes & Yes & Yes \\
\hline Network Information & No & No & No & No & No & No & No & Yes & Yes \\
\hline Observations & 714 & 714 & 714 & 714 & 712 & 712 & 712 & 712 & 712 \\
\hline
\end{tabular}

Robust Standard errors that are clustered at the session level in parenthesis. * Significant at 10\%;** significant at 5\%; *** significant at $1 \%$. 
Table A.5. c. Control variables in Table A6a Marginal effects of a probit regression model.

\begin{tabular}{|c|c|c|c|c|}
\hline Independent Variable: Cooperation in round 1 & IV & $\mathbf{V}$ & VI & VII \\
\hline 1 if the player is a woman & $\begin{array}{c}0.06 \\
(0.10)\end{array}$ & $\begin{array}{l}0.13^{*} \\
(0.07)\end{array}$ & $\begin{array}{l}0.14 * * \\
(0.06)\end{array}$ & $\begin{array}{l}0.17 * * * \\
(0.04)\end{array}$ \\
\hline Age & $\begin{array}{l}0.01 * * * \\
(0.00)\end{array}$ & $\begin{array}{l}0.01 * * * \\
(0.00)\end{array}$ & $\begin{array}{l}0.01 * * * \\
(0.00)\end{array}$ & $\begin{array}{l}0.01 * * * \\
(0.00)\end{array}$ \\
\hline Level of education ( 0 to 5$)$ & $\begin{array}{l}-0.02 \\
(0.02)\end{array}$ & $\begin{array}{l}-0.03 * * \\
(0.02)\end{array}$ & $\begin{array}{l}-0.03^{*} \\
(0.02)\end{array}$ & $\begin{array}{l}-0.02 \\
(0.01)\end{array}$ \\
\hline Number of years living in the neighborhood & $\begin{array}{c}0.00 \\
(0.00)\end{array}$ & $\begin{array}{c}0.00 \\
(0.00)\end{array}$ & $\begin{array}{c}0.00 \\
(0.00)\end{array}$ & $\begin{array}{c}0.00 \\
(0.00)\end{array}$ \\
\hline 1 if the player is displaced (self-declared) & $\begin{array}{c}0.02 \\
(0.05)\end{array}$ & $\begin{array}{c}0.01 \\
(0.06)\end{array}$ & $\begin{array}{c}0.02 \\
(0.06)\end{array}$ & $\begin{array}{c}0.00 \\
(0.05)\end{array}$ \\
\hline 1 if the player is the head of household & $\begin{array}{l}-0.02 \\
(0.06)\end{array}$ & $\begin{array}{l}-0.02 \\
(0.06)\end{array}$ & $\begin{array}{l}-0.03 \\
(0.06)\end{array}$ & $\begin{array}{l}-0.03 \\
(0.06)\end{array}$ \\
\hline 1 if If the player has a partner & $\begin{array}{l}-0.07 \\
(0.06)\end{array}$ & $\begin{array}{l}-0.06 \\
(0.05)\end{array}$ & $\begin{array}{l}-0.06 \\
(0.05)\end{array}$ & $\begin{array}{l}-0.03 \\
(0.04)\end{array}$ \\
\hline Number of people per room & $\begin{array}{c}0.02 \\
(0.01)\end{array}$ & $\begin{array}{c}0.02 \\
(0.01)\end{array}$ & $\begin{array}{c}0.02 \\
(0.01)\end{array}$ & $\begin{array}{c}0.01 \\
(0.01)\end{array}$ \\
\hline 1 if the player has her own housing & $\begin{array}{l}-0.06 \\
(0.04)\end{array}$ & $\begin{array}{l}-0.05 \\
(0.03)\end{array}$ & $\begin{array}{l}-0.06^{*} \\
(0.03)\end{array}$ & $\begin{array}{l}-0.05 \\
(0.03)\end{array}$ \\
\hline 1 if the player's home has no electricity & $\begin{array}{l}0.18^{*} \\
(0.10)\end{array}$ & $\begin{array}{c}0.17 \\
(0.11)\end{array}$ & $\begin{array}{l}0.20^{*} \\
(0.11)\end{array}$ & $\begin{array}{c}0.18 \\
(0.11)\end{array}$ \\
\hline 1 if the player has a landline & $\begin{array}{l}-0.04 \\
(0.05)\end{array}$ & $\begin{array}{l}-0.05 \\
(0.05)\end{array}$ & $\begin{array}{l}-0.06 \\
(0.05)\end{array}$ & $\begin{array}{l}-0.05 \\
(0.05)\end{array}$ \\
\hline 1 if the player has a cellphone & $\begin{array}{c}0.03 \\
(0.04)\end{array}$ & $\begin{array}{c}0.01 \\
(0.03)\end{array}$ & $\begin{array}{l}-0.00 \\
(0.03)\end{array}$ & $\begin{array}{l}-0.01 \\
(0.03)\end{array}$ \\
\hline 1 if the player's home has water pipe access & $\begin{array}{c}0.00 \\
(0.06)\end{array}$ & $\begin{array}{l}-0.01 \\
(0.05)\end{array}$ & $\begin{array}{l}-0.01 \\
(0.05)\end{array}$ & $\begin{array}{l}-0.03 \\
(0.05)\end{array}$ \\
\hline 1 if the player's home has sewage & $\begin{array}{l}-0.03 \\
(0.04)\end{array}$ & $\begin{array}{c}0.00 \\
(0.03)\end{array}$ & $\begin{array}{c}0.00 \\
(0.03)\end{array}$ & $\begin{array}{l}-0.00 \\
(0.04)\end{array}$ \\
\hline 1 if She has received (different from FA) any other government aid & $\begin{array}{l}-0.04 \\
(0.03)\end{array}$ & $\begin{array}{l}-0.03 \\
(0.04)\end{array}$ & $\begin{array}{l}-0.03 \\
(0.04)\end{array}$ & $\begin{array}{l}-0.02 \\
(0.03)\end{array}$ \\
\hline Wealth perception ( 0 -the poorest, 1 -the richest) & $\begin{array}{c}0.10 \\
(0.07)\end{array}$ & $\begin{array}{c}0.05 \\
(0.07)\end{array}$ & $\begin{array}{c}0.05 \\
(0.07)\end{array}$ & $\begin{array}{c}0.06 \\
(0.08)\end{array}$ \\
\hline 1 if Perceives that $\mathrm{HH}$ income is above the average & $\begin{array}{l}-0.00 \\
(0.07)\end{array}$ & $\begin{array}{l}-0.04 \\
(0.07)\end{array}$ & $\begin{array}{l}-0.03 \\
(0.07)\end{array}$ & $\begin{array}{l}-0.03 \\
(0.08)\end{array}$ \\
\hline 1 if the $\mathrm{HH}$ has a sound player & $\begin{array}{c}0.00 \\
(0.04)\end{array}$ & $\begin{array}{c}0.01 \\
(0.04)\end{array}$ & $\begin{array}{c}-0.00 \\
(0.04)\end{array}$ & $\begin{array}{c}0.00 \\
(0.04)\end{array}$ \\
\hline HH income & $\begin{array}{c}0.00 \\
(0.00)\end{array}$ & $\begin{array}{c}0.00 \\
(0.00)\end{array}$ & $\begin{array}{c}0.00 \\
(0.00)\end{array}$ & $\begin{array}{c}0.00 \\
(0.00)\end{array}$ \\
\hline 1 if the $\mathrm{HH}$ has a DVD player & $\begin{array}{c}0.03 \\
(0.04)\end{array}$ & $\begin{array}{c}0.00 \\
(0.04)\end{array}$ & $\begin{array}{c}0.02 \\
(0.05)\end{array}$ & $\begin{array}{c}0.01 \\
(0.04)\end{array}$ \\
\hline 1 if there is at least one man in the group & & $\begin{array}{l}0.13 * * \\
(0.06)\end{array}$ & $\begin{array}{l}0.15 * * * \\
(0.05)\end{array}$ & $\begin{array}{l}0.13 * * * \\
(0.05)\end{array}$ \\
\hline 1 if Experimenter $n^{\circ} 2$ (female) in 2008 & & $\begin{array}{c}0.07 \\
(0.07)\end{array}$ & $\begin{array}{c}0.11 \\
(0.07)\end{array}$ & $\begin{array}{c}0.10 \\
(0.06)\end{array}$ \\
\hline 1 if the player understood the activity perfectly & & $\begin{array}{l}-0.05 \\
(0.04)\end{array}$ & $\begin{array}{l}-0.06 \\
(0.04)\end{array}$ & $\begin{array}{l}-0.06 \\
(0.04)\end{array}$ \\
\hline Number of players in session & & $\begin{array}{l}-0.06^{* *} \\
(0.02)\end{array}$ & $\begin{array}{c}-0.07 * * * \\
(0.02)\end{array}$ & $\begin{array}{c}-0.06 * * * \\
(0.02)\end{array}$ \\
\hline 1 if First session in the day & & $\begin{array}{l}0.23 * * * \\
(0.07)\end{array}$ & $\begin{array}{l}0.18 * * * \\
(0.07)\end{array}$ & $\begin{array}{l}0.13 * * \\
(0.06)\end{array}$ \\
\hline Average level of cooperation in the last two sessions ${ }^{\text {a }}$ & & $\begin{array}{c}0.30 * * \\
(0.14)\end{array}$ & $\begin{array}{l}0.27 * \\
(0.14)\end{array}$ & $\begin{array}{c}0.20 \\
(0.13)\end{array}$ \\
\hline Participant socioeconomic characteristics & Yes & Yes & Yes & Yes \\
\hline Experimental variables & No & Yes & Yes & Yes \\
\hline Network Information & No & No & Yes & Yes \\
\hline Observations & 712 & 712 & 712 & 712 \\
\hline
\end{tabular}

Robust Standard errors that are clustered at the session level in parenthesis. * Significant at $10 \% ; * *$ significant at $5 \%$; *** significant at $1 \%$. 
Table A.5. d. Control variables in Table A6b Marginal effects of a probit regression model.

\begin{tabular}{|c|c|c|c|c|c|}
\hline Indep. Variable: Cooperation in Round 2 & V & VI & VII & VIII & $\mathbf{I X}$ \\
\hline 1 if the player is a woman & $\begin{array}{l}-0.24 \\
(0.18)\end{array}$ & $\begin{array}{l}-0.19 \\
(0.18)\end{array}$ & $\begin{array}{l}-0.19 \\
(0.18)\end{array}$ & $\begin{array}{l}-0.19 \\
(0.19)\end{array}$ & $\begin{array}{l}-0.19 \\
(0.20)\end{array}$ \\
\hline Age & 0.00 & -0.00 & -0.00 & -0.00 & -0.00 \\
\hline & $(0.00)$ & $(0.00)$ & $(0.00)$ & $(0.00)$ & $(0.00)$ \\
\hline Level of education ( 0 to 5 ) & $\begin{array}{l}-0.01 \\
(0.02)\end{array}$ & $\begin{array}{l}-0.01 \\
(0.01)\end{array}$ & $\begin{array}{l}-0.01 \\
(0.01)\end{array}$ & $\begin{array}{l}-0.01 \\
(0.01)\end{array}$ & $\begin{array}{l}-0.01 \\
(0.01)\end{array}$ \\
\hline Number of years living in the neighborhood & $\begin{array}{c}0.00 \\
(0.00)\end{array}$ & $\begin{array}{c}0.00 \\
(0.00)\end{array}$ & $\begin{array}{c}0.00 \\
(0.00)\end{array}$ & $\begin{array}{c}0.00 \\
(0.00)\end{array}$ & $\begin{array}{c}0.00 \\
(0.00)\end{array}$ \\
\hline 1 if the player is displaced (self-declared) & $\begin{array}{c}0.08 \\
(0.06)\end{array}$ & $\begin{array}{c}0.05 \\
(0.06)\end{array}$ & $\begin{array}{c}0.05 \\
(0.06)\end{array}$ & $\begin{array}{c}0.07 \\
(0.05)\end{array}$ & $\begin{array}{c}0.07 \\
(0.05)\end{array}$ \\
\hline 1 if the player is the head of household & $\begin{array}{c}0.00 \\
(0.04)\end{array}$ & $\begin{array}{c}0.02 \\
(0.03)\end{array}$ & $\begin{array}{c}0.02 \\
(0.03)\end{array}$ & $\begin{array}{c}0.01 \\
(0.03)\end{array}$ & $\begin{array}{c}0.01 \\
(0.03)\end{array}$ \\
\hline 1 if If the player has a partner & $\begin{array}{l}-0.15^{* * * *} \\
(0.05)\end{array}$ & $\begin{array}{l}-0.12 * * \\
(0.05)\end{array}$ & $\begin{array}{l}-0.12 * * \\
(0.05)\end{array}$ & $\begin{array}{l}-0.13^{* * * *} \\
(0.05)\end{array}$ & $\begin{array}{c}-0.13^{* * *} \\
(0.05)\end{array}$ \\
\hline Number of people per room & $\begin{array}{c}0.00 \\
(0.01)\end{array}$ & $\begin{array}{l}-0.00 \\
(0.01)\end{array}$ & $\begin{array}{l}-0.00 \\
(0.01)\end{array}$ & $\begin{array}{l}-0.00 \\
(0.01)\end{array}$ & $\begin{array}{l}-0.00 \\
(0.01)\end{array}$ \\
\hline 1 if the player has her own housing & $\begin{array}{l}-0.04 \\
(0.03)\end{array}$ & $\begin{array}{l}-0.02 \\
(0.03)\end{array}$ & $\begin{array}{l}-0.02 \\
(0.03)\end{array}$ & $\begin{array}{l}-0.03 \\
(0.04)\end{array}$ & $\begin{array}{l}-0.02 \\
(0.04)\end{array}$ \\
\hline 1 if the player's home has no electricity & $\begin{array}{c}0.12 \\
(0.10)\end{array}$ & $\begin{array}{c}0.09 \\
(0.09)\end{array}$ & $\begin{array}{c}0.09 \\
(0.09)\end{array}$ & $\begin{array}{c}0.09 \\
(0.09)\end{array}$ & $\begin{array}{c}0.09 \\
(0.09)\end{array}$ \\
\hline 1 if the player has a landline & $\begin{array}{c}0.03 \\
(0.04)\end{array}$ & $\begin{array}{c}0.04 \\
(0.03)\end{array}$ & $\begin{array}{c}0.04 \\
(0.03)\end{array}$ & $\begin{array}{c}0.04 \\
(0.04)\end{array}$ & $\begin{array}{l}0.03 \\
(0.03)\end{array}$ \\
\hline 1 if the player has a cellphone & $\begin{array}{l}0.08 * * \\
(0.03)\end{array}$ & $\begin{array}{l}0.07 * * \\
(0.03)\end{array}$ & $\begin{array}{l}0.07 * * \\
(0.03)\end{array}$ & $\begin{array}{l}0.06^{*} \\
(0.03)\end{array}$ & $\begin{array}{l}0.06^{*} \\
(0.03)\end{array}$ \\
\hline 1 if the player's home has water pipe access & $\begin{array}{c}0.06 \\
(0.05)\end{array}$ & $\begin{array}{c}0.06 \\
(0.05)\end{array}$ & $\begin{array}{c}0.06 \\
(0.05)\end{array}$ & $\begin{array}{c}0.06 \\
(0.05)\end{array}$ & $\begin{array}{c}0.07 \\
(0.05)\end{array}$ \\
\hline 1 if the player's home has sewage & $\begin{array}{l}-0.03 \\
(0.05)\end{array}$ & $\begin{array}{l}-0.00 \\
(0.04)\end{array}$ & $\begin{array}{l}-0.00 \\
(0.04)\end{array}$ & $\begin{array}{c}0.00 \\
(0.04)\end{array}$ & $\begin{array}{c}0.00 \\
(0.04)\end{array}$ \\
\hline $\begin{array}{l}1 \text { if She has received (different from FA) any other } \\
\text { government aid }\end{array}$ & $\begin{array}{l}-0.07 * * \\
(0.03) \\
-0.02\end{array}$ & $\begin{array}{l}-0.06 * * \\
(0.03) \\
-0.05\end{array}$ & $\begin{array}{l}-0.06 * * \\
(0.03) \\
-0.04\end{array}$ & $\begin{array}{l}-0.07 * * \\
(0.03) \\
-0.03\end{array}$ & $\begin{array}{l}-0.07 * * \\
(0.03) \\
-0.03\end{array}$ \\
\hline $\begin{array}{l}\text { Wealth perception ( } 0 \text {-the poorest, } 1 \text {-the richest) } \\
1 \text { if Perceives that } \mathrm{HH} \text { income is above the average }\end{array}$ & $\begin{array}{c}(0.08) \\
0.03 \\
(0.07)\end{array}$ & $\begin{array}{c}(0.08) \\
0.02 \\
(0.07)\end{array}$ & $\begin{array}{c}(0.08) \\
0.02 \\
(0.07)\end{array}$ & $\begin{array}{c}(0.08) \\
0.01 \\
(0.07)\end{array}$ & $\begin{array}{c}(0.08) \\
0.01 \\
(0.07)\end{array}$ \\
\hline 1 if the $\mathrm{HH}$ has a soundplayer & $\begin{array}{c}0.02 \\
(0.04)\end{array}$ & $\begin{array}{c}0.00 \\
(0.04)\end{array}$ & $\begin{array}{c}0.00 \\
(0.04)\end{array}$ & $\begin{array}{l}-0.02 \\
(0.04)\end{array}$ & $\begin{array}{l}-0.02 \\
(0.04)\end{array}$ \\
\hline HH income & $\begin{array}{l}-0.00 \\
(0.00)\end{array}$ & $\begin{array}{l}-0.00 \\
(0.00)\end{array}$ & $\begin{array}{l}-0.00 \\
(0.00)\end{array}$ & $\begin{array}{l}-0.00 \\
(0.00)\end{array}$ & $\begin{array}{l}-0.00 \\
(0.00)\end{array}$ \\
\hline 1 if the $\mathrm{HH}$ has a DVD player & $\begin{array}{c}0.04 \\
(0.03)\end{array}$ & $\begin{array}{c}0.01 \\
(0.03)\end{array}$ & $\begin{array}{c}0.01 \\
(0.03)\end{array}$ & $\begin{array}{c}0.03 \\
(0.03)\end{array}$ & $\begin{array}{c}0.03 \\
(0.03)\end{array}$ \\
\hline 1 if there is at least one man in the group & & $\begin{array}{c}0.12 \\
(0.09)\end{array}$ & $\begin{array}{c}0.12 \\
(0.09)\end{array}$ & $\begin{array}{l}0.14 * \\
(0.07)\end{array}$ & $\begin{array}{l}0.13^{*} \\
(0.07)\end{array}$ \\
\hline 1 if Experimenter $n^{\circ} 2$ (female) in 2008 & & $\begin{array}{l}-0.03 \\
(0.07)\end{array}$ & $\begin{array}{l}-0.02 \\
(0.07)\end{array}$ & $\begin{array}{c}0.06 \\
(0.05)\end{array}$ & $\begin{array}{c}0.07 \\
(0.06)\end{array}$ \\
\hline 1 if the player understood the activity perfectly & & $\begin{array}{c}0.01 \\
(0.05)\end{array}$ & $\begin{array}{c}0.01 \\
(0.06)\end{array}$ & $\begin{array}{c}0.02 \\
(0.05)\end{array}$ & $\begin{array}{c}0.02 \\
(0.05)\end{array}$ \\
\hline Number of players in session & & $\begin{array}{c}0.02 \\
(0.03)\end{array}$ & $\begin{array}{c}0.02 \\
(0.03)\end{array}$ & $\begin{array}{c}0.00 \\
(0.04)\end{array}$ & $\begin{array}{l}-0.00 \\
(0.04)\end{array}$ \\
\hline 1 if First session in the day & & $\begin{array}{l}0.26 * * * \\
(0.07)\end{array}$ & $\begin{array}{c}0.26^{* * *} * \\
(0.07)\end{array}$ & $\begin{array}{l}0.24 * * * \\
(0.07)\end{array}$ & $\begin{array}{l}0.24 * * * \\
(0.07)\end{array}$ \\
\hline Average level of cooperation in the last two sessions ${ }^{\text {a }}$ & & $\begin{array}{c}0.20 \\
(0.13)\end{array}$ & $\begin{array}{l}0.22^{*} \\
(0.13)\end{array}$ & $\begin{array}{c}0.14 \\
(0.13)\end{array}$ & $\begin{array}{c}0.17 \\
(0.13)\end{array}$ \\
\hline Participant socioeconomic characteristics & Yes & Yes & Yes & Yes & Yes \\
\hline Experimental variables & No & Yes & Yes & Yes & Yes \\
\hline Network Information & No & No & No & Yes & Yes \\
\hline Observations & 712 & 712 & 712 & 712 & 712 \\
\hline
\end{tabular}

Robust Standard errors that are clustered at the session level in parenthesis. * Significant at $10 \%$;* significant at $5 \%$; *** significant at $1 \%$. 
Table A.6. Calibrated of the sensitivity parameter $\hat{\lambda}$

\begin{tabular}{cl|cc}
\hline \multicolumn{1}{c|}{$\hat{\lambda}$} & \multicolumn{2}{|c}{ Initial Condition } \\
Individual & Short exposure & 0 & 0 \\
Characteristic & Long exposure & 0 & 200 \\
\hline
\end{tabular}

vii. Experimental Instructions

The sentences in italic are not read in public; they are instructions for a supervisor and coordinators.

The supervisor introduces the team, the session and reads the consent form in order to obtain oral consent.

Exercise 1 (The Public Goods Game) (Attanasio et al. 2009, 2015)

You are going to take part in the first exercise that consists of two decision rounds. Now, we will describe in detail the process that will be repeated in all two decision rounds.

In each round each participant in this room will make a decision in an individual, simultaneous, and silent way. In the beginning of each round, you will be endowed with one token which you will be asked to invest in one of two accounts: a Private (and individual) Account or a Group Account.

Your earnings will partly depend on your decisions and partly on the decisions of the other participants in this room. Specifically, your earnings in each round will depend on the number of tokens in your Private Account and on the total number of tokens in the Group Account in the following way:

- You earn \$5,000 if you invest (put) your token in the Private Account.

- For each token that you and other participants invest (put) in the Group Account, every participant will obtain $\$ 400$.

Note again that each decision is individual and that you should make your own decision without consulting other participants and without announcing where you have put the token: in the Private or in the Group Account.

Now we are going to explain you how to make a decision. Each participant will receive two cards like these.

Show two cards on both sides. Explain that each card has a participation number and a round number. (See Figure A2)

One of the cards has the word "MY TOKEN" written on one side, called henceforth the MY TOKEN card, and the other card has a blank side, called henceforth the BLANK card. When everyone is ready to make a decision, one coordinator will go around the room with a bag to collect one card from each of you.

Show a bag. Explain that this bag indicates the Group Account.

If you want to invest your token in the Private Account, you just need to keep the MY TOKEN card in your pocket and put the BLANK card in the bag. Alternatively, if you want to invest your token in the Group Account, then you need to put the MY TOKEN card in the bag and keep the BLANK card in your pocket.

Once every participant has put one card in the bag, coordinators will count how many tokens have been 
placed in the Group Account, that is, how many MY TOKEN cards have been put in the bag. The number of tokens that have been placed in the Group Account in this round will not be revealed until the end of all two exercises. This information will be publicly announced at the end of all the exercises when we compute your total earnings.

\section{Figure A. 3. Public Goods game Decision cards.}

a. Decision cards for the placer no. 15 in the first round: [MY TOKEN], [Round], [Player number]

One card (both sides)

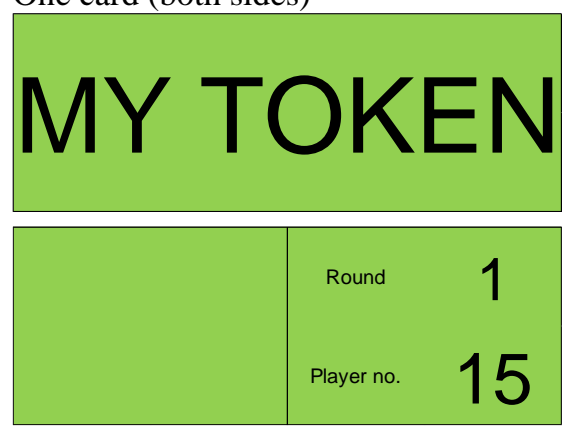

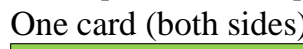

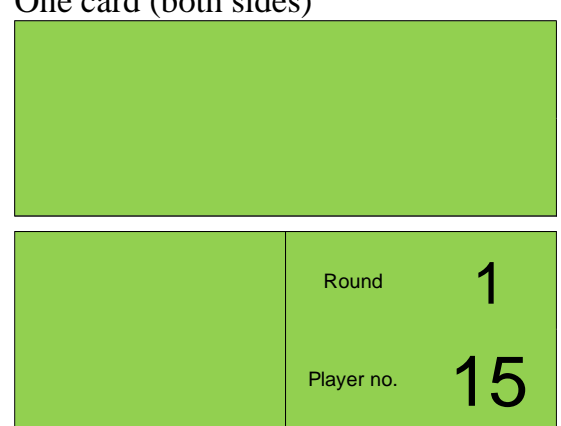

b. Decision cards for the placer no. 15 in the second round: [MY TOKEN], [Round 2], [Player number 15]

One card (both sides)
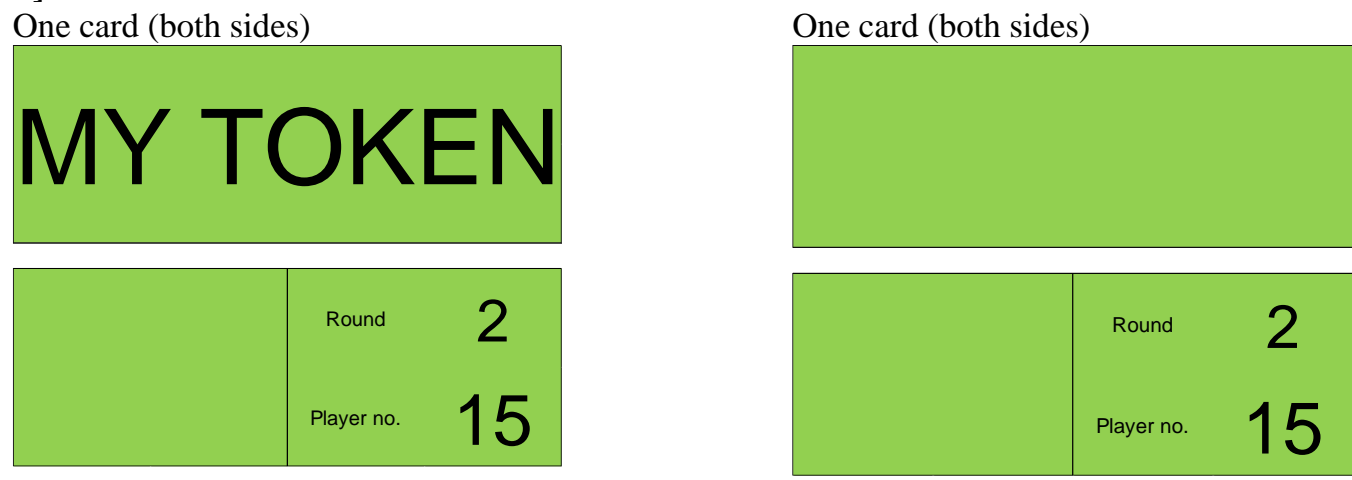

Note that you will retain one card after you have made a decision, regardless of where you have put the token. Please keep one remaining card by the end of today's activities. We will use the card you retain when we compute your earnings. Please do not show any other participants the card you have retained. This entire procedure of decision making is intended to make sure that other participants will not know what decision you have made.

You will explain this exercise further with several examples below. Please remember not to use extreme examples such as the case in which all the participants put their tokens in the Group Account and the case in which all the participants put their tokens in the Private Account. If a participant asks a question by referring to one of these examples, reply to that question by giving afterwards the other example showing what happens in the other situation, and write down the occurrence in the session log.

Please do not skip any examples but go through all examples as in the instructions. Please make sure that all understand the exercise by using the examples below. It is not necessary to follow script by script in each example. However, it is necessary to use the same values in each example that are shown in the instructions.

Now let's take several examples to see how the exercise works. Please pay careful attention and feel free to ask any question if you do not understand examples. Throughout the examples, we will assume that there are 25 participants. 
Show which card one should put in each example. After each example a coordinator should show how one should fold the card so that a coordinator cannot read the card.

- Suppose that you decided to invest your token in the Private Account. In other words, you have put the BLANK card in the bag and have kept the MY TOKEN card in your possession. After all the participants made their decisions, a coordinator will count how many MY TOKEN cards are in the bag. Suppose that there were 13 MY TOKEN cards in the bag. That is, 13 out of 25 people decided to put their tokens in the Group Account and the other 12 people (including you) decided to keep their tokens in their Private Accounts. Then, each participant will earn $\$ 5,200(=13 * \$ 400)$ pesos from the Group Account. Since you have decided to keep your token in your Private Account, you will earn \$5,000 pesos from the Private Account. Therefore, your earnings in this round are the sum of earnings from the Group Account and the Private Account, which is $\$ 5,200+\$ 5,000=\$ 10,200$ pesos.

- Now consider the same above example. Instead of calculating the earnings of participants who have kept their tokens in Private Accounts, let's consider a participant who invested his/her token to the Group Account. This participant will not receive any earnings from his/her Private Account since his/her token was not invested in his/her Private Account. Therefore, his/her earnings in this round are simply earnings from the Group Account: \$5,200 pesos.

- Now let's take another example. Suppose that you decided to invest your token in the Group Account. That is, you have put the MY TOKEN card in the bag. After all the participants made their decisions, a coordinator will count how many MY TOKEN card were put in the bag. Suppose that there were 20 MY TOKEN cards in the bag. That is, 20 out 25 people (including you) invested their tokens in the Group Account, while the other 5 people kept their tokens in their Private Accounts. Each participant will earn $\$ 8,000(=20 * \$ 400)$ pesos from the Group Account. Since your token was not invested in your Private Account, you earnings are determined by the earnings from the Group Account, which is $\$ 8,000$ pesos.

- Let's consider the same example but with a participant who kept the token in his/her Private Account. This participant earns $\$ 8,000$ pesos from the Group Account. In addition, he/she earns $\$ 5,000$ pesos from the Private Account since he/she invested the token in the Private Account. Therefore, the earnings for this participant are the sum of $\$ 8,000$ and $\$ 5,000$, which is $\$ 13,000$ pesos.

- Let's have one more example. Suppose that you decided to invest your token in your Private Account. That is, you have put the Blank card in the bag. After all the participants made their decisions, a coordinator will count how many MY TOKEN card were put in the bag. Suppose that there were 5 MY TOKEN cards in the bag. It means that 20 out of 25 people (including you) kept their tokens in their own Private Accounts and the other 5 participants invested their tokens to the Group Account. Then, each participant earns \$2,000 $\left(=5^{*} \$ 400\right)$ pesos from the Group Account. In addition, you earn $\$ 5,000$ pesos from your Private Account since you kept your token in the Private Account. Therefore, your earnings in this round are in total $\$ 7,000$.

- Now consider the same example but with a participant who invested the token to the Group Account, that is, who put the MY TOKEN card in the bag. This participant will earn $\$ 2,000$ pesos from the Group Account like all other participants. However, this participant will earn nothing from his/her Private Account since his/her token was not invested in his/her Private Account. Therefore, earnings for this participant in this round are $\$ 2,000$ pesos.

In summary, if you invest your token in the Group Account by putting your MY TOKEN card in the bag, every participant in this room will earn from your investment by $\$ 400$ pesos. Alternatively, if you invest your token in your Private Account by putting the Blank card in the bag, you will be the only one that earns $\$ 5,000$ from this decision. 
Is there any question?

Coordinators should make sure that all participants have understood the exercise itself and its procedure.

Shall we start the first exercise? Note again that your decisions are private: no other participant will know where you invest your own token. Please do not consult any other participants about what decisions you should make.

Let's start the first round of the exercise. Coordinators will hand out two cards (a MY TOKEN card and a BLANK card) for each participant. Remember that you keep one and put the other in the bag. Please do not throw away the card you decided to keep. You need to keep this card by the end of today's activities. We will compute your earnings at the end, using cards you have kept.

At this moment, coordinators distribute exercise cards to participants according to PARTICIPANT NUMBERs, that is, the order they were seated in the U. Please check if a number that is on two cards corresponds to an identification number of each participant. Check also that each coordinator delivers cards corresponding to a correct round.

Once all the participants have finished playing the first round, two coordinators count the numbers of blank cards and "MY TOKEN" cards in the bag. These coordinators should fill the MONITORS CALCULATION SHEET. Nothing is announced to participants at this point. Before initiating round 2 one of the coordinators should start taking care of the FINAL PAYMENTS SHEET (F6) outside the room and fill the payment receipts with full name and ID.

Important. When collecting cards, the coordinator should not have any physical contact with participants' cards. Each participant should put his/her card directly in the bag. Nevertheless, coordinators should verify if any participant has placed two cards in the bag or if there is a participant that has not decided yet. Coordinators inside the room cannot leave the group alone thus they cannot exit to count the results.

Please keep your retained card in your pocket by the end of today's activities. We will use this card when we compute your total earnings.

Now let's start the second round. Before the second round of this exercise, you will have an opportunity to communicate for 10 minutes with one or more participants in this room about this exercise. This communication is totally voluntary. After the 10-minute permitted time is over, all communications will be suspended. And we will proceed to the second round of this exercise. Coordinators will hand out two cards (a MY TOKEN card and a BLANK card) for each participant. Just as in the first round, you will just need to decide which card (either MY TOKEN card or BLANK card) you want to put in the bag. Again all decisions in this round will be private and be kept strictly confidential.

Past the 10 minutes, once all the participants have finished playing the second round, two coordinators should count how many blank cards and how many "MY TOKEN" cards there are in the bag. These two coordinators should fill the MONITORS CALCULATION SHEET and finish processing the PAYMENT SHEET.

Please keep this second round card safe, since we'll use these cards to calculate your earnings at the end of today's activities.

Today's first exercise is finished. Thank you all for the cooperation. 
Before participating in the second exercise, we will ask each of you to fill out a short form. While a coordinator works with you to fill out a form, you are offered snacks that we have prepared for you. It will take approximately 20 minutes. After that, we will start the second exercise.

At this moment coordinators start to help each participant fill out the network-connectivity questionnaire. When all the participants finished the survey, one coordinator will process the information of network connectivity to form 3 different sub groups. Another coordinator is filling up the PAYMENTS SHEET. The rest of coordinators start asking the postgame survey to participants.

\section{Exercise II (The Coordination game)}

Now you will participate in the second exercise. This exercise is independent of the first exercise which you already participated in. Your earnings in this exercise are not related to the decisions you made or earnings you obtained in the first exercise.

In this exercise, each of you will be assigned to one of three groups. Allocation into groups is determined by the coordinators. The allocation into groups will be announced after we explain the exercise. Each group will move to a separate classroom in order to participate in this exercise. After each group finishes the second exercise in a different classroom, we will meet all together again in this room and we will then proceed to calculate your earnings in the first exercise and in the second exercise.

Is there any question?

Shall we start?

This exercise consists of a single round in which you will make one decision. In this exercise, each participant in a group will make one decision, individually, simultaneously and in silence. Each participant will choose an individual level of effort to a Group Project. Any participant can neither see nor discuss what other participants in the group choose. There are three possible units of effort, $1,2,3$, where "1" may be interpreted as a low level of effort to the Group Project, "2" as a medium level of effort to the Group Project and " 3 " as a high level of effort to the Group Project. When you are ready to choose, you just need to mark with a cross $X$ the number you wish to choose in the YELLOW DECISION SHEET as this one (see figure A3). In this card, there is the player number and the three possible options of levels of effort. You will choose your low, medium or high level of effort marking the cell with a X.

\begin{tabular}{|c|c|c|c|}
\hline \multicolumn{3}{|c|}{ Exercise 2 } \\
\hline L1 & \multicolumn{2}{|c|}{ L9 } \\
\hline $\begin{array}{c}\text { Player } \\
\text { no. }\end{array}$ & \multicolumn{3}{|c|}{$\begin{array}{c}\text { My Decision } \\
\text { (level of effort) }\end{array}$} \\
\hline & 1 & 2 & 3 \\
\hline
\end{tabular}

Figure A. 4. Decision card, Minimum Effort game

Your earnings in this activity are determined as follows:

You will be in a group of 8 or 9 people.

At the beginning of the activity, each of you will have $\$ 3,000$.

Your earnings will depend on your decision and the lowest level of effort among all group members. Your earnings, given by these $\$ 3000$ may decrease depending on the level of effort you choose and increase depending on the minimum level of effort in the group. 
You decide the level of effort 1, 2 or 3 units of effort. You mark it on your yellow decision sheet. Once everyone in the group has made its decision, a coordinator will collect all yellow decision sheets.

We will know what the minimum level of effort is among all players in the group, this could be 1, 2, or 3 and multiply that minimum effort times $\$ 3000$ and each of you win that amount.

If the minimum effort in the group is 1, i.e. the lowest level of effort among all the people in the group is 1, i.e., at least 1 person chose the low level of effort, the earnings for everyone in the group are $\$ 3,000 *$ $1=\$ 3000$.

If the minimum effort in the group is 2, i.e. the lowest level of effort among all the people in the group is 2 , i.e., no one chose 1 and at least one person chose the medium level of effort, the earnings for everyone in the group are $\$ 3,000 * 2=\$ 6000$.

If the minimum effort in the group is 3 , i.e. the lowest level of effort among all the people in the group is 3 , i.e., no one chose either 1 or 2 and everyone chose 3 , the high level of effort, the earnings for everyone in the group are $\$ 3,000 * 3=\$ 9000$.

Then you must subtract from those earnings, according to your level of effort, $\$ 2,000$ for each unit of effort you decided to add to the group project.

Per unit effort you must subtract $\$ 2,000$ : If you choose 1 unit of effort, the cost of this unit is $(1 * 2000=$ $\$ 2000$ ) and you must subtract from your earnings \$2000. If you choose 2 units of effort, the cost of these two units is $(2 * 2000=\$ 4000)$ and you must subtract from your earnings $\$ 4,000$. If you choose 3 units of effort, the cost for these three units is $(3 * 2000=\$ 6000)$ and you must subtract from your earnings $\$ 6,000$.

Which can be summarized in the following table:

The coordinator will show the formula and table on a poster (See figure A5).

In summary, the calculation of your earnings can be seen as follows:

My Earnings $=\$ 3,000+\$ 3,000 \mathrm{X}$ the minimum effort in the group (the lowest level of effort among all group members) - $\$ 2,000 \mathrm{X}$ each unit effort

In brief, your earnings decrease the higher your level of effort and increase the higher the minimum effort in the group.

To help participants understand their earnings, the coordinator will use the examples in that order.

How should we read this table? Each row, called my decision of level of effort indicates the earnings you could obtain for different levels of the minimum effort in the group. For example, if you choose 3, you can either win $\$ 6,000, \$ 3,000$, or $\$ 0$. Each column indicates the earnings you could obtain for different minimum levels of effort in the group, i.e., the lowest effort among all effort levels chosen by the group. For example, if the minimum effort level chosen in the group is 2 , then you win or $\$ 3,000$ or $\$ 5,000$. 


\begin{tabular}{|c|c|c|c|c|}
\hline & $\mathrm{Ea}$ & \multicolumn{3}{|c|}{$\begin{array}{l}\text { Minimum level of effor } \\
\text { chosen by the group }\end{array}$} \\
\hline & & 3 & 2 & 1 \\
\hline \multirow{3}{*}{$\begin{array}{c}\text { My } \\
\text { decision } \\
\text { (level of } \\
\text { effort) } \\
\end{array}$} & 3 & $\$ 6$ & $\$ 3$ & $\$ 0$ \\
\hline & 2 & - & $\$ 5$ & $\$ 2$ \\
\hline & 1 & - & - & $\$ 4$ \\
\hline \multicolumn{5}{|c|}{$\$ 3$} \\
\hline+ & $\$ 3$ & \multirow{2}{*}{\multicolumn{3}{|c|}{$\begin{array}{l}x \text { Minimum level of effort } \\
\text { in the group } \\
x \text { My level of effort }\end{array}$}} \\
\hline - & $\$ 2$ & & & \\
\hline
\end{tabular}

\section{Figure A. 8 Poster for the Coordination Game}

Let's do some examples to understand how earnings are determined. Please pay close attention and feel free to ask if anything is not clear in the examples.

- Suppose you choose an effort level of 1 . Since you have chosen the lowest level of effort possible, the minimum effort in your group is 1 , regardless other levels of effort that the other participants have chosen. Then the group project benefit is $\$ 3,000$ for each member $(\$ 3,000 * 1)$. Furthermore, the cost of your own effort level that is subtracted from your earnings is $\$ 2,000(\$ 2,000 * 1)$. Therefore, your earnings will be $\$ 3,000+\$ 3,000-\$ 2,000=\$ 4,000$, which is where the row of your effort level 1 intersects with the minimal effort column equal to 1 .

- Suppose you choose an effort level 3, and the minimum effort in your group is 1, i.e. among all levels of effort in your group, the lowest one is 1 . This means that at least one participant in your group chose an effort level of 1 . Since the minimum level of effort in your group is 1 , the group project benefit is $\$ 3,000$ $(=\$ 3000 * 1)$ for each member. And as your own effort level is 3 , the cost of your effort that is subtracted from your earnings is $\$ 2000 * 3=\$ 6,000$. Therefore, your earnings will be $\$ 3,000+\$ 3,000-\$ 6,000=$ $\$ 0$, which is where the row of your effort level 3 intersects with the minimal effort column equal to 1 .

- Suppose you choose an effort level of 3 , and the minimum effort level in your group is 3 . This means that all participants (including yourself) in your group, chose an effort level of 3 . Then the group project benefit is $\$ 9000(=\$ 3.000 * 3)$ for each member. And as your own effort level is 3 , the cost of your effort that is subtracted from your earnings is $\$ 2000 * 3=\$ 6,000$. Therefore, your earnings will be $\$ 3,000+\$$ $9,000-\$ 6,000=\$ 6,000$, which is where the row of your effort level 3 intersects with the minimal effort column equal to 3 .

- Suppose you choose an effort level 2 and the minimum effort level in your group is 2 . This means that everyone in your group chose or 2 (like you) or 3 . Since the minimum effort in your group is 2 , the group project benefit is $\$ 6.000(=\$ 3.000 * 2)$ for each member. And as your own effort level is 2 , the cost of your effort that is subtracted from your earnings is $\$ 2000 * 2=\$ 4,000$. Therefore, your earnings will be $\$$ $3,000+\$ 6,000-\$ 4,000=\$ 5,000$, which is where the row of your effort level 2 intersects with the minimal effort column equal to 2 .

- Suppose you chose an effort level 2 and the minimum effort level in your group is 1, i.e. among all levels of effort in your group, the lowest one is 1 . This means that at least one participant in your group chose an effort level of 1 . Since the minimum effort in your group is 1 , the group project benefit is $\$$ $3,000(=\$ 3000 * 1)$ for each member. And as your own effort level is 2 , the cost of your effort that is subtracted from your earnings is $\$ 2000 * 2=\$ 4,000$. Therefore, your earnings will be $\$ 3,000+\$ 3,000$ - $\$ 4,000=\$ 2,000$, which is where the row of your effort level 2 intersects with the minimal effort column equal to 1 . 
- Suppose you choose an effort level 3 and the minimum level of effort of the group is 2 . This means that everyone in your group chose or 2 (like you) or 3 . Since the minimum effort in your group is 2 , the group project benefit is $\$ 6.000(=\$ 3,000 * 2)$ for each member. And as your own effort level is 3 , the cost of your effort that is subtracted from your earnings is $\$ 2000 * 3=\$ 6,000$. Therefore, your earnings will be $\$ 3,000+\$ 6,000-\$ 6,000=\$ 3,000$, which is where the row of your effort level 3 intersects with the minimal effort column equal to 2 .

Note that the more units of effort you choose is more costly for you but that the higher is the minimum effort, you and others in the group earn more.

Are there any questions?

After each group has completed the activity, it will be announced the minimum effort chosen in the group. Then we meet again in this room to finish today's activities. We will announce the number of cards MY TOKEN invested in the group account for the first and second round of the first activity. A coordinator will call you to answer a questionnaire. When you have completed the questionnaire, you will go with another coordinator to calculate the total earnings of the two activities and will receive your total earnings.

Are there any questions?

Are there any on this activity? Please do not talk to anyone about the exercise.

Now we will form three groups and announce which group each participant belongs to. From this moment onwards we ask you to remain silent.

Participants are allocated into groups according to the network score. The main coordinator will announce which group each participant is allocated to. There is a room assigned to each group with its assigned coordinator. Please ask participants to remain silent when they move to another room and during the experiment. The main coordinator keeps the group $C$.

Please remain silent when moving from one room to another and during activity.

Each coordinator in his/her group: Let's start the only round of this activity. A coordinator provides the YELLOW CARDS to each participant. Please make sure the player number matches with your player number. Please make your choice by marking an $\mathrm{X}$ on the level of effort you want to choose.

At this time, the coordinators give each participant the YELLOW DECISION SHEET according to their player number. Check whether the player number on the sheet is the same as the player number. Once participants have made their decision, the coordinators will collect the YELLOW CARDS in an envelope and find out the minimum effort in the group. These coordinators must fill out the MONITORS CALCULATION SHEET.

Important. When the yellow decision CARDS are collected the coordinator should check whether every participant made a decision.

Today's second exercise is finished. Now we will move back to a classroom where we participated in the first exercise.

Each coordinator announces the results ONLY for his//her group and then, groups gather in the main room. 
The lowest effort level chosen was, which means that if you decided one unit of effort, your earnings are ... if you decided 2 units of effort your earnings are ... and if you decided 3 units of effort, your earnings are ...

The main coordinator announces the results of the first activity. Participants are called to answer the survey and then receive their earnings.

We're going to calculate your earnings and we'll call you one by one. For the first exercise, we are going to announce the number of tokens that were invested in the group account in the two rounds.

Then the coordinator will announce the number of tokens that have been invested in the group account in the two rounds. Afterwards, two coordinators will go behind two desks to calculate each participant's earnings for each round and the final earnings of this exercise.

The number of tokens in the group account in the first round was ... in the second round was... This means, in terms of earnings, that in the first round, the group account has earned... ( $\$ 400 \mathrm{x}$ the number of tokens $=$ total amount); in the second round...

Now each one of you should wait until one of the coordinators calls your name to calculate your earnings and hand you the payment of today's activities. In the meantime, one coordinator will be calling you to ask you to answer a short questionnaire.

We strongly recommend you not to discuss today's activity with someone in next groups because activities for next groups may be different and thus participants in next groups might get confused by receiving incorrect information.

\section{viii. The post-game survey and Traditional measures of social capital}

In the survey we collected at the end of the session, there is a module on individual socio-economic characteristics (e.g. age and level of education), a module on household characteristics (e.g. income, assets, household size), a module on social capital measures, a module about FA (e.g. date of enrolment), a module about the game (e.g. whether the participant understood the game). The following are the different questions we used to build our traditional measures of social capital. 
Table A.7. Survey Social Capital measures

\begin{tabular}{|c|c|}
\hline Question & Variable \\
\hline \multicolumn{2}{|l|}{ Civic Participation } \\
\hline $\begin{array}{l}\text { Do you think that in this neighborhood there are opportunities to } \\
\text { participate and give an opinion on the decisions that affect most people? } \\
\text { If Yes, have you participated in these discussions? }\end{array}$ & $\begin{array}{l}\text { Participation in neighborhood } \\
\text { decisions }\end{array}$ \\
\hline $\begin{array}{l}\text { How often there have been meetings in the neighborhood to work out } \\
\text { problems in the community? For example, to discuss problems about the } \\
\text { streets, the school or cleaning the park. Have you or anyone from your } \\
\text { Household participated in these initiatives? }\end{array}$ & $\begin{array}{l}\text { Participation in the neighborhood } \\
\text { meetings }\end{array}$ \\
\hline $\begin{array}{l}\text { Do you actively participate in any of the following groups, associations } \\
\text { or organizations? }\end{array}$ & $\begin{array}{l}\text { Membership in at least one } \\
\text { organization }\end{array}$ \\
\hline If Yes, do you attend to the meetings? & \multirow{5}{*}{$\begin{array}{l}\text { If is member } \\
\text { of any civic } \\
\text { association }\end{array}$} \\
\hline If Yes, do you participate in the decision making processes? & \\
\hline If Yes, Are you one of the leaders in the organization? & \\
\hline If Yes, Do you support the organization with money or volunteer work? & \\
\hline If yes, how many hours do you spend in this organization monthly? & \\
\hline Humanitarian or charitable organization & \multirow[t]{2}{*}{ Bonding social capital } \\
\hline Church or religious organization & \\
\hline Volunteer work with the community organization & \multirow[t]{4}{*}{ Bridging social capital } \\
\hline Environmental organization & \\
\hline Ethnic organization & \\
\hline Sport or recreational or cultural organization & \\
\hline Education organization (i.e. parents association) & \multirow[t]{5}{*}{ Linking social capital } \\
\hline Community action [Accion comunal] association & \\
\hline Security organization & \\
\hline Labor Union, cooperative or professional organization & \\
\hline Political party & \\
\hline
\end{tabular}

\section{Voting behavior}

Did you vote in the last local elections in 2007 (Mayor, council, State, Voted in local elections (2007) Congress)?

Did you vote in the last presidential elections in $2006 ?$ Voted in presidential elections (2006)

\section{Trust and cooperation perception}

Generally speaking, would you say that most people in your community can be trusted, few people can be trusted or that you need to be very careful in dealing with people?

Would you say that most people in your community try to be helpful, they help only if others help or that they are just looking out for themselves?

\section{Altruism}

In the last 12 months, how food, money, clothes often do you help anyone (different from family) with any of the following (Always, usually, sometimes, rarely, never)... by offering your seat in the bus

Domestic work

Carrying a case, box, bag, package, groceries Child care or taking care of the animals, the plants or the house when the person is not present

\begin{tabular}{ll}
$\begin{array}{ll}\text { Trust: do you } \\
\text { consider that you } \\
\text { can trust in? }\end{array}$ & $\begin{array}{l}\text { Most people, } \\
\text { Few people, } \\
\text { None }\end{array}$ \\
$\begin{array}{ll}\text { Perception } \\
\text { within the }\end{array}$ & $\begin{array}{l}\text { Cooperation, } \\
\text { Reciprocity, Self- } \\
\text { community }\end{array}$ \\
\hline
\end{tabular}

Always or with money, food or usually, the clothes player has by offering her seat in helped the bus anyone... with domestic work by carrying a case, box, bag by taking care of the house or children 